\title{
INTERNAL CONTROL QUALITY AND INFORMATION ASYMMETRY IN THE SECONDARY LOAN MARKET
}

Dina El-Mahdy

Virginia Commonwealth University

Follow this and additional works at: https://scholarscompass.vcu.edu/etd

Part of the Business Commons

(C) The Author

\section{Downloaded from}

https://scholarscompass.vcu.edu/etd/224

This Dissertation is brought to you for free and open access by the Graduate School at VCU Scholars Compass. It has been accepted for inclusion in Theses and Dissertations by an authorized administrator of VCU Scholars Compass. For more information, please contact libcompass@vcu.edu. 


\title{
INTERNAL CONTROL QUALITY AND INFORMATION ASYMMETRY IN THE SECONDARY LOAN MARKET
}

A Dissertation submitted in partial fulfillment of the requirements for the degree of Doctor of Philosophy in Business at Virginia Commonwealth University

\author{
DINA F. EL-MAHDY \\ Virginia Commonwealth University \\ Richmond, Virginia \\ Master of Accounting and Finance, Cairo University, Egypt, 2004 \\ B.Com. (Honor), Cairo University, Egypt, 1997 \\ DISSERTATION COMMITTEE MEMBERSHIP \\ MYUNG SEOK PARK \\ Associate Professor of Accounting (Chair) \\ BENSON WIER \\ Professor of Accounting \\ CAROLYN STRAND NORMAN \\ Professor of Accounting \\ JONG EUN LEE \\ Assistant Professor of Accounting \\ MANU GUPTA \\ Assistant Professor of Finance \\ 오 Dina F. El-Mahdy, 2011 \\ All Rights Reserved \\ May 12, 2011
}




\section{ACKNOWLEDGEMENT}

I would like to deeply thank Dr. Myung Seok Park, my dissertation committee chair, for his support, time and efforts throughout my $\mathrm{PhD}$ journey. Dr. Park has made my graduate experience at VCU a memory that I will cherish forever. I am also grateful to my dissertation committee, Dr. Carolyn Strand Norman, Dr. Benson Wier, Dr. Jong Eun Lee, and Dr. Manu Gupta. Their positive feedback made my dissertation possible.

I am indebted to Dr. Allen S. lee, my mentor, for his advice, endless time, and support. Dr. Lee is one of the best teachers I have had in my life and I am very grateful for having him as my mentor. He inspired and influenced me in a way that not only will benefit my future career but also will influence my future students.

I am thankful to my family and friends for their patience, support and understanding. I too much appreciate the support from the Executive Councils of the Graduate Student Association at Virginia Commonwealth University as well as the Egyptian Student Association in North America. Special thanks to my wonderful eight years-old twin, Mohamed and Noureen, for being considerate to the demanding nature of my job and their endless love and support. 
To the Martyrs of the Egyptian Revolution 


\section{TABLE OF CONTENTS}

Page

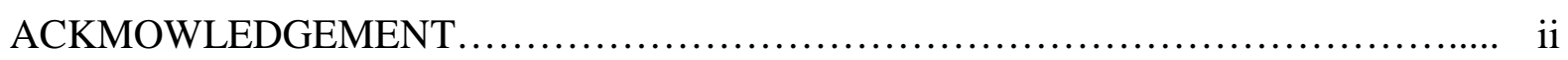

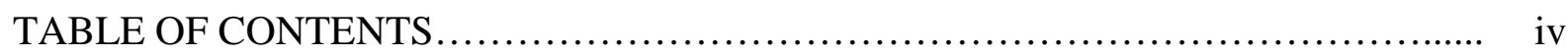

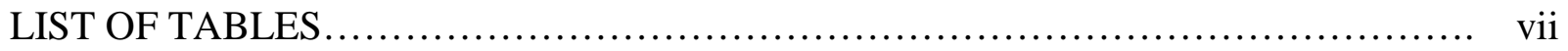

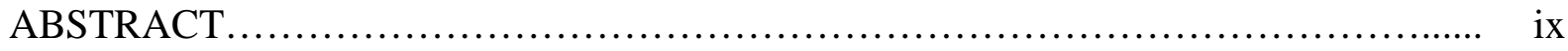

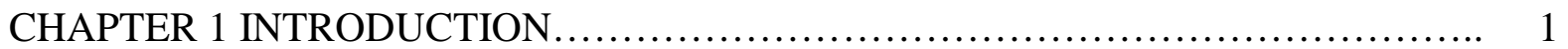

CHAPTER 2 INSTITUTIONAL BACKGROUND ............................... 14

2.1 Internal Control and Sarbanes - Oxley ACT of $2002 \ldots \ldots \ldots \ldots \ldots \ldots \ldots \ldots \ldots \ldots \ldots$

2.1.1 Internal Control over Financial Reporting........................... 14

2.1.2 SOX 2002 - Section 302: Voluntary Disclosure of ICDs.................. 15

2.1.3 SOX 2002 - Section 404: Mandatory Disclosure of ICMWs............... 17

2.2 Secondary Loan Market............................................. 20

CHAPTER 3 LITERATURE REVIEW ...................................... 25

3.1 Disclosure of ICFR................................................ 25

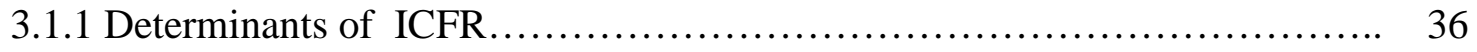

3.1.2 Characteristics of ICFR ......................................... 37

3.1.3 Consequences of ICFR........................................ 38

3.2 Information asymmetry in the Secondary Loan

Market........................................................................ 40

CHAPTER 4 HYPOTHESES DEVELOPMENT ............................... 44

4.1 Disclosure of IC quality and Information Asymmetry $\ldots \ldots \ldots \ldots \ldots \ldots \ldots \ldots \ldots . . . \ldots 4$

4.2 Types of IC Weaknesses and Information Asymmetry...................... 51 


\section{TABLE OF CONTENTS (Concluded)}

4.3 Remediation of IC Weaknesses and Information Asymmetry............... 54

4.4 The Moderating Effect of the Secondary Loan Market Characteristics on the Association between Information Asymmetry and ICDs...................... 55

CHAPTER 5 RESEARCH METHODOLOGY .................................... 59

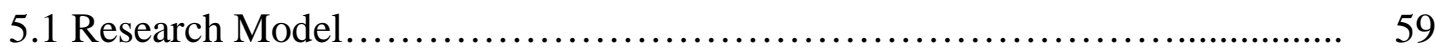

5.1.1 Dependent Variable............................................ 58

5.1.2 Independent Variable............................................. 60

5.1.3 Control variables............................................. 61

5.1.4 Empirical Models and Tests for Hypothesis.......................... 64

CHAPTER 6 EMPIRICAL RESULTS AND ANALYSIS....................... 69

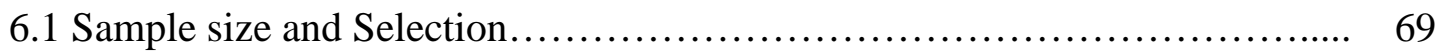

6.2 Descriptive Statistics............................................... 75

6.3 Univariate Analysis.................................................. 91

6.4 Results of Hypotheses................................................ 93

6.4.1 H1a: The effect of ICDs disclosure on Information Asymmetry........ 93

6.4.2 H1b: The effect of ICDs disclosure under Section 302 and Section 404 on Information Asymmetry....................................... 97

6.4.3 H2a: The effect of ICMWs disclosure on Information Asymmetry...... 100 


\section{TABLE OF CONTENTS (Concluded)}

Page

6.4.4 H2b: The effect of Company Level ICDs disclosure on Information

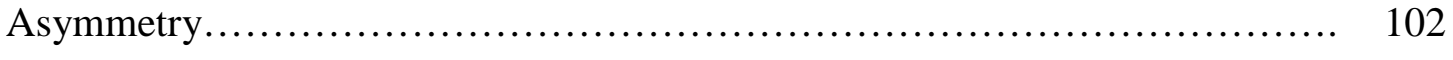

6.4.5 H3: The effect of IC Remediation on Information 105 Asymmetry...............

6.4.6 H4: The Moderating Effect of the Secondary Loan Market Characteristics on the Association between Information Asymmetry and ICDs.................

6.5 Additional Analyses: The Moderating Effect of the Secondary Loan Market Characteristics on the Association between Information Asymmetry and Severity of

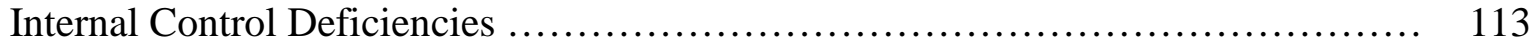

CHAPTER 7 SUMMARY AND CONCLUSION .............................. 118

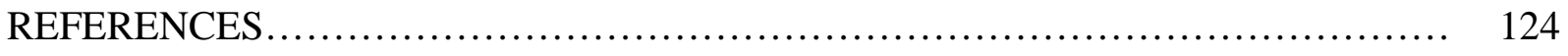

APPENDIX A............................................................... 131 


\section{LIST OF TABLES}

Table

Table Title

Page

No.

1 Research on the Association between Disclosure Quality and Cost of Capital

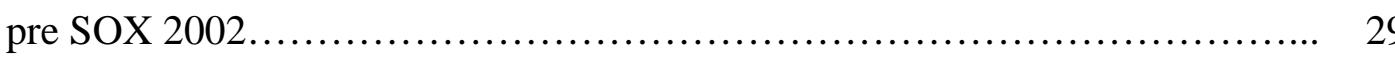

2 Research on the Disclosure of IC Quality post SOX 2002 - Section 302....... 30

3 Research on the Disclosure of IC Quality post SOX 2002 - Section 404....... 33

4 Research on the Disclosure of IC Quality on both Section 302 and Section $404 \quad 34$

5 Research on the Disclosure of IC Quality Post Section 404.................. 35

6 Final Sample..................................................... 73

7 Sample Distribution by Industry Type............................. 74

8 Descriptive Statistics............................................ 77

9 Descriptive Statistics by Year.................................... 82

10 Spearman Correlations Matrixes.................................... 85

11 Univariate Analysis............................................. 92

12 Regression of Information Asymmetry on Internal Control Deficiencies post

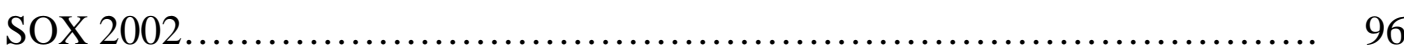

13 Regression of Information Asymmetry on Internal Control Deficiencies under

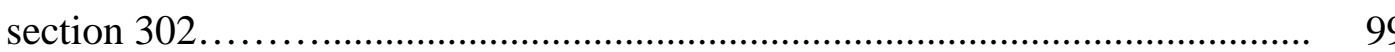

14 Regression of Information Asymmetry on Internal Control Material Weaknesses.

15 Regression of Information Asymmetry on Company-level Internal Control Deficiencies. 


\section{LIST OF TABLES (CONCLUDED)}

Table

Table Title

Page

No.

16 Regression of Information Asymmetry on Remediation of Internal Control

Deficiencies.

106

17 Regression of Information Asymmetry on the interaction term between ICDs and Number of Lenders (Syndication)

18 Regression of Information Asymmetry on the interaction term between ICDs and Credit Rating.

19 Regression of Information Asymmetry on the interaction term between ICDs and Debt Covenant.

20 Regression of Information Asymmetry on the interaction term between CL and Number of Lenders (Syndication)

21 Regression of Information Asymmetry on the interaction term between CL and Credit Rating.

22 Regression of Information Asymmetry on the interaction term between CL and Debt Covenants.

AP. A Variables Definition and Measurement..................................... 


\title{
ABSTRACT \\ INTERNAL CONTROL QUALITY AND INFORMATION ASYMMETRY IN THE SECONDARY LOAN MARKET
}

\author{
By: Dina F. El-Mahdy, Ph.D.
}

A Dissertation submitted in partial fulfillment of the requirements for the degree of Doctor of Philosophy in Business at Virginia Commonwealth University

Virginia Commonwealth University, 2011

Chair: Dr. Myung Seok Park Associate Professor of Accounting

There are four primary objectives of this study. First, it examines the association between the disclosure of the Internal Control Deficiencies (ICDs), as a proxy for the internal control quality, and information asymmetry (IA) in the secondary loan market. Second, it identifies which types of ICDs exacerbate conditions of information asymmetry in the secondary loan market. Third, it investigates whether firms that remediate or take corrective actions to address ICDs lead to a reduction in information asymmetry in the market. Finally, it examines the effect of the loan specific characteristics such as debt covenants, credit rating and number of lenders (syndication) in the secondary loan market on the association between ICDs and IA.

Results suggest that firms that disclose ICDs have significant positive association with IA and that ICDs reported under section 302 have significant positive association with IA. Although results on the association between the severity rank of ICDs by using Internal Control Material Weaknesses (ICMWs) as a proxy and IA are not supported, the use of Company Level (CL) 
internal control as a proxy for the severity rank of ICDs shows a significant positive association with IA. Overall, firms that remediate their ICDs have significant negative association with IA. Overall, there is a statistical negative association between the interaction term of ICDs and number of lenders (syndication) and IA. Same negative significant association is documented between the interaction term of ICDs and credit rating, and IA and the interaction term of ICDs and debt covenants and IA. The latter result suggests that the secondary loan market unique characteristics mitigate the negative consequences of the disclosure of ICDs and reduce the information asymmetry between lender and multiple arrangers. My results are consistent with prior studies' (Bryan and Lilien, 2005; Ge and McVay, 2005; Doyle, Ge and McVay 2007 a,b; Ashbaugh-Skaife, Collins, and Kinney, 2007, Ashbaugh-Skaife, Collins, Kinney, and LaFond, 2008), which suggest that firms with reported ICDs are generally small, poor performing, financially weaker, and characterized by higher market risk than firms with effective internal control system. 


\section{CHAPTER 1}

\section{INTRODUCTION}

Numerous studies document an association between characteristics of the firm's informational environment and information asymmetry among managers and investors in the equity market (Richardson, 2000; Frankel and Li, 2004; Schrand and Verrecchia, 2005; Bharath, Pasquariello, and Wu, 2008). For example, Frankel and Li (2004) find an association between the firm's future profitability measures (e.g., the informativeness of financial statements, analyst following, and news) and information asymmetry. In the same vein, Schrand and Verrecchia (2005) argue that the greater frequency of disclosure in the pre-Initial Public Offering (IPO) period is a tool that reduces adverse selection associated with the IPO issuance. However, few studies investigate the association, if any, between characteristics of the firm's informational environment and information asymmetry in the debt market, especially in the secondary loan market. ${ }^{1}$

Moreover, little research examines the impact of the quality of accounting information on the secondary loan market (Ball, Bushman, and Vasvari 2008; Yu 2007; Gaul and Uysal, 2009; Moerman, 2008). However, none of these existing studies examine the impact of the disclosure of Internal Control (hereafter IC) quality on information asymmetry in the secondary loan market. My study fills this gap in the literature by examining the association between the disclosure of IC effectiveness and information asymmetry in the secondary loan market.

IC is the cornerstone of business success. It assesses whether managers are receiving the relevant and correct information for decision making, assets are protected, and internal procedural laws and policies are followed by employees (Kinney, 2000). Additionally, the

\footnotetext{
${ }^{1}$ Secondary or syndicated loan market is relatively new in the US market. It is the place where the initial loan is sold by the primary lender (lead arranger) to multiple lenders (multiple arrangers).
} 
quality of a firm's IC system is a key element on the informativeness of the auditor's reported financial statements (Pae and Yoo, 2001). Internal control has, no doubt, a direct effect on the quality of financial reporting (Doyle, Ge and McVay, 2007b; Feng, Li and McVay, 2009). An ineffective internal control is thus a sign that information provided to management for its decision-making process contains errors and that assets are not protected. Considering that assets are the collateral in any loan agreement, if these assets are not protected, then collateral will be viewed by creditors as overvalued assets. Therefore, to the extent that assets are not protected in a firm, creditors must account for the high risk associated with their investment in such firms by increasing the cost of borrowing. Likewise, credit rating agencies might lower the credit rating of such risky firms.

The primary objective of this study is to examine the association between IC quality, ${ }^{2}$ as a proxy for the firm's informational environment, and information asymmetry in the secondary loan market. An effective IC system is defined as a quality system, whereas an ineffective system lacks quality. I examine the association between IC quality and information asymmetry for a sample of firms that extends from the Sarbanes - Oxley Act 2002 (hereafter SOX 2002) enactment date to the post section 404 reporting period. I then trace IC quality under SOX 2002 - section 404 (section 302) which represents the disclosure of audited (unaudited) IC weaknesses, and subsequent Auditing Standards provisions, such as Auditing Standard No.2 (hereafter AS2), which was amended later by Auditing Standard No. 5 (hereafter AS5). ${ }^{3}$ Additionally, I divide IC weaknesses into component elements to shed some light on the

\footnotetext{
${ }^{2}$ Quality of IC is disclosed under Sarbanes Oxley Act 2002 - IC related provisions to public registrants accompanying footnotes in various statutory filings such as: Item 9A of the Form 10-K, Item 4 of the Form 10-Q, and 8-K forms (Irving, 2006).

${ }^{3}$ Auditing Standard No. 5 was released to replace Auditing Standard No. 2 which was released to guide auditors in complying with SOX 2002 section 404. My sample period does not extend to the enactment date of AS5 (The fiscal years ending on or after November 15, 2007) and hence the analysis will be restricted to AS2.
} 
differential effects on information asymmetry in the secondary loan market. For example, IC weaknesses could occur on the company or account-specific level. IC weaknesses are also divided into three categories according to Auditing Standard No. 2. These three components are ordered in ranks of severity as: control deficiency, significant deficiency and material weaknesses.

Taken together, there are four primary objectives of this study. First, it examines the association between the disclosure of the Internal Control Deficiencies (ICDs), as a proxy for the internal control quality, and information asymmetry (IA) in the secondary loan market. Second, it identifies which types of ICDs exacerbate conditions of information asymmetry in the secondary loan market. Third, it investigates whether firms that remediate or take corrective actions to address ICDs lead to a reduction in information asymmetry in the market. Finally, it examines the effect of the loan specific characteristics such as debt covenants, credit rating and number of lenders (syndication) in the secondary loan market on the association between ICDs and IA.

I am motivated to study the association between IC quality and information asymmetry in the secondary loan market for a number of reasons. First, the secondary loan market is a vital and unique sector in the US economy. It offers unique information (e.g., the reputation of the syndication arranger, various types of loans with different maturities, purposes, and characteristics) not traditionally offered by the equity market (Moerman, 2008). More importantly, there are two types of traders in the secondary loan market, informed and uninformed traders. The informed traders usually have more information than that possessed by uninformed traders, potentially creating an adverse selection problem associated with such information asymmetry among traders. Information asymmetry therefore affects total demand 
and supply of information in the market, indicating an imperfect market (Angbazo, Mei and Saunders 1998; Richardson, 2000; Kim and Park, 2009). Moreover, the secondary loan market is a fast-growing and important sector in the US economy. It has been argued that the secondary loan market resulted in a revolution in the US market and lessened the impact of the recent financial crisis of 2007-2008 on the US economy. ${ }^{4}$ According to the Reuters Loan Pricing Corporation (LPC), the volume of the secondary loan market in the US grew from $\$ 8$ billion in 1991 and to $\$ 340$ billion in the second quarter of $2009 .^{5}$

Second, IC disclosures, unlike other types of disclosures, exist in complex settings under the IC provisions of SOX 2002. In general, the IC related provisions have been sharply criticized for being uniform across firms of different sizes, industries and complexities (Irving, 2006). Chief executives argue that the cost of compliance with SOX 404 has hindered IT installations, hiring, and product launches, as well as delayed strategic alliances (Irving, 2006). In 2003, the SEC estimated the cost of compliance per registrant at $\$ 91,000$; however, the actual compliance cost ranges from $\$ 5$ million for large firms to $\$ 1$ million for small firms (De Franco, Guan, and Lu, 2005). Additionally, IC disclosure under SOX 2002 - IC related provisions provides both unaudited-voluntary (section 302) and audited-mandatory (section 404) disclosure, each with its own unique structure related to varying degrees of uncertainty in the market.

Additionally, research on whether IC disclosure under these provisions adds value to the market is inconclusive. Moreover, sections 302 and 404 differ significantly in their requirements, as well as their impacts on the business environment. ${ }^{6}$ The cost (e.g., audit fees and SEC filing

\footnotetext{
${ }^{4}$ Press Release, Business Wire, November 4, 2004.

${ }^{5}$ LPC web page: http://www.loanpricing.com/analytics/pricing_service_volume1.htm

${ }^{6}$ Section 302 requires firms with internal control deficiencies to voluntary disclosure these deficiencies in their financial statement, while section 404 requires firms with material weakness to mandatory disclose these material
} 
that entails time and cost) associated with section 404 is far more than that of section 302. Hence, the investors' beliefs regarding the impact of IC provisions related to SOX 2002 are predicted to differ dramatically based on the two provisions. My study is motivated by this complex disclosure environment along with the mixed evidence on the usefulness of SOX 2002 - IC related provisions to the US market, especially in the secondary loan market. In an attempt to measure the net economic benefits of SOX 2002 -IC related provisions to the market, I use the bid-ask spread as a net measure of the economic benefits of SOX 2002 in a new paradigm that tests the association between the quality of Internal Control over Financial Reporting (hereafter ICFR) and information asymmetry in the secondary loan market.

Third, I am motivated by the mixed evidence on the association between disclosure as a proxy for information asymmetry and its effect on the cost of capital. Studies on the determinants of internal control material weakness show that firms with material weaknesses are more likely to be small, financially weak, still growing or young, have poor earnings quality such as abnormal accruals, high cost of equity capital, complex operations, and/or are undergoing restructuring such as mergers and acquisitions (Doyle, Ge and McVay 2007 a, b; AshbaughSkaife, Collins, and Kinney, 2007, Ashbaugh-Skaife, Collins, Kinney, and LaFond, 2008). Nevertheless, research on the impact of the quality of internal control on the cost of capital provides mixed results. For example, Ashbaugh-Skaife, Collins, Kinney, and LaFond (2009) find a positive association between the cost of capital and disclosure of material weaknesses under sections 302 and section 404. In the same vein, Ogneva, Subramanyam, and Raghunandan (2007) found no association under section 404. Botosan (1997) also finds no relation between

weaknesses in their financial statements. Additionally, section 404 requires an external auditor's attestation on the management assessment of the material weaknesses disclosed and discovered. Moreover, Bedard (2006) finds that the magnitude of earnings manipulations reported under section 302 is double that reported under section 404. 
disclosure and the cost of capital in the pre-SOX 2002 period. One possible interpretation of these mixed results is that the cost of capital does not always synchronize with the welfare of current or prospective investors (Gao, 2010). The cost of capital has varying impacts on different types of traders, and this impact is conditional on investor's risk attitude and adjustment costs of new investments $(\mathrm{Gao}, 2010){ }^{7}$ The disclosure of Internal Control Deficiencies increases the level of risk that traders are willing to assume. Disclosed weaknesses increase the level of uncertainty regarding the firm's operations as well as the confidence in the reliability of financial statements and hence collateral. Therefore, traders increase the interest rate for firms with Internal Control Deficiencies relative to their counterparts without evident weaknesses in the IC.

Fourth, I am motivated by the negative contagious effects ${ }^{8}$ of IC weaknesses on rival firms. Although the market value of firms with reported material weaknesses is only $1.28 \%$ of the market value of S\&P 500 firms (Bryan and Lilien, 2005), their effects, both negative and positive are more significant than they may seem at first. Potentially, the consequences of a deficient internal control system to the economy are immeasurable. For example, earnings restatements ${ }^{9}$ due to the presence of severe IC errors convey bad news about the restated and non-restated (rival) firms to the market and cause a decline in share prices of rival, non-restating firms (Gleason, Jenkins, and Johnson, 2008). Moreover, restating firms experience reputational penalties to the extent that $60 \%$ of the restating firms have experienced top management turnover (either Chairman, CEO or president) within two years of the announcement of the restatements

\footnotetext{
${ }^{7}$ Adjustment costs of new investment can be defined as the decrease in the stock returns due to the instantaneous initiation of new investments.

${ }^{8}$ The contagious effect is the negative consequences of a firm on other rival firms in the industry.

${ }^{9}$ Earnings restatement and corporate fraud have increased dramatically over the last three decades (Desai, Hogan, and Wilkins, 2006) to the extent that the continuous increase in the accounting restatement triggers the issuance of reforms and business regulations such as Sarbanes Oxley Act 2002 (SOX 2002 hereafter) and the establishment of institutions such as Public Company Accounting Oversight Board (PCAOB).
} 
(Desai, Hogan, and Wilkins, 2006). On the other hand, the expected impact of the quality of internal controls to the U.S. market is a reduction in the cost of capital and better access to a capital market (Bryan and Lilien, 2005). In a related study, Ashbaugh-Skaife, Collins, Kinney, and Lafond (2008) find that firms that improved internal control, as evidenced by going from adverse to unqualified SOX 404 opinions, show a significant increase in accrual quality, and hence an improvement in the quality of their financial statements.

In summary, I am motivated by the importance of SOX 2002 - section 302 and section 404 in addition to AS2 and AS5. SOX 2002 - section 404 is one of the most puzzling, yet important provisions in the capital market. I am also motivated by the fast growth of the U.S. secondary loan market in a relatively short period of time and the implications of information asymmetry that has an invariable negative impact on market efficiency (Richardson, 2000; Kim and Park, 2009).

Verrecchia (2001) argues that information asymmetry is a decreasing function of a comprehensive theory of disclosure. Additionally, anecdotal evidence suggests that high disclosure quality increases the firm's visibility, reduces the cost of processing public information and, thus, increases the trading volume by uninformed traders (Brown and Hillegiest, 2007). Expectedly, increased trading by uninformed traders reduces information asymmetry between informed and uninformed traders. In the same vein, Leuz and Verrecchia (2000) argue that more disclosure, most likely voluntary, diminishes the portion of information asymmetry related to the firm's cost of capital.

My study contributes to literature on internal controls over financial reporting as well as on information asymmetry in the secondary loan market. First, I build on the ongoing, yet unresolved, debate on the usefulness of SOX 2002 to the firm and business environment in a 
number of ways. To the best of my knowledge, my study is the first to integrate the quality of IC and information asymmetry in the secondary loan market into one paradigm. For example, my study differs from and extends the study by Beneish, Billings and Hodder (2008). I use contemporaneous analysis that is based on testing the disclosure of weaknesses and information asymmetry after controlling for firm, lender, and loan characteristics. Hence, one of the contributions of this study is the use of association studies relative to event study methodology used by Beneish, Billings and Hodder (2008). My study extends the limited research on the association between internal control quality and cost of equity by focusing on the cost of borrowing as a component of the cost of capital.

Second, my study also extends research on audit quality (DeAngelo, 1981, Teoh and Wong, 1993, Krishnan, 2005) because I compare two SOX 2002 provisions, section 302 (unaudited disclosure of Internal Control Deficiencies) and section 404 (audited disclosure). I would expect auditing to have a positive influence on the secondary loan market. My study also extends the study made by Moerman (2008) who found that timely loss recognition, as a measure of financial reporting quality, decreases information asymmetry in the secondary loan market. Furthermore, my study extends the work by Ashbaugh-Skaife, Collins, Kinney, and Lafond (2009), which argues that firms that failed to remediate their Internal Control Deficiencies $(\mathrm{ICDs})^{10}$ receive an adverse SOX 404 opinion for the period after the ICDs disclosure and consequently experienced a higher cost of equity capital. Moreover, my study contributes to resolving the mixed evidence on the association between disclosure of material weaknesses and the cost of capital. For example, Ashbaugh-Skaife, Collins, Kinney, and LaFond (2009) find a positive association between the cost of capital and disclosure of material weaknesses under

\footnotetext{
${ }^{10}$ Significant deficiencies and material weaknesses are referred to as Internal Control Deficiencies (ICDs) in prior literature (Leone, 2007).
} 
sections 302 and section 404. However, Ogneva, Subramanyam, and Raghunandan (2007) do not find such an association under section 404.

Third, I examine the relationship between the severity of internal control and information asymmetry in the secondary loan market. Raghunandan and Rama (2006), Doyle, Ge and McVay (2007b), and Hoitash, Hoitash, and Bedard (2009) stratify internal control problems into general and account specific. General internal control problems include (control environment, employee competence/triaging, and period-end procedures). Account-specific control issues are those that affect a narrow activity in the internal control system, such as account specific balances (e.g., inventory, accounts payable, accounts receivable). Raghunandan and Rama (2006) did not find a significant association between the severity of Internal Control Deficiencies and audit fees. However, Doyle, Ge and McVay (2007b) find a significant association between severity of internal control (general problems) and accrual quality.

In building my theoretical hypotheses, I focus on four main predictions: (1) the association between IC disclosure and information asymmetry, (2) types of IC weaknesses and information asymmetry, (3) IC remediation and information asymmetry, and (4) the effect of the interaction term between loan-sp=ecific characteristics and IC weaknesses on information asymmetry. Throughout these predictions, I compare effects across section 302 (voluntary disclosure of IC) and section 404 (mandatory disclosure of IC). Prior research documents many benefits from providing more disclosure to various stakeholders. For example, disclosure results in lower information asymmetry and estimation risk (Lang and Lundholm, 1996; Welker, 1995; Schrand and Verrecchia, 2005), lower underpricing (Schrand and Verrecchia, 2005), lower cost of private debt (Mazumdar and Sengupta, 2005), and lower cost of capital (Botosan 1997; Sengupta 1998; Botosan and Plumlee 2002). Moreover, Easley and O'Hara (2004) suggest that 
the composition of information (private versus public information) affects the cost of capital. They argue that private information increases the cost of capital because private information triggers more demand on stock returns. Based on prior research, I first predict that disclosure of bad news such as the Internal Control Deficiencies will increase information asymmetry. Having two types of disclosure, mandatory versus voluntary, under SOX 2002, I predict that information asymmetry will be lower under section 404 than under section 302 due to the uncertainty surrounding the IC disclosure under section 302 (Beneish, Billings and Hodder 2008).

Moreover, disclosure of IC quality is dependent on the internal systems of the firm. Hammersley, Myers, and Shakespeare (2008) find that the information content of the disclosure of Internal Control Deficiencies depends on the severity of the Internal Control Deficiencies. Disclosure of IC quality signals to the market on the corporate governance and oversight roles of the Board of Directors (Krishnan, 2005). Moreover, Irving (2006) argues that "An effective system of internal controls protects the integrity of transactions recorded as inputs to the financial reporting system and aggregated into financial reports." Disclosure of ineffective ICs affects past, present and future financial reporting (Irving, 2006) providing information to internal managers and market-wide participants for decision-making purposes such as buying and selling decisions, ratings by credit agencies, loan decisions, and rating firm creditworthiness.

When a weakness in the internal control system is disclosed to the public, it increases uncertainty about the firm's internal operations and activities (Beneish, Billings and Hodder 2008). Weakness is symptomatic of increased business risk (Ogneva, Subramanyam, and Raghunandan, 2007). Additionally, uncertainty increases the demand for risk-taking actions by investors and traders. Hence, informed traders in the secondary loan market will demand more private information about unsecured collateral and increase the cost of borrowing to the firm 
relative to that cost demanded by informed traders. Uninformed traders might withdraw totally from the market in the presence of high uncertainty, or when the cost of acquiring information is very high (Lev, 1988).

Taken together, severe information asymmetry increases the demand for information by informed traders and the possibility that uninformed traders will leave the market. The disclosure of material weaknesses (as a severe type of IC weaknesses) may also lead banks and short-term lenders to discount the collateral potential of the borrowing firms' financial assets (Gupta and Nayar, 2006) and trigger a lower debt rating, thus increasing the probability of default and/or higher borrowing costs (Moody's Investor Service, 2004; Fitch Rating, 2005), and increase market uncertainty (Beneish, Billings and Hodder 2008; Kim and Park 2009). I expect various types of IC weaknesses to have varying impacts on information asymmetry in the secondary loan market. I will stratify IC weaknesses by type and investigate their relationship to information asymmetry in the secondary loan market. Doyle, Ge and McVay (2007a) suggest that the determinants of material Internal Control Deficiencies vary according to the reasons for those weaknesses.

In other words, each firm has its own unique set of internal control features. Also, results suggest that firms that report account-specific weaknesses tend to be larger, older, financially healthier, have more complex and diversified business operations and are growing more rapidly than firms that report company-level weaknesses. Likewise, firms with company-wide problems do not have either the resources or the experience to maintain a good control system. Moreover, the type of material weaknesses differs in terms of audit delay (Ettredge, Li and Sun, 2006). For example, internal control general weaknesses in personnel, processes, and procedures are associated with longer audit delays than those related to account-specific weaknesses. Therefore, 
I expect to find higher information asymmetry in the presence of more severe weaknesses relative to that associated with less severe IC weaknesses.

Effective internal controls enhance the quality of financial reporting and reduce agency cost (Haron, Ibrahim, Jeyaraman, and Chye, 2010). Moreover, effective internal control provides the "quality assurance" expected by management and various stakeholders to assure that firm objectives are being achieved (Kinney, 2000). Therefore, the disclosure of effective internal control is assumed to reduce stakeholder's uncertainty. Likewise, disclosure of remediation actions taken by the management to correct IC weaknesses is expected to reduce information asymmetry.

Low quality internal control, as measured by ineffective IC, increases information asymmetry for lenders and between borrowers and lenders and creates an adverse selection problem, the inability of traders to differentiate among the quality of loans. I measure ineffective internal control by the presence of Internal Control Material Weaknesses (hereafter ICMWs) post-section 404 and Internal Control Deficiency (hereafter ICD) pre-section 404 and postsection 302. I measure ineffective IC using both level and change (remediation) in IC weaknesses. The level of ineffective IC will be operationalized by the different types of IC weaknesses in terms of severity (e.g., control deficiency, significant deficiency or material weaknesses or company-level versus account-specific weaknesses). The change in IC weaknesses will be measured by whether firms took remediation actions to correct these weaknesses.

I predict different levels of information asymmetry as a result of the disclosure of IC weaknesses under different SOX 2002 - IC related provisions. For example, section 302, unlike section 404, does not require the auditing attestation on the management assessment of IC. 
Additionally, AS2 does not provide clear guidelines on the amount and extent of ineffective IC that should be disclosed. Therefore, I conjecture that disclosure of IC weaknesses under section 302 is characterized by higher uncertainty than that associated with those under section 404 . Moreover, higher uncertainty under section 302 triggers more demand from informed traders for private information and hence, higher information asymmetry is expected under section 302 than that under section 404. Finally, I use the unique characteristics of the secondary loan market such as debt covenants, credit rating and number of lenders to explain the hypothesized relationship between the information asymmetry and the disclosure of Internal Control Deficiencies.

The remainder of this dissertation is structured as follows. In chapter two, I introduce an institutional background on internal controls and financial reporting as well as the secondary loan market. I discuss the literature on the disclosure of internal controls and information asymmetry in the secondary loan market in chapter three. I develop the hypotheses and present the research methodology in chapters four and five, respectively. I discuss the findings and empirical evidence is chapter six. In chapter seven, I summarize the results of this study. 


\section{CHAPTER 2}

\section{INSTITUTIONAL BACKGROUND}

\subsection{Internal Control and Sarbanes - Oxley ACT of 2002}

\subsubsection{Internal Control over Financial Reporting}

The Committee of Sponsoring Organizations of the Treadway Commission (COSO 1992) defines internal control as: "a process, effected by an entity's board of directors, management and other personnel designed to provide reasonable assurance regarding the achievement of objectives in the following categories: effectiveness and efficiency of operations, reliability of financial information, and compliance with the applicable laws and regulations." The main purpose of maintaining internal control systems is thus to prevent, detect, and eliminate irregularities and fraud in financial reporting (Yu and Neter, 1973). Hence, the internal control system is the proactive method by which a firm can detect fraud and intentional and unintentional errors. By definition, there is no alternative method to prevent material errors and fraud other than maintaining an effective internal control system. Thus, failure to detect material weaknesses in internal controls can affect many users of financial reporting including, but not limited to, employees, regulators, investors, and creditors. Hence, such failures could result in misleading the market-wide participants or market imperfection.

Evaluating the effectiveness of internal control systems has always been part of audit tasks. Auditors, according to the AICPA, are required to evaluate the reliability of internal control in order to determine the scope and nature of audit processes. In the pre- SOX 2002 era, there were no specific objective guidelines for auditors to follow in evaluating the reliability of internal control systems. Traditionally, while evaluating the effectiveness of internal control systems, auditors were making a trade-off between sample size and precision limits. Most 
methods used were subjective and qualitative such as flowcharts (Yu and Neter, 1973). Moreover, the evaluation of internal control systems was characterized as biased and inaccurate. Further, these evaluations were described as lacking uniformity and consistency (Corless, 1972).

The history of IC systems shows that government regulations required companies to establish systems of internal control as early as 1977 (Byington and Christensen, 2005; Ge and McVay, 2005). However, statutory regulations that govern the disclosure of internal controls over financial reporting have not been clear to SEC registrants and in most cases were not "cost effective" in terms of the net benefit of these statutory regulations to the U.S. firm. The Foreign Corrupt Practices Act (FCPA) of 1977 was the first law which required internal control disclosure. The FCPA required public firms to disclose internal control deficiencies when announcing a change in auditors (Irving, 2006). It also required firms to maintain "cost effective" systems of internal controls over financial reporting. However, the term "cost effective" was quite vague to registrants and subject to interpretation.

\subsubsection{SOX 2002 - Section 302: Voluntary Disclosure of ICDs}

Corporate governance failures by the onset of the 1990s reinvigorated the need for corporate reforms to address fraud. Therefore, SOX 2002 was enacted on July 30, 2002 to curb business fraud and corruption. SOX 2002 was named after Senator Paul Sarbanes (a Democratic senator from Maryland) and Representative Michael Oxley (a Republican congressman from Ohio). One of the key elements to blame for corporate fraud is the internal control deficiencies that failed to detect those frauds. Therefore, SOX 2002 - section 302 was issued followed by section 404, AS2, ${ }^{11}$ and AS5. ${ }^{12}$ The main purpose of the SOX 2002 - IC related provisions is to

\footnotetext{
${ }^{11}$ The PCAOB issued the Auditing Standard No. 2: "An Audit of Internal Control over Financial Reporting Performed in Conjunction with an Audit of Financial Statements". Auditing Standard No. 2 was issued following the issuance of SOX 2002 - section 404 to assist auditors in issuing an opinion on the effectiveness of their public company clients' internal control. Over 200 pages, Auditing Standard No. 2 provides new detailed responsibilities
} 
inform investors and various stakeholders about weaknesses in the IC structure of the firm. Prior to IC disclosures (section 302 and section 404) related to SOX 2002, disclosure of internal control was only required when changing auditors (Haron, Ibrahim, Jeyaraman, and Chye, 2010). SOX 2002 - Section 302 requires the CEO and CFO to certify that the financial reports are free from material errors and weaknesses. Section 302 became effective on August 29, 2002. SOX 2002 - Section 906 "White-Collar Crime Penalty Enhancements" further stipulates the criminal penalties against firms' financial officers who knowingly certify incorrect financial statements. Section 302 requires voluntary disclosure of ICDs as well as management evaluation of the effectiveness of controls and procedures. However, section 302 was not clear to either management or auditors. Management could not find clear guidelines on how to evaluate the effectiveness of internal controls. Auditors were confused regarding whether to report the assessment of internal control systems to shareholders and/or management. Also, under section 302, no independent audit evaluation of a firm's internal controls was required. Therefore, managers had more discretion to disclose ICD pre-SOX 404.

There is a significant difference between voluntary and mandatory disclosures. To the extent that managers may be hesitant to report material weaknesses under section 302 due to the proprietary costs associated with full disclosure, I argue that section 302 is associated with discretionary managerial behavior, while section 404 is associated with intentional or

and extensive procedures on both auditors and their clients (public firms). It further differentiates between the external auditors' and management's responsibilities regarding evaluating and reporting internal control material weaknesses.

${ }^{12}$ In almost 118 pages and following the unintended cost and consequences of section 404 to the U.S. firm, the PCAOB released Auditing Standard No. 5: "An Audit of Internal Control Over Financial Reporting That Is Integrated with An Audit of Financial Statements, as well as an independence rule and conforming amendments to the Board's auditing standards" to amend the previously issued Auditing Standard No. 2. Auditing Standard No. 5 is issued to provide additional clarity, direct the external auditors' focus on the most important matters in auditing the internal control over financial reporting, and further eliminate unnecessary audit work previously stipulated by Auditing Standard No. 2. 
unintentional errors caused by inherent internal control risk. Additionally, voluntary disclosure might be seen as general disclosure that would exceed the minimum required disclosure (Haron, Ibrahim, Jeyaraman, and Chye, 2010).

However, mandatory disclosure can be seen as the minimum required disclosure. Intuitively, voluntary or general disclosure may or may not reduce uncertainty, but in all cases it is an indication of the company's willingness to reduce information asymmetry. Conversely, mandatory or minimum disclosure is, to some extent, more credible than voluntary disclosure. Mandatory disclosure is assumed to reduce uncertainty about the firm's internal operations and controls more than that associated with voluntary disclosure.

Business firms, once again, faced the same confusion they faced under FCPA 1977 with regard to the issuance and enactment of section 302. Under section 302, the Public Company Accounting Oversight Board (hereafter PCAOB) requires firms to report on the effectiveness of internal control over financial reporting. However, section 302 did not give clear guidelines to either management or external auditors on what, how, and when to report the internal control material weaknesses.

\subsubsection{SOX 2002 - Section 404: Mandatory Disclosure of ICMWs}

Preliminary discussions about Section 404 were initially raised by the Committee of Sponsoring Organizations (COSO) of the Treadway Commission in 1992 that recommended public firms report on the effectiveness of internal control over financial reporting in their annual reports. Section 404 became effective on or after November 15, 2004 for only accelerated filers and domestic firms with a market capitalization of $\$ 75$ million or greater. Under section 404, auditors are required to opine on the management assessment of internal control over financial reporting and further disclose the material weaknesses and issue an adverse opinion even if s/he 
finds material Internal Control Deficiencies. SOX 404 requires public firms to file forms $10-\mathrm{K}$ and 10-Q containing an evaluation by management of its internal control. It also requires the external auditors to provide an opinion regarding the management assessment of the internal control on an annual basis.

An excerpt of KRISPY KREME DOUGHNUTS INC ${ }^{13}$ Annual Report on Form 10-K Filing discloses the status of the firm's IC weaknesses as follows:

"The Company believes that, because of the number and magnitude of the restatement adjustments identified to date, it is highly likely that it will conclude that there were one or more material weaknesses in the Company's internal control over financial reporting at January 30, 2005. If the Company's management concludes that one or more material weaknesses existed, it will be unable to conclude that the Company maintained effective internal control over financial reporting as of January 30, 2005. Also, if one or more material weaknesses existed, the Company's independent registered public accounting firm will issue an adverse opinion with respect to the effectiveness of the Company's internal control over financial reporting as of January 30, 2005”.

Section 404 was different from section 302 in terms of its consequences to the firm. Engel, Hayes, and Wang (2007) find that section 404 has increased the frequency with which firms are going private to avoid the costly consequences of being a public firm. Following the issuance of section 404, the SEC established PCAOB to provide oversight for the implementation of section 404. Subsequently, the PCAOB issued AS2 followed by AS5: "An Audit of Internal Control over Financial Reporting Performed in Conjunction with an Audit of Financial Statements" establishing the rules for auditor attestation of firms' internal controls.

Therefore, SOX 404 imposes a burden on SEC registrants and carries costs and benefits to the U.S. firm. Section 404 has thus been named the section of unintended consequences (Gupta and Nayar, 2006). Opponents of section 404 argue that it does not benefit smaller firms.

\footnotetext{
${ }^{13}$ This excerpt is available at the company's web page: http://investor.krispykreme.com/releasedetail.cfm?ReleaseID=339854
} 
Therefore, the SEC in 2006 made recommendations to the PCAOB to exempt micro-cap firms (firms with market cap below $\$ 128$ million) from section 404 and small-cap firms (firms with market cap between $\$ 128$ and $\$ 787$ million) from the external auditor attestation on the management's decision on the quality of internal control (Ettredge, Li and Sun, 2006). Moreover, section 404 imposes substantial cost to large-size firms. In 2003, the initial estimation by the SEC of the financial burden associated with section 404 was approximately $(\$ 91,000)$ per firm (Bedard, 2006). However, the actual financial burden of implementing section 404 during its first year was $\$ 1,241,000(\$ 8,510,000)$ for firms with market capitalization between $\$ 75$ and $\$ 700$ million (more than $\$ 700$ million).

Therefore, section 404 was one of the most controversial, yet important, provisions under SOX 2002. Section 404 also includes the cost of gaining the attention of top management to make a decision regarding an internal operational activity such as internal control effectiveness (Bryan and Lilien, 2005). Section 404 constitutes a challenge to external auditors; therefore, Byington and Christensen (2005) provide checklists of tasks to make the auditor attestation and management assertions on the effectiveness of internal control under section 404 easier. The framework of suggested checklists includes management considerations and auditing considerations, in addition to considerations related to the use of spreadsheets, outsourcing and computer security.

In summary, voluntary disclosure of internal control quality under section 302 provides more detailed information than that provided by mandatory disclosure under section 404 . Under section 302, firms disclose ICD which incorporates both material weaknesses and significant deficiencies. However, under section 404, firms disclose only material weaknesses. 
There could be some incremental value of disclosing ICD over only disclosing material weaknesses. ICD include both material weaknesses and significant deficiencies. Disclosing a significant deficiency causes heterogeneity in stakeholders' beliefs in two ways. First, stakeholders might perceive a significant deficiency as negative, since it may develop into a material weakness in the future. Second, stakeholders might perceive a significant deficiency as positive and expect firms to take remediation actions in the future. Therefore, ICD may signal to the market the prospective risk associated with investing in ICD firms. I predict that disclosure of internal control quality under SOX 302 is incomplete due to the voluntary disclosure associated with it. Incomplete disclosure hence leads investors and creditors to search for private information in an effort to reduce information asymmetry. Also, voluntary disclosure is often less credible than mandated disclosure. The vagueness associated with voluntary disclosures helps in creating and increasing information asymmetry.

\subsection{The Secondary Loan Market}

In the Secondary loan market, initial loans are sold to multiple lenders by primary lenders. All lenders maintain a copy of the documentation of the borrower because each syndicate lender has a separate claim on the loan although there is only one loan contract. The basic structure of the syndicated loan contains the borrower (e.g., corporation), lead banks or lead arrangers, and the follower.

The historical development of syndicated lending can be divided into three phases (Gadanecz, 2004). The first phase features the emergence of syndicate lending in the 1970s as an autonomous business that replaced bilateral lending. Phase two started in the 1980s and was characterized by financial difficulties by many emerging market borrowers. Phase two triggered 
a restructuring of syndicate lending into bond financing. Phase three began in the 1990s and it was characterized by the revival of syndicated loans as an important sector in the US economy.

The two types of underwriting that are used in the syndicated lending are best efforts and firm commitment. Under best efforts, the lead bank does not guarantee the entire loan, and the borrower and lead bank can cancel the loan at anytime. This type of underwriting is used by less active banks. In contrast, under the firm commitment type of underwriting, the lead bank guarantees the entire loan, and it can be used in active markets in which mergers and acquisitions are more frequent.

In the secondary market for syndicated loans, loans are syndicated as an assignment or participation loan. The key difference between assignment and participation can be summarized as follows. In the secondary market assignment, the contract is between the borrower and the loan buyer. In the secondary market participation, the contract is between the original lender and loan buyer. Stated differently, for participation, the buyer participates in the existing loan's commitment, but the original lender remains the primary holder of the loan (Moerman, 2008). In the secondary market assignment, the sale is between two syndicate members or between one syndicate member and a bank outside the syndicate, while in secondary market participation, the borrower is a participant in the loan and, hence the contract does not change.

Syndicated lending benefits both the lenders and the borrowers. For borrowers, syndicated loans give them access to capital and are more flexible than borrowing from one lender. Syndicated lending is cheaper for borrowers. Lenders benefit because they can easily transfer the risk of the loan by syndicating it to multiple lenders. Syndicated loans are also attractive to junior lenders because they can easily syndicate the loans to senior lenders (Gadanecz, 2004). 
Syndicated loans in the secondary loan market are an important and unique sector in the US economy. Syndicated loans diversify credit risk and facilitate geographic and institutional sharing of risk for banks or multiple lenders (Gadanecz, 2004). Syndicated lending avoids the costs associated with bonds issuance, disclosure and marketing fees. The syndicated loan market is growing rapidly. In 2004, a study by the New Milken Institute states that: "The development of the syndicated loan market has led to a "quiet revolution" in America's capital market and has allowed the U.S. economy to avoid a damaging credit crunch during the last recession."14 According to the trading survey of Reuters Loan Pricing Corporation (LPC), the volume of the secondary loan market in the U.S. grew from $\$ 8$ billion in 1991 to $\$ 340$ billion in the second quarter of $2009 .{ }^{15}$ Hence, information asymmetry arising in the secondary loan market is expected to impact a wide sector of the U.S. economy. Almost $\$ 1$ trillion in syndicated loans are contracted annually (Sufi, 2007). Syndicated lending offers a wide array of information (e.g., the reputation of the arranger of the syndication, various types of loans with different maturities, purposes, and characteristics) not traditionally offered in the equity market (Moerman, 2008).

The secondary loan market features two types of traders: informed and uninformed traders. The informed traders usually have more information than that possessed by uninformed traders, creating an adverse selection problem. Adverse selection is a situation where buyers and sellers have different information about the same product. Stated differently, information asymmetry arises mainly from private information held only by informed traders. Managers might have a news release of private information (e.g., production/investment decisions) from which they hope to profit as they know something uninformed traders cannot know. For

\footnotetext{
${ }^{14}$ Press Release, Business Wire, November 4, 2004.

15 LPC web page: $\underline{\text { http://www.loanpricing.com/analytics/pricing_service_volume1.htm }}$
} 
example, Aboody and Lev (2000) contend that R\&D investments create information asymmetry. They find that insiders with knowledge of their firm's R\&D expenditures may profit from this private information.

Information asymmetry in the syndicated loan market arises from the differential information accessed by lead arrangers versus other multiple lenders. To the extent that the loan is risky, the lead arranger will retain a small portion of the loan and syndicate the remainder in the secondary loan market, thereby reducing their exposure to the risk. The information asymmetry in the secondary loan market thereby affects the total demand and supply of loans in the market. Prior research indicates this evident information asymmetry is a sign of market imperfection (Richardson, 2000; Kim and Park, 2009; Angbazo, Mei and Saunders 1998).

Syndicated loans are also subject to numerous financial restrictions including financial debt covenants that stipulate certain restrictions on the management. Moreover, informed traders in the secondary loan market such as lead arrangers and syndicate participants usually have access to specific borrower information such as monthly disclosure, covenant compliance, financial projections and future plans (mergers and acquisitions). The lead arranger also has superior privilege over other syndicate arrangers such as: a priority to other claims on the firms' assets, and imposed restrictive covenants on the firm (Moerman, 2008; Allen and Gottesman 2006). Information asymmetry of this nature affects the loan value, interest rates, maturities, covenants and other aspects of the contract. Moreover, high information asymmetry, as measured by the bid-ask spread, is an indication of market imperfection (Angbazo, Mei and Saunders 1998).

There is little limited research that directly tests the association between information asymmetry and accounting information in the secondary loan market. For example, Ball, 
Bushman, and Vasvari (2008) argue that the proportion of the loan that is held by the lead arranger is dependent on the increasing adverse selection and moral hazard problems created by the information asymmetry. They hypothesize that the content of the financial information in the financial statements mitigates the information asymmetry, thus minimizing the adverse selection and moral hazard problems. Therefore, they conclude that the lead arranger may choose to hold a larger proportion of the loan.

Likewise, Yu (2007) argues that concurrent research streams on the informational advantage of banks lack the direct test of banks' ex ante information advantage before loans are granted. Therefore, he tests the informational advantage of banks in the initiation stage of loans and investigates whether banks incorporate future earnings in evaluating the borrowers' financial situation. He finds that loan spreads are more sensitive to negative unexpected earnings than to positive unexpected earnings. This result is consistent with the contention that banks incorporate future earnings in valuing the borrowers' financial situation. Moreover, $\mathrm{Yu}$ finds that loan spreads are less sensitive to unexpected earnings for firms with high analyst followings and secured loans. He also finds that loan spreads are more sensitive to unexpected earnings for firms with income-increasing abnormal accruals and after the Regulations Fair Disclosure. My study extends this research by investigating the disclosure of IC quality and information asymmetry in the secondary loan market. 


\section{CHAPTER 3}

\section{LITERATURE REVIEW}

\subsection{Disclosure of ICFR}

One of the difficulties of researching IC is its broad definition due to the complexities of the internal control process (Kinney, 2000). This makes operationalizing the quality of internal controls as a research construct difficult. Moreover, internal controls are processes that are dissimilar across firms, industries, regulatory regimes, cultures, and time. Additionally, the auditing process in terms of time, effort, and expertise affects the quality of internal control. The "tone at the top" or the management's philosophy towards internal controls might also exacerbate incidents of poor financial quality over internal control (Ogneva, Subramanyam, and Raghunandan, 2007). All of these dynamic factors mediate internal control quality and thus limit the generalizability of research in this area.

The quality of internal control systems has been operationalized in prior research using many proxies such as: internal audit quality, quality assurance and oversight (Haron, Ibrahim, Jeyaraman, and Chye, 2010), owners' investments in internal control (Pae and Yoo, 2001), and disclosure of material weaknesses versus effective internal control (Feng, Li and McVay, 2009; Doyle, Ge, and McVay, 2007a,b; Ashbaugh-Skaife, Collins, Kinney, and LaFond, 2008). Owner's investment in internal controls is part of the agency costs incurred to align the interests of management and shareholders. Failure to maintain an effective internal control system is thus an expropriating of the shareholder's wealth in a firm.

A material weakness in ICFR is defined by the PCAOB (2004) as: "one or more deficiencies that results in more than a remote likelihood that a material misstatement of the annual or interim financial statements will not be prevented or detected.” Material restatements 
occur when: (1) an inherent risk leads to the occurrence of material errors/misstatements, GAAP violations or internal audit failure; (2) no one was able to prevent or detect these material restatements before the release of audited financial statements; (3) the audited financial statements are released and the auditor, by default, did not discover the presence of material misstatements; and (4) someone (e.g., internal auditor, external auditor, an employee, top management, Board of Directors) detects material misstatements and hence corrected financial statements must be issued with the discoverable material restatements (Eilifsen and Messier, 2000).

Higher levels of disclosure can either suppress the informed trader's search for private information or motivate uninformed investors to actively engage in trading activities. In either case, the result of disclosure is reduced information asymmetry. The main purpose of the disclosure of material Internal Control Deficiencies is to resolve financial reporting uncertainty about the firm (Beneish, Billings and Hodder, 2008). Hence, such disclosure should reduce asymmetric information in the market because uninformed investors receive additional information that might reduce their level of motivation to search for private information. However, Beneish et al. (2008) argue that internal control disclosures might increase information asymmetry (uncertainty) because the disclosure of Internal Control Deficiencies signals increased risk to the market. Beneish et al. (2008) find that SOX 302 might have a negative impact on stock returns especially with the presence of IC material weaknesses. They also examined the market reaction to SOX 404 and did not document an association between the disclosure of ICMW and stock returns.

There are three types of IC weaknesses including: control deficiencies, significant deficiencies, and material weaknesses (Hammersley, Myers, and Shakespeare, 2008; Bryan and 
Lilien, 2005). Significant deficiencies and material weaknesses are referred to as Internal Control Deficiencies (ICDs) in the prior literature (Leone, 2007). Prior research focuses mainly on material weakness, because it has the most severe consequences on the firm and must be disclosed under SOX 2002 provisions. Hammersley, Myers, and Shakespeare (2008) find that the market reacts to the disclosure of significant deficiencies and material weaknesses, but they did not detect a similar reaction to the disclosure of control deficiencies. Stated differently, firms with disclosed material weaknesses are characterized as high-risk, in which investors, mostly uninformed investors, ask for a higher risk premium to offset the perceived increased risk of such firms. Material weaknesses are also a signal to the market that the disclosing firm has poor financial reporting quality. Poor financial reporting quality can thus exacerbate information asymmetry (Ogneva, Subramanyam, and Raghunandan, 2007). However, some Internal Control Deficiencies might not reduce uncertainty, but rather infuse uncertainty in the market and hence increase information asymmetry (Beneish, Billings and Hodder, 2008; Kim and Park, 2009).

A key element of the literature on disclosure of ICFR is that it contains two types of disclosure: mandatory disclosure under section 404 and voluntary disclosure under section 302. Researchers try to avoid providing biased estimates based on introducing variables related to voluntary (e.g., control deficiencies, significant deficiencies) versus mandatory (e.g., material weakness) disclosure. Lam and Du (2004) hypothesize that mandatory disclosure is expected to be associated with low cross-sectional estimation risk. They find a significant negative relationship between voluntary disclosure that is certified by the audit firm and risk-adjusted returns in the secondary equity market. However, they find no such association between the quantity of private information and risk-adjusted returns. They also find no association between the information environment and the risk-adjusted return in the primary market. 
Research on SOX 2002 - IC related provisions extends from pre-SOX 2002 to post-SOX 2002 - section 404 periods (Beneish, Billings and Hodder, 2008). Tables 1-7 summarize a sample of studies on this line of research. In summary, I classify this research into three main categories: determinants, characteristics, and consequences of SOX 2002 - IC related provisions. 
TABLE 1

Research on the Association between Disclosure of IC Quality and Cost of Capital pre SOX 2002

\begin{tabular}{|c|c|c|c|c|}
\hline Study & Sample Period & Dependent Variable & Independent Variable (s) & Findings \\
\hline Botosan (1997) & 1990 & Cost of equity capital & $\begin{array}{l}\text { Self-constructed measure of } \\
\text { voluntary disclosure level }\end{array}$ & $\begin{array}{l}\text { (1) For firms with low analysts following, a negative } \\
\text { association between disclosure level and cost of } \\
\text { capital is documented. } \\
\text { (2) For firms with high analysts following, no such } \\
\text { association is reported. }\end{array}$ \\
\hline $\begin{array}{l}\text { Francis, LaFond, } \\
\text { Olsson, } \quad \text { and } \\
\text { Schipper (2004) }\end{array}$ & $1975-2001$ & Cost of equity & $\begin{array}{l}\text { Earnings attribute: (1) } \\
\text { accounting-based attributes } \\
\text { such as: accrual quality, } \\
\text { persistence, predictability, and } \\
\text { smoothness. (2) market-based } \\
\text { attribute such as: value } \\
\text { relevance, timeliness, and } \\
\text { conservatism. }\end{array}$ & $\begin{array}{l}\text { High earnings attributes, individually, are associated with } \\
\text { low cost of equity. }\end{array}$ \\
\hline $\begin{array}{l}\text { Francis, LaFond, } \\
\text { Olsson, and } \\
\text { Schipper (2005) }\end{array}$ & $1988-1999$ & $\begin{array}{l}\text { Cost of capital and } \\
\text { cost of debt }\end{array}$ & Earnings quality measures & $\begin{array}{l}\text { Firms with good earnings quality enjoys lower cost of } \\
\text { capital and cost of debt relative to firms with poor earnings } \\
\text { quality }\end{array}$ \\
\hline
\end{tabular}


TABLE 2

Research on the Disclosure of IC Quality post SOX 2002 - Section 302

\begin{tabular}{|c|c|c|c|c|}
\hline Study & $\begin{array}{l}\text { Sample } \\
\text { Period }\end{array}$ & Dependent Variable & Independent Variable (s) & Findings \\
\hline $\begin{array}{l}\text { De Franco, Guan, and } \\
\text { Lu (2005) }\end{array}$ & $\begin{array}{ll}\text { November } & 1, \\
2003 & \text { to } \\
\text { December } & \\
31,2004 & \end{array}$ & $\begin{array}{l}\text { Wealth change and } \\
\text { redistribution effects of section } \\
404\end{array}$ & $\begin{array}{l}\text { Internal control material } \\
\text { weaknesses }\end{array}$ & $\begin{array}{l}\text { Disclosure of ICMW is associated with negative } \\
\text { significant abnormal returns. }\end{array}$ \\
\hline $\begin{array}{l}\text { Ge and McVay } \\
(2005)\end{array}$ & $\begin{array}{l}\text { August } 2002 \\
\text { to November } \\
2004\end{array}$ & $\begin{array}{l}\begin{array}{l}\text { Disclosure of } \\
\text { weaknesses }\end{array} \\
\end{array}$ & $\begin{array}{l}\text { Resources invested in internal } \\
\text { control system by management }\end{array}$ & $\begin{array}{l}\text { Firms that disclosed material weakness have poor } \\
\text { internal control as characterized by poor revenue } \\
\text { recognition policies, poor segregation of duties, } \\
\text { errors in the end of period process and } \\
\text { deficiencies in polices related to it, and errors in } \\
\text { accounting reconciliation. }\end{array}$ \\
\hline $\begin{array}{l}\text { Gupta and Nayar } \\
(2006)\end{array}$ & $\begin{array}{l}\text { November } \\
2003 \text { - July } \\
2004\end{array}$ & Stock price & $\begin{array}{l}\text { Voluntary disclosure of } \text { IC } \\
\text { weaknesses }\end{array}$ & $\begin{array}{l}\text { (1) IC weaknesses are associated with negative } \\
\text { stock price reaction. } \\
\text { (2) This negative reaction is lessened when the } \\
\text { management discloses remediation actions } \\
\text { taken to mitigate IC weaknesses. } \\
\text { (3) The stock price reaction to IC weaknesses is } \\
\text { less negative also for firms that are audited by } \\
\text { Bid-4 auditing firms. } \\
\text { (4) Moreover, the disclosure of IC weaknesses } \\
\text { affect the short-term default risk because the } \\
\text { stock price negative reaction to the disclosure } \\
\text { of IC weaknesses is more negative for firms } \\
\text { with higher current liabilities relative to total } \\
\text { assets. }\end{array}$ \\
\hline
\end{tabular}


TABLE 2 (Concluded)

Research on the Disclosure of IC Quality post SOX 2002 - Section 302

\begin{tabular}{|c|c|c|c|c|}
\hline Study & $\begin{array}{l}\text { Sample } \\
\text { Period }\end{array}$ & Dependent Variable & Independent Variable (s) & Findings \\
\hline $\begin{array}{l}\text { Doyle, } \quad \text { Ge and } \\
\text { McVay, } 2007 \mathrm{a}\end{array}$ & $\begin{array}{l}\text { August } 2002 \\
\text { to } 2005\end{array}$ & $\begin{array}{l}\text { Firm size, financial condition, } \\
\text { complexity, growth, and } \\
\text { restructuring }\end{array}$ & $\begin{array}{lll}\text { Internal } & \text { control } & \text { material } \\
\text { weakness } & & \end{array}$ & $\begin{array}{l}\text { Firms with internal control material weaknesses } \\
\text { tend to be smaller, financially poor, more } \\
\text { complex, younger, growing fast, and undergoing } \\
\text { restructuring. }\end{array}$ \\
\hline $\begin{array}{l}\text { Doyle, } \quad \text { Ge } \\
\text { McVay }(2007 b)^{16}\end{array}$ & $\begin{array}{l}\text { August } 2002 \\
\text { to November } \\
2005\end{array}$ & Accrual quality & $\begin{array}{l}\text { Internal control } r \text { material } \\
\text { weakness disclosure } \\
\text { level versus account } \\
\text { weaknesses) }\end{array}$ & $\begin{array}{l}\text { (1) Firms with Internal Control Deficiencies are } \\
\text { associated with low quality of accruals. } \\
\text { (2) The above association exists for firms with } \\
\text { company-level Internal Control Deficiencies } \\
\text { and does not exist for firms with account- } \\
\text { specific weaknesses. }\end{array}$ \\
\hline $\begin{array}{l}\text { Ashbaugh-Skaife, } \\
\text { Collins, and Kinney } \\
\text { (2007) }\end{array}$ & $\begin{array}{lr}\text { November } \\
2003 \text { to } \\
\text { December } 31, \\
2004\end{array}$ & $\begin{array}{l}\text { Economic factors for the } \\
\text { presence of internal control } \\
\text { deficiencies and management } \\
\text { incentives to report these } \\
\text { deficiencies. }\end{array}$ & $\begin{array}{lll}\text { Internal control deficiencies } \\
\text { (ICDs) }\end{array}$ & $\begin{array}{l}\text { Firms that disclosed ICDs have more complex } \\
\text { operations, experiencing major restructuring; } \\
\text { have greater risk, have more auditor resignation } \\
\text { and fewer resources invested in internal control } \\
\text { systems. }\end{array}$ \\
\hline $\begin{array}{l}\text { Ashbaugh-Skaife, } \\
\text { Collins, Kinney, and } \\
\text { LaFond (2008) }\end{array}$ & 2003 to 2005 & Accrual quality & ICDs and their remediation & $\begin{array}{l}\text { (1) Firms with ICDs have low accruals quality } \\
\text { and large positive and negative abnormal } \\
\text { accruals. } \\
\text { (2) Firms that remediated their internal control } \\
\text { experienced an increase in their accrual } \\
\text { quality }\end{array}$ \\
\hline
\end{tabular}

\footnotetext{
${ }^{16}$ Doyle, Ge and McVay (2007b) also investigate the association between the accruals quality and ICMWs under section 404.
} 
TABLE 2 (Concluded)

Research on the Disclosure of IC Quality post SOX 2002 - Section 302

\begin{tabular}{|c|c|c|c|c|}
\hline Study & $\begin{array}{l}\text { Sample } \\
\text { Period }\end{array}$ & Dependent Variable & Independent Variable (s) & Findings \\
\hline $\begin{array}{l}\text { Hammersley, Myers, } \\
\text { and } \quad \text { Shakespeare } \\
(2008)\end{array}$ & $\begin{array}{l}3 \text { days } \\
\text { windows } \\
\text { around the } \\
\text { disclosure on } \\
\text { Internal } \\
\text { Control } \\
\text { Deficiencies } \\
\text { under section } \\
302\end{array}$ & Stock pries & $\begin{array}{l}\text { Disclosure of Internal Control } \\
\text { Deficiencies under section } 302\end{array}$ & $\begin{array}{l}\text { (1) The information content of the disclosure of } \\
\text { Internal Control Deficiencies depends on the } \\
\text { severity of the Internal Control Deficiencies. } \\
\text { (2) Overall, they document negative stock price } \\
\text { reaction to the disclosure of IC weaknesses } \\
\text { and material weaknesses }\end{array}$ \\
\hline $\begin{array}{l}\text { Ashbaugh-Skaife, } \\
\text { Collins, Kinney, and } \\
\text { LaFond (2009) }\end{array}$ & $\begin{array}{l}\text { November } \\
2003 \text { to } \\
\text { September } \\
2005\end{array}$ & Firm risk and cost of capital & ICDs & $\begin{array}{l}\text { Firms with ICDs have significantly higher } \\
\text { idiosyncratic risk, systematic risk and cost of } \\
\text { equity. }\end{array}$ \\
\hline Kim and Park (2009) & 2004 & Abnormal stock returns & $\begin{array}{l}\text { Market uncertainty associated } \\
\text { with the disclosure of internal } \\
\text { control deficiencies under } \\
\text { section } 302\end{array}$ & $\begin{array}{l}\text { Abnormal stock returns are negatively associated } \\
\text { with market uncertainty when the firm discloses } \\
\text { internal control deficiencies. }\end{array}$ \\
\hline
\end{tabular}


TABLE 3

Research on the Disclosure of IC Quality post SOX 2002 - Section 404

\begin{tabular}{|l|l|l|l|l||}
\hline \multicolumn{1}{|c|}{ Study } & Sample Period & Dependent Variable & Independent Variable (s) & Findings \\
\hline $\begin{array}{l}\text { Bryan and Lilien ( } \\
\text { 2005) }\end{array}$ & $\begin{array}{l}\text { Two days before } \\
\text { and one day after } \\
\text { the } \\
\text { announcement } \\
\text { date of ICMWs. }\end{array}$ & $\begin{array}{l}\text { Stock returns, firm size, } \\
\text { financial performance, } \\
\text { and firm beta }\end{array}$ & $\begin{array}{l}\text { Internal Control Material } \\
\text { Weaknesses (ICMWs) reported } \\
\text { under section 404 }\end{array}$ & $\begin{array}{l}\text { (1) Firms with ICMWs are financially weaker, } \\
\text { smaller and have higher market betas than those for } \\
\text { firms without ICMWs. } \\
\text { (2) They further document a negative stock price } \\
\text { reaction on the date of the announcement of } \\
\text { ICMWs. }\end{array}$ \\
\hline $\begin{array}{l}\text { Ettredge, Li and } \\
\text { Sun (2006) }\end{array}$ & $\begin{array}{l}\text { January 2005 - } \\
\text { June 2005 }\end{array}$ & Audit delay & $\begin{array}{l}\text { ICMWs are associated with audit delay. } \\
\text { General-ICMWs are associated with longer delays } \\
\text { than that in account specific-ICMWs. }\end{array}$ \\
\hline
\end{tabular}


TABLE 4

Research on the Disclosure of IC Quality on both Section 302 and Section 404

\begin{tabular}{|c|c|c|c|c|}
\hline Study & $\begin{array}{l}\text { Sample } \\
\text { Period }\end{array}$ & Dependent Variable & Independent Variable (s) & Findings \\
\hline Bedard (2006) & $\begin{array}{l}\text { September } \\
2002 \text { to } \\
\text { November } 15, \\
2004\end{array}$ & $\begin{array}{l}\text { Earnings } \\
\text { quality as } \\
\text { measured by accounting } \\
\text { accruals }\end{array}$ & $\begin{array}{l}\text { IC weaknesses under both } \\
\text { section } 302 \text { and section } 404\end{array}$ & $\begin{array}{l}\text { The year of IC weaknesses disclosure synchronizes } \\
\text { with higher earnings quality, implying that either } \\
\text { management or auditors requests increasing the } \\
\text { quality of accounting information prior to the } \\
\text { disclosure of IC weaknesses. }\end{array}$ \\
\hline $\begin{array}{l}\text { Doyle, } \quad \text { Ge and } \\
\text { McVay (2007a) }\end{array}$ & $\begin{array}{l}\text { August } 2002 \\
\text { to } 2005\end{array}$ & $\begin{array}{l}\text { Firm size, } \begin{array}{r}\text { financial } \\
\text { complexity, } \\
\text { condition, } \\
\text { growth, and restructuring }\end{array} \\
\end{array}$ & $\begin{array}{lll}\text { Internal } & \text { control } & \text { material } \\
\text { weakness } & & \end{array}$ & $\begin{array}{l}\text { Firms with internal control material weaknesses tend } \\
\text { to be smaller, financially poor, more complex, } \\
\text { younger, growing fast, and undergoing restructuring. }\end{array}$ \\
\hline $\begin{array}{l}\text { Beneish, Billings } \\
\text { and Hodder (2008) }\end{array}$ & $\begin{array}{l}30,45,90 \text {, and } \\
180 \text { days } \\
\text { before and } \\
\text { after the } \\
\text { disclosure of } \\
\text { ICMW under } \\
\text { both sections } \\
302 \text { and } 404\end{array}$ & Stock returns & $\begin{array}{l}\text { ICMW under both sections } 302 \\
\text { and } 404\end{array}$ & $\begin{array}{l}\text { Disclosure of ICMW under section } 302 \text { is associated } \\
\text { with negative abnormal stock returns, but such } \\
\text { association does not exist under section } 404 \text {. }\end{array}$ \\
\hline
\end{tabular}


TABLE 5

Research on the Disclosure of IC Quality Post Section 404

\begin{tabular}{|l|l|l|l|l|}
\hline \multicolumn{1}{|c|}{ Study } & Sample Period & Dependent Variable & Independent Variable (s) & Findings \\
\hline $\begin{array}{l}\text { Ogneva, } \\
\text { Subramanyam, and } \\
\text { Raghunandan } \\
\text { (2007) }\end{array}$ & $\begin{array}{l}\text { June 2004 and } \\
\text { June 2006 }\end{array}$ & Cost of equity & ICMWs under section 404 & $\begin{array}{l}\text { (1) Firms with ICMWs are associated with } \\
\text { higher implied cost of equity. } \\
\text { This higher cost of equity is mitigated } \\
\text { when they control for analyst forecast } \\
\text { bias and firm-specific characteristics }\end{array}$ \\
\hline
\end{tabular}




\subsubsection{Determinants of ICFR}

In their influential work, Ashbaugh-Skaife, Collins, and Kinney (2007) study the determinants of ICDs prior to SOX 404 and develop expectations of internal control problems. They introduce a theoretical model of the economic factors that contribute to ICD (a control deficiency, a significant deficiency, and a material weakness) as internal control risk factors and management's incentives to disclose and report ICDs, prior to SOX 404 and after section 302. This internal control risk is operationalized in the model by the following factors: the complexity and scope of the firm's operations, change in the firm's organizational structure, accounting measurement application risk, lack of firm resources devoted to internal control, and whether the auditor resigned in 2003. Factors that affect management's incentives to report and disclose ICD include: auditor dominance, prior accounting restatement, the dominance of institutional investors, and litigation risk.

In related research, Doyle, Ge and McVay (2007a) examine one dimension of internal control, material weakness, in the pre-SOX 302 and post-SOX 404 periods. They use a sample of accelerated filers and examine whether the severity of material weaknesses vary based on the reason for the weakness. There are two types of the severity of material weakness, accountspecific material weaknesses (less severe in terms of affecting the reliability of financial statements) and, company-level material weaknesses (more severe). The determinants of IC weakness are classified in Doyle, Ge and McVay (2007a) as a result of staffing, complexity, or general factors.

Leone (2007) refutes claims by Ashbaugh-Skaife, Collins, and Kinney (2007) that suggests evidence on the positive association between big-4 audit firm and management incentives to disclose ICD. They argue that Ashbaugh-Skaife, Collins, and Kinney (2007) results 
are driven by small firms. The fact that smaller firms are more likely to report material weaknesses under section 404 suggests that compliance with section 404 requires additional resources and investment in internal control structure in order to make it an effective system. Ge and McVay (2005) find that disclosing material weaknesses is negatively associated with firm size (market capitalization). Furthermore, Ge and McVay (2005) suggest that insufficient resources in internal controls lead to deficiencies in those internal controls related to revenue recognition, segregation of duties, the closing process, and accounting reconciliation.

\subsubsection{Characteristics of ICFR}

Following the enactment of SOX 2002 - IC related provisions, a stream of research $(\mathrm{Ge}$ and McVay, 2005; Bryan and Lilien, 2005; Ettredge, Li and Sun, 2006; Bedard, 2006; Feng, Li and McVay, 2009) emerges that characterize firms with effective versus ineffective IC systems. Ge and McVay (2005) maintain that firms disclosing material weaknesses under section 302 find material weakness are positively associated with business complexity (e.g., number of reported operating segments and foreign currency translation) and being audited by large firms and negatively associated with firm size and profitability. Similarly, Bryan and Lilien (2005) characterize firms with internal control material weaknesses under section 404, finding that firms with disclosed material weaknesses are generally small, poorer performers, financially weaker, and with higher market risk. They also find that the market reacts negatively to the announcement of material weaknesses, but the documented negative stock returns are statistically insignificant. Similarly, Bedard (2006) further explains the improvements in earnings quality reported under section 404 as a result of the formal internal control process performed under this section, either by the internal control system or the external auditor. 
Ettredge, Li and Sun (2006) find that the compliance with section 404 is associated with auditor delay. It is worthwhile to note that the audit delay documented in Ettredge, $\mathrm{Li}$ and Sun (2006) is attributed to section 404 and not SOX 2002 itself. The audit delays associated with section 404 can be explained by the insufficiency of internal control procedures in firms with ICMWs and the inadequacy and/or ambiguity associated with extended internal control auditing (inquiries, observations, inspections, and evaluation of internal control) as was initially required under AS2 and then amended by AS5 by the PCAOB.

Bedard (2006) investigates whether the requirements of sections 302 and 404 have increased the quality of earnings. She finds that management, whether voluntarily or based on a request from the external auditor, reversed the accrual they made in prior years to the disclosure of internal control material weaknesses. However, the magnitude of earnings manipulations reported under section 302 was more than that reported under SOX 404, implying that there are significant differences in the consequences of implementing section 302 versus section 404 .

Feng, Li and McVay (2009) test the relationship between internal control quality and accuracy of management guidance. They find that relying on an ineffective internal control system results in less accurate management guidance. Accurate management guidance decreases information asymmetry through enhancing the transparency and credibility of their financial reporting. Moreover, the negative impact of ineffective internal control is higher when the weaknesses in internal control are related to revenues and cost of goods sold. Overall, they argue that the quality of internal control has a significant effect on management decisions.

\subsubsection{Consequences of ICFR}

Research on the consequences of the disclosure of IC weaknesses was triggered by the seminal work of Ashbaugh-Skaife, Collins, and Kinney (2007) and Doyle, Ge and McVay 
(2007a), which set the determinants for disclosing ICDs. However, the consequences of IC weaknesses on the firm are not clear. Research on the consequences of IC weaknesses has shown mixed results. For example, Ashbaugh-Skaife, Collins, and Kinney (2009) find a positive association between the cost of capital and disclosure of material weaknesses under sections 302 and section 404. Ogneva, Subramanyam, and Raghunandan (2007) do not find the same relation under section 404. Beneish, Billings and Hodder (2008) analyze whether the disclosure of material Internal Control Deficiencies under SOX 302 and SOX 404 is related to investor belief revision. ${ }^{17}$ They find that the unaudited disclosure of ICMWs under SOX 302 causes an abnormal increase in the equity cost of capital and negative abnormal returns.

In the same domain, De Franco, Guan, and Lu (2005) discuss the wealth change and redistribution effects of SOX internal control disclosure. They argue that the benefits of SOX 404 are obscure or non-existent. They observed a significant change of wealth in the three days surrounding the disclosure of internal control deficiencies, suggesting that the disclosure of an internal control deficiency is new information in the market and investors incorporate this news in their investment decision. They find cumulative average abnormal returns of $-1.8 \%$ during the three days surrounding the disclosure of internal control deficiencies. They also argue that the net selling of small investors explain these negative returns. This result implies that SOX 404 causes redistribution of wealth from large (sophisticated) to small investors because large investors react indifferently to the disclosure of significant deficiencies while small investors sell their stock in response to the disclosure of those deficiencies. In other words, small investors benefit more from material Internal Control Deficiencies or significant deficiencies disclosures. Overall, their findings support the conjecture that investors factor the disclosure of internal

\footnotetext{
${ }^{17}$ Belief revision can be defined as the act of continuously changing beliefs due to the arrival of new information to the market.
} 
control deficiencies (a piece of information that is assumed to be unknown by investors until it is disclosed) into their decision making.

Irving (2006) finds that the disclosure of material weakness has information content as measured by stock return volatility and trading volume. Moreover, he provides empirical evidence on the incremental information content of section 404 over section 302. Likewise, Haron, Ibrahim, Jeyaraman, and Chye (2010) investigate the relationship between IC disclosure and firm performance. They used proxies to measure IC disclosure such as: internal audit quality, quality assurance and oversight. Firm performance is measured by return on asset (ROA) and return on equity (ROE). Overall, their findings suggest that well-performing companies voluntarily disclose internal control effectiveness in their financial reports.

\subsection{Information Asymmetry in the Secondary Loan Market}

Information asymmetry in the secondary loan market can be visualized as the ex ante quality and quantity of differential information between borrowers and lenders or among lenders themselves. Similarly, Verrecchia (2001) defines information asymmetry as "the difference in the cost of capital in the presence versus absence of an adverse selection problem that arises from information asymmetry (p. 171)." Hence, decomposing information asymmetry into its components is important to effectively measure the impact of poor quality financial reporting on information asymmetry.

Information asymmetry that is affected by certain loan characteristics is presumably a long-term phenomenon because loan characteristics are set at the beginning of the loan contract and arrangements are usually made over a longer time period. Information asymmetry is also affected by private information held by insiders. An apparent example of this private information is research and development costs (R\&D). Some sectors in the economy are considered R\&D- 
intensive firms such as high growth firms, investment firms, and intangible-intensive industries. Aboody and Lev (2000) find that information asymmetry is higher for R\&D-intensive firms and lower for firms with lower or no $R \& D$ activities. They argue that $R \& D$ is an inside (private) source of information leading to information asymmetry and insider gains.

Disclosure quality affects the ex ante distribution of the firm's cash flow; this effect depends on investors' perceptions of the disclosure signal. Gao (2010) argues that disclosure quality could increase the cost of capital under two conditions. First, if the disclosure increases the variance of the firm's cash flow as a proxy for investment effect. Second, if the investment effect is growing more than the increase in the stock price due to the disclosure quality. Taken together, as disclosure quality increases, the cost of capital does not necessarily decrease.

I use the bid-ask spread as a proxy for information asymmetry. The bid-ask spread has been used extensively in prior studies that examine information asymmetry in the secondary loan market. Moerman (2008) suggests that the use of the bid-ask spread might be problematic because it includes an adverse selection component and a transitory component. The adverse selection component is the asymmetric information, and the transitory component is the inventory and order processing costs of market makers that can be measured by the number of market makers and could be endogenously associated with the IA. Information asymmetry is the adverse selection component in the bid-ask spread.

The bid-ask spread consists of three components: order processing, inventory, and adverse selection (Bharath, Pasquariello, and $\mathrm{Wu}, 2008$ ). The adverse selection component can be extracted from either the serial covariance properties of the time series of observed asset returns, the interaction between trading volume and asset returns, or the arrival of informationbased trades from the estimates of structural equation modeling. 
Various measures in the market microstructure literature have been used to capture the adverse selection components caused by information asymmetry such as: analyst coverage, dispersion of analysts' forecasts, magnitude of earnings surprises, residual stock return volatility, or trading volume. Among these measures are the bid-ask spreads, transaction costs, trades, quotes, or even an index such as that in Bharath, Pasquariello, and Wu (2008).

Bharath, Pasquariello, and $\mathrm{Wu}$ (2008) use an innovative measure to capture the adverse selection components in information asymmetry between management and shareholders. They create an index for information asymmetry composed of four measures of information asymmetry: 1. the adverse selection component of both quoted, 2. effective bid-ask spreads, 3 . the probability of informed trading, and 4. the interaction between daily trading volume and asset returns. They also incorporate three measures of market liquidity (the liquidity ratio, the illiquidity ratio, and the reversal coefficient) in their analysis.

As a robustness check, Frankel and Li (2004) document a negative association between analyst following and bid-ask spread. Overall, the results using the bid-ask spread as a proxy for information asymmetry are consistent with those using profitability and intensity of insider trading as proxies for information asymmetry (Frankel and Li, 2004).

Information asymmetry, as measured by high bid-ask spreads, exists between borrowers and lenders or among lenders themselves (Ball, Bushman, and Vasvari 2008). This information asymmetry can affect the loan value, interest rate, maturity, covenants or other aspects of formal contractual features. Moreover, high spreads are an indication of market imperfection (Angbazo, Mei and Saunders, 1998). Ball, Bushman, and Vasvari (2008) argue that the proportion of the loan that is held by the lead arranger is dependent on the increasing adverse selection and moral hazard problems created by information asymmetry. Bharath, Pasquariello, and Wu (2008) argue 
that information asymmetry is a key determinant of corporate capital structure. They provide support to the pecking order theory, which contends that the market penalizes the issuance of securities when managers retain more private information (well informed traders) than that retained by investors (less informed traders). Therefore, when adverse selection is high (high information asymmetry exists), firms are more likely to use other sources of financing such as internal cash, or public or private debt. 


\section{CHAPTER 4}

\section{HYPOTHESIS DEVELOPMENT}

\subsection{Disclosure of IC Quality and Information Asymmetry}

Verrecchia (2001) suggests that information asymmetry is a decreasing function of a comprehensive theory of disclosure. He describes the reduction in information asymmetry as "the vehicle to integrate the efficiency of disclosure choice, the incentives to disclose and the endogeneity of the capital market process as it involves the interactions among individual and diverse investors (p. 97-98)." Verrecchia (2001) argues that there are two schools of thought that attempt to explain the association between disclosure and information asymmetry; a positive school suggesting a positive association and a negative school suggesting a negative association between disclosure and information asymmetry. The positive perspective argues that the firm might reach a position in which it uses a combination of the liquidity premia and less than full disclosure to offset the proprietary costs resulting from a reduction of information asymmetry. In this case, the firm discloses more information to the extent that it mitigates the adverse selection problem reducing information asymmetry. In the second perspective, a negative association between disclosure and information asymmetry suggests that full disclosure resolves the asymmetric information in the market.

Of particular relevance to my study are studies that: (1) examine the association between disclosure, both mandatory and voluntary, and information asymmetry, and (2) investigate the relationship between disclosure quality and cost of capital as a proxy for information asymmetry. Studies that examine the association between mandatory and voluntary disclosures and information asymmetry include Brown and Hillegiest (2007) and Ogneva, Subramanyam, and Raghunandan (2007). Brown and Hillegiest (2007) argue that disclosure quality reduces the 
likelihood that investors will trade based on private information, hence reducing the information asymmetry between informed and uninformed investors. In other words, quality disclosures obviate the incentives of informed traders to search for private information. They further investigate whether three areas of disclosure quality are associated with information asymmetry. The three types of disclosure quality examined are: the annual report, the quarterly reports, and investor relations activities. Their findings suggest that the quality of disclosure associated with the annual reports and investor relations activities are negatively associated with information asymmetry. However, the disclosure quality of the quarterly reports is positively associated with information asymmetry. They explain that the negative association between annual disclosure and information asymmetry in annual reports is high in credibility, is audited, is precise and more detailed, and is subject to litigation.

The disclosure of investor relations is voluntary and is more timely compared to annual reports. However, the negative relationship between quarterly reports and information asymmetry suggests that quarterly reports are less credible. Additionally, Brown and Hillegiest (2007) find that information asymmetry varies across firms and industry-years.

In testing the construct validity of their study, Ogneva, Subramanyam, and Raghunandan (2007) examine the association between Internal Control Deficiencies and information asymmetry (as a proxy for the cost of capital) in the equity market. They use the probability of informed trading (PIN) and market risk measures as a proxy for information asymmetry. Overall, they find no direct relationship between Internal Control Deficiencies and information asymmetry after controlling for firm-specific characteristics.

Ogneva, Subramanyam, and Raghunandan (2007) conclude that firms with Internal Control Deficiencies post-SOX 404 and prior to AS5 have higher costs of equity capital. 
Nevertheless, the positive effect between the reporting of material weakness and cost of equity capital dissipates after controlling for firm specific-characteristics and analysts' forecasts bias, implying an indirect association between the disclosure of material weaknesses and cost of equity capital.

Bushee, Core, Guay, and Hamm (2010) find that the business press is an information intermediary that results in greater depth of coverage hence reducing information asymmetry as measured by the bid-ask spread around earnings announcements. They argue that the business press provides a broader impact and depth than that provided by the non-business press generated information.

Studies that investigate the relationship between disclosure quality and cost of capital are numerous and extend from pre-SOX 2002 (Botosan, 1997; Francis, LaFond, Olsson, and Schipper, 2004 and 2005) to post-section 404 (Ogneva, Subramanyam, and Raghunandan, 2007). The primary purpose of this stream of research is to serve as an intermediate step towards understanding the ex ante impact of disclosure quality on investor's welfare and hence the economy (Gao, 2010).

Theoretically, a reduction in the cost of capital might be a signal on the positive impact of disclosure quality on investor welfare. However, anecdotal evidence suggests that the disclosure environment exists in complex settings. Among the complex variables, which interact with disclosure are investor risk-taking characteristics (e.g., risk-averse current investors are more likely to get the benefit of quality disclosure) and adjustment cost of new investment (Gao, 2010). Under these complex settings, a reduction in the cost of capital may not represent an increase in wealth for both current and prospective investors. According to Gao(2010), the cost of capital captures the impact of disclosure quality on investor welfare only under certain 
circumstances such as: the availability of elastic new investments, conditions that reduce the welfare of current and new investors, and the directional relationship between cost of capital and welfare of current and new investors. For example, high disclosure quality decreases current investors' welfare if they are risk-averse relative to new investors while the cost of new investment is high. Gao (2010) argues that "disclosure quality makes new investors better off only in a production economy. New investors gain a surplus from trading by contributing their risk tolerance to the market (P. 3)." Gao (2010) concludes that disclosure reduces new investors' wealth, if and only if, the level of existing investment and the adjustment cost of new investment are both high.

Beneish, Billings and Hodder (2008) analyze whether the disclosure of audited (SOX 302) and unaudited (under SOX 404) internal control material weakness is related to investor belief revision. They find that the unaudited disclosure of material weakness causes an abnormal increase in the equity cost of capital and negative abnormal returns. However, audited disclosure of material weakness has no impact on either stock returns or cost of equity. Hence, they conclude that the disclosure of material Internal Control Deficiencies under SOX 302 is informative because it reduces pre-disclosure uncertainty for firms, while SOX 404 audited disclosure does not. In the same vein, Kim and Park (2009) examine the stock market reactions to the disclosure of material weaknesses under section 302. They find that abnormal stock returns are negatively associated with changes in market uncertainty when the firm discloses internal control deficiencies. They further find that the impact of internal control disclosure on market uncertainty is conditional on many factors including, the types of disclosure and the firm's past history of providing credible financial reporting. Overall, when the disclosure of Internal Control Deficiencies reduces the uncertainty in the market, the negative impact on the 
contemporaneous stock returns of the disclosing firm is lessened. They also find voluntary disclosure of non-material weaknesses under section 302 reduces market uncertainty.

Gupta and Nayar (2006) suggest that disclosure of material weaknesses may lead banks and short-term lenders to devalue the collateral potential of the borrowing firms' financial assets. Moody's Investor Service (2004) and Fitch Rating (2005) also point out that material weaknesses might trigger debt rating changes which in turn increase the probability of default as well as borrowing costs.

Disclosure of Internal Control Deficiencies should compensate traders for the uncertainty surrounding the reporting quality by causing belief revisions regarding the firm's internal control risk. Therefore, uninformed investors are more likely to benefit from this weakness disclosure and less likely to face an adverse selection problem (Beneish, Billings and Hodder, 2008). Moreover, uninformed traders, small investors or unsophisticated investors are more likely to alter their trading behavior or leave the market (Frankel and Li 2004; De Franco, Guan, and Lu, 2005).

Theoretically, disclosure of IC weaknesses should provide more information and hence reduce information asymmetry to the extent that it alleviates prior uncertainties surrounding the firm. Voluntary disclosure of internal control quality under SOX 302 presumably provides more information than that provided by mandatory disclosure under SOX 404. That is because under section 302, firms disclose ICDs which incorporate both material weaknesses and significant deficiencies. However, under section 404, firms disclose only material weaknesses. Therefore, the quantity of disclosed information under section 302 is more than that disclosed under section 404. 
Additionally, proponents of section 302 might argue that it results in incremental value because it discloses Internal Control Deficiencies (ICDs) which includes both material weaknesses and significant deficiencies. Nevertheless, I argue that disclosing significant deficiencies causes variability in stakeholders' beliefs in two ways. First, stakeholders might perceive a reported significant deficiency as negative, as it might become a material weakness in the future. Second, stakeholders might also perceive a significant deficiency as positive, as it bears low risk and they expect the firm to take remedial action to mitigate the deficiency in the near future. Therefore, in this latter case, ICDs signal to the market a lower prospective risk associated with investment in ICD firms. I base my prediction on prior research reporting that IC disclosure under section 302 increases market uncertainty (Kim and Park 2009; Beneish et al. 2008). ${ }^{18}$ I predict that disclosure of internal control quality under section 302 is incomplete due to the nature of voluntary disclosures associated with it. Incomplete disclosure therefore stimulates investors and creditors to search for private information in an effort to reduce perceived information asymmetry.

Moreover, voluntary disclosure is often perceived as less credible than mandatory, wellregulated disclosure. Another point to consider is endogeneity. ${ }^{19}$ Endogeneity between information asymmetry and the source of information is likely to be more pronounced in the case of voluntary disclosure by firms (Frankel and Li 2004). This latter premise suggests a higher level of uncertainty associated with SOX 302 relative to that associated with section 404 . I also predict that disclosure quality of internal control reported under section 302 differs from that under section 404. Disclosure quality can be measured using many metrics including: quantity of

\footnotetext{
${ }^{18}$ Kim and Park (2009), however, predict that some types of ICDs help reduce market uncertainty.

${ }^{19}$ Endogeneity is a statistical problem caused by omitted variables or measurement error in the Multivariate Analysis Regression Model.
} 
value-relevant information of internal control disclosures, timeliness of disclosures, precision of reported weaknesses, and the credibility of the reports. I conjecture that not all disclosed information is of equal value to stakeholders, even if some disclosures contain more voluntary information than other disclosures. Traders are interested in information that is relatively more persuasive, strategic, verifiable "audited", timely, accurate, and relevant. I also propose that uncertainty in internal control disclosures is a key determinant of internal control disclosure quality $^{20}$. Greater uncertainty is an indication of the presence of private information; hence lower information asymmetry offsets higher uncertainties.

Taken together, I predict that disclosure of Internal Control Deficiencies (low internal control quality) will result in increasing the cost of processing information and create the need for private information to reduce information asymmetry. Likewise, high disclosure quality of Internal Control Deficiencies reduces the need to search for private information as information asymmetry is reduced by the high quality of the disclosure. I base my suppositions on the argument that the firm's commitment to a higher level of IC quality results in reduced information asymmetry in the market. In my first hypothesis, I am focusing on IC quality under SOX 2002, section 302 versus section 404 because of the significant differences between the market responses to section 302 versus those to section $404^{21}$.

\footnotetext{
${ }^{20}$ Uncertainty can be captured by dispersion of analyst forecasts as measured by: $\ln [(\operatorname{standard}$ deviation of forecast earnings per share in the 4th month of the fiscal year/stock price) + 0.001] (Brown and Hillegiest 2007).

${ }^{21}$ I do have the 'deal active date' in the secondary loan market database and I was able to clearly identify firms that reported ICDs under section 302 versus section 404. For example, facilities that are traded after the enactment date of Section 404, on or after November 15, 2004, are classified among the group of firms that belong to post section 302 period (section 404). While this classification may end up with more than one disclosure for a specific firm for the year 2004, some of these disclosures belong to section 302 and the other belongs to section 404, there is no redundancy in the disclosure or overlap. Also, the two sections disclosures are controlled in the model by an indicator variable for section 302 and section 404. Removing observations for firms that reported twice in 2004 under section 302 and section 404 will eliminate a large number of observations from my sample and hinder the statistical analyses.
} 
Therefore, one would expect a high level of disclosure under section 404 to be associated with more reduction in information asymmetry than that documented under section 302 , if any. For example, prior research concludes that ICDs reported under section 302 are associated with negative stock returns (Gupta and Nayar 2006; Beneish, Billings and Hodder 2008) and higher cost of capital (Ashbaugh-Skaife, Collins, Kinney, and LaFond, 2009). Based on the findings of Beneish, Billings and Hodder (2008), there is no information content in the disclosure of section 404. Doyle, Ge and McVay (2007b) show no association between section 404 and low earnings quality as measured by abnormal accruals. Additionally, Ogneva, Subramanyam, and Raghunandan (2007) find that section 404 has no effect on the cost of equity capital. Hence, I hypothesize that section 404 will be associated with lower information asymmetry than that associated with section 302. Based on the preceding argument, I hypothesize the following relationships:

Hla: In the secondary loan market, the disclosure of Internal Control Deficiencies is positively associated with information asymmetry post SOX 2002.

H1b: In the secondary loan market, firms with Internal Control Deficiencies reported under section 302 have significantly higher information asymmetry than firms with Internal Control Deficiencies reported under section 404.

\subsection{Types of IC Weaknesses and Information Asymmetry}

Surprisingly, AS2 does not provide clear guidance on the types of IC weaknesses that should be disclosed. As a result, I use two main classifications of Internal Control Deficiencies from prior literature: (1) material weaknesses, significant deficiencies, and control deficiencies; (2) company-level and account-specific weaknesses.

The first classification of IC weakness was discussed in AS2. Underlying this classification, De Franco, Guan, and Lu (2005) stratify internal control deficiencies into three categories in order of severity: material weaknesses, significant deficiencies, and unspecified or 
control deficiencies. Unspecified or control deficiencies have been defined by AS2 as those deficiencies resulting from a lack of operational control that hinders management or employees from preventing or detecting misstatements in a timely manner. A significant deficiency is one or more combinations of a control deficiency that negatively affects the firm's ability to accurately initiate, record, and process external financial data according to GAAP. A significant deficiency indicates that there is a remote likelihood that a more than inconsequential misstatement of the firm's financial statement will not be either detected or prevented. If there is more than a remote likelihood that a material misstatement will not be prevented or detected, then the significant deficiency is classified as a material weakness. Similarly, Hammersley, Myers, and Shakespeare (2008) find that the market reacts to the disclosure of significant deficiencies and material weaknesses, but they did not detect the same reaction to the disclosure of control deficiencies.

The second classification has been a main topic of discussion by both academicians and practitioners. Underlying this classification, Ettredge, Li and Sun (2006), PCAOB, AS2, and Moody's (2004) categorize internal control systems into company-level and specific-account internal control issues. Company-level internal control issues are those weaknesses in internal control that impact a wide range of general control issues such as: the audit committee, risk assessment, revenue recognition, and the internal audit function. Specific control issues are those that affect a narrow activity inside the internal control system such as account-specific balances (e.g., inventory, accounts payable, accounts receivable). Moody's Investor Services stated in October 2004 that they are less concerned about material weaknesses that relate to specific accounts or transaction-level processes. Moody's Investor Services also stated that they will not consider such weaknesses in their rating evaluations. However, material weaknesses that relate to company-level controls may trigger rating actions by Moody's. 
Another classification of internal control material weaknesses (ICMW), I am not using in my analysis, is based on the Committee of Sponsoring Organization's (COSO) framework. There are eight types of ICMW according to the COSO (1992) classification including personnel, processes and procedures, documentation, segregation of duties, information systems processes, risk assessment/control design, closing processes, and the control environment. Little research has examined the consequences of material weaknesses under the COSO classification due to the lack of supporting theory (Ettredge, Li and Sun 2006.) Feng, Li and McVay (2009) argue that not all material weaknesses result in uncertainties. They further claim that material weaknesses related to segment disclosure, balance sheet classification, or cash flow classification do not negatively affect the input quality for financial reporting. In this study, I use two classifications for IC weaknesses: (1) material weaknesses, significant deficiencies, and control deficiencies, and (2) company-level and account-specific weaknesses. I do not use the COSO classification as it is difficult to define the severity of Internal Control Deficiencies based on that classification. However, AS 2 and company versus account-specific weaknesses consist of validated measures for the severity of internal control deficiencies and can be used as reliable measures in my models.

In summary, prior research suggests that different types of IC weaknesses result in varying degrees of uncertainty. Overall, the more severe the IC weakness, the more likely investors will perceive higher information asymmetry. In this case, the disclosure of these IC weaknesses will be perceived by uninformed traders as requiring them to seek more private information to reduce that asymmetry. Conversely, this will induce informed traders to lessen their trading activities. The overall effect is more information asymmetry between lenders and participant lenders. Based on this conjecture, my second hypothesis is: 
H2a: In the secondary loan market, firms with Internal Control Material Weaknesses have significantly higher information asymmetry than those with Significant and/or Control Deficiencies post SOX 2002.

$H 2 b$ : In the secondary loan market, firms with company-level weaknesses have significantly higher information asymmetry than those with account-specific weaknesses post SOX 2002.

\subsection{Remediation of IC Weaknesses and Information Asymmetry}

To mitigate the problem of omitted correlated variables, I follow Feng et al. (2009) by performing both level (the type of severity of material weaknesses) and change analysis (the change in internal control material weakness). I then test how information asymmetry changes as the quality of internal control changes. The change in ICMWs can be measured as the difference between the indicator variable in year $t-1$ and the indicator variable in year $t$ as suggested by (Feng et al. 2009.) Another method to measure the change in IC weakness is to trace the ICDs reported under section 302 and their subsequent remediation (Ashbaugh-Skaife, Collins, Kinney, and LaFond 2008). IC remediation is measured by section 404 audit opinions, where an unqualified opinion indicates remediation, and an adverse opinion indicates persistence of IC weaknesses and problems. I expect a negative association between the remediation of IC weaknesses and information asymmetry. In other words, firms that take corrective actions to fix internal weaknesses are more likely to reduce uncertainty among uninformed traders and resolve asymmetric information regarding IC weaknesses.

Gupta and Nayar (2006) examine whether the voluntary disclosure of material weakness (post-SOX 2002 and prior to section 404) by SEC registrants convey value-relevant information to the U.S. equity market. They find that the voluntary disclosure of material weakness is associated with a negative stock price reaction and this reaction is mitigated when the disclosing firms also report remediation action to resolve the disclosed material weaknesses. Surprisingly, 
they find that the voluntary disclosure of material weaknesses indeed convey value relevant information.

In a related study, Ashbaugh-Skaife, Collins, Kinney, and Lafond (2008) find that firms that improved internal control, by going from adverse to unqualified SOX 404 opinions, show a significant increase in accrual quality and hence an improvement in the quality of financial statements. I am interested in studying the impact of the remediation of IC weaknesses under section 302 and section 404. Remediation of IC weaknesses under section 302 will be measured by remediating action to eliminate ICD. Under section 404, remediation will be measured by SOX 404 opinions. Based on these arguments, my third hypothesis is:

H3: In the secondary loan market, firms that remediate their Internal Control Deficiencies have significantly lower information asymmetry than firms that did not remediate their Internal Control Deficiencies post SOX 2002.

\subsection{The Moderating Effect of the Secondary Loan Market Characteristics on the Association between Information Asymmetry and ICDs}

I also test the moderating effect of loan specific characteristics on the association between internal control deficiencies and information asymmetry. Among the loan specific characteristics of interest to my study are the number of lenders or syndication, the availability of either firm and/or loan credit rating and the existence of debt covenants. I focus on testing the association between the interaction term of the existence of internal control deficiencies and the three loan specific characteristics and information asymmetry based on the documented evidence in prior research. More specifically, recent studies find that these three loan-specific characteristics have a negative statistical association with information asymmetry (Sufi, 2007; Moerman, 2008; Ball, Bushman, and Vasvari, 2008; Lee and Mullineaux, 2004). 


\section{Syndication}

Syndication is the process of reselling the loan to multiple lenders. The main reason beyond syndication is diversification (Simons, 1993.) However, there are some rules that govern syndication. More specifically, Sufi (2007) finds that the lead arranger retains a larger share of the loan when the borrower needs thorough monitoring and due diligence. Moreover, when information asymmetry between lender and lead arranger is high, the lead arranger and participant lenders try to be as close as possible from the borrower. Stated differently, syndication is more likely to be concentrated when the information available about the borrower is very poor (Lee and Mullineaux, 2004.) The documented evidence in prior literature suggests that higher information asymmetry creates less loan syndication and higher cost of capital.

I expect that the number of lenders is a decreasing function of information asymmetry. Ball, Bushman, and Vasvari (2008) argue that the proportion of the loan that is held by the lead arranger is dependent on the increasing adverse selection and moral hazard problems created by information asymmetry. Therefore, the higher the information asymmetry, the more likely the majority of the loan will be held by the lead arranger and the loan will be less syndicated. Likewise, the lower the information asymmetry, the more likely the lead arranger will sell the loan to multiple arrangers. In summary, I would expect a significant negative association between the interaction term between ICDs and syndication and information asymmetry.

\section{Credit Rating}

Independent credit rating agencies provide credible information about the company performance and thus help reduce the asymmetric information between lead arranger and borrower (Ball, Bushman, and Vasvari, 2008). Credit ratings also signal the default probability. When firms have high default probability, the loan is more concentrated and less syndicated (Lee 
and Mullineaux, 2004.) Ball, Bushman, and Vasvari (2008) document that the availability of credit rating moderates the effect of Debt Contracting Value on the loan retained by lead arranger. In the same vein, Moerman (2008) provides clear evidence that loans with an available credit rating are associated with lower bid-ask spreads. Moerman (2008) argues that "The availability of firm-specific and/or loan-specific credit ratings also decreases information costs in the loan trade, P.242." Additionally, Sufi (2007) argues that when the borrower has no credit rating, participant lenders try to be geographically closer to the borrower. Participant lenders might also make their syndication decision based on previous relationships with the lender. To sum up, I would expect a significant negative association between the interaction term between ICDs and the existence of credit rating and information asymmetry.

\section{Financial Debt Covenants}

While almost all loans have debt covenants in general, not all loans have financial debt covenants. $60 \%$ of the full sample of the secondary loan market data that is available to me (14781 firm-years facilities) from 1987-2005 are loans with no financial debt covenants. Some studies such as Moerman (2008) examined the effect of the existence of various types of debt covenants on the firm's cost of capital, assuming that debt covenants always exist but some studies such as Bradley and Roberts (2004) examine the effect of the existence versus the absence of financial debt covenants on the loan structure. I am following Bradley and Roberts (2004) in incorporating the existence of financial debt covenants into my analyses.

Theoretically, the financial debt covenants should mitigate the asymmetric information between lead arranger and participant lenders because they restrict the earnings manipulation and hence provide reliable and quality financial reporting, which decreases the asymmetric information. However, Bradley and Robert (2004) suggest that bond yield is lower when there 
are debt covenants in the loan contract. They also suggest that high growth firms are more likely to include covenants to restrict their use of funds. Moreover, Dichev and Skinner (2002) provide evidence on the debt covenant hypothesis, which contends that management is more likely to manipulate earnings when they are about to violate debt covenants. In conclusion, there is mixed evidence on the association between the existence of debt covenants and information asymmetry. However, I will expect a significant negative association between the interaction term of debt covenants and internal control deficiencies and information asymmetry. My predication is based on the premise that the interaction term would lessen, but not eliminate, the information asymmetry in the secondary loan market. Based on the preceding argument, I hypothesize the following relationships:

H4: In the secondary loan market, loan-specific characteristics, namely, credit rating, debt covenants, and syndication mitigate the positive association between Internal Control Deficiencies and information asymmetry. 


\section{CHAPTER 5}

\section{RESEARCH METHODOLOGY}

\subsection{Research Model}

I use multivariate analysis regression to examine the association between internal control quality and information asymmetry in the secondary loan market. The dependent variable in my models is information asymmetry as measured by the bid-ask spread and the independent variables are various measures of the quality of Internal Control over Financial Reporting (ICFR) in addition to a set of control variables. I also classify Internal Control Deficiencies into different types of weaknesses, in terms of severity and examine the impact of the remediation of IC weaknesses on information asymmetry. Taken together, I measure ineffective internal control by the presence of Internal Control Deficiencies (ICDs) under sections 302 and 404 I measure ineffective IC using both the level of severity of a deficiency and the remediation actions to address disclosed IC weaknesses. The level of ineffective IC will be operationalized by different types of IC weaknesses in terms of severity (e.g., company-level versus account-specific weaknesses). The change in IC weaknesses will be measured by whether firms took remediation actions to correct these weaknesses.

\subsubsection{Dependent Variable}

My dependent variable in all tested models is information asymmetry (IA) $)^{22}$. I use the bid-ask spread as one important microstructure measure of information asymmetry that has been used extensively in prior literature as a proxy for information asymmetry in the secondary loan market (Moerman, 2008; Frankel and Li, 2004; Sufi, 2007; Bharath, Pasquariello, and Wu, 2008.) The bid-ask spread consists of three primary components: order processing, inventory,

\footnotetext{
${ }^{22}$ I use the log transformation of the bid-ask spread to correct for skewness.
} 
and adverse selection (Bharath, Pasquariello, and $\mathrm{Wu}, 2008$ ). The market microstructure measures of information asymmetry capture the adverse selection between informed and uninformed traders. The adverse selection component of information asymmetry affects the price formation because, by definition, the presence of adverse selection implies that informed traders possess more information than that possessed by uninformed traders.

Moerman (2008) suggests that the use of the bid-ask spread might be problematic because it includes an adverse selection component and a transitory component. The adverse selection component is the asymmetric information, and the transitory component is the inventory and order processing costs of market makers that can be measured by the number of market makers and could be endogenously associated with the IA. Information asymmetry is the adverse selection component in the bid-ask spread.

While controlling for the temporary component in the bid-ask spread was not feasible, I made every effort to try to fully explain the permanent components, which cause the adverse selection and asymmetric information portion in the bid-ask spread by adding a large pool of loan-specific characteristics to the regression models. I use the loan-specific characteristics to proxy for the permanent components in the bid-ask spread because loan characteristics are set at the beginning of the loan contract and arrangements are usually made over a longer time period. The unexplained portion in the bid-ask spread should be attributed to the temporary components, the inventory and order processing costs of market makers.

\subsubsection{Independent Variable}

The independent variable in model 1 and 2 is the disclosure of the quality of ICFR. In model 1 , I measure the quality of IC by an indicator variable that takes a value of 1 if the firm discloses Internal Control Deficiencies (ICDs) and 0 otherwise (Hla, model 1). I also test the 
association between the disclosure of only ICDs under provisions, section 302 and section 404, and information asymmetry (H1b, model 2). I then measure the effect of the severity of IC weaknesses, as measured by the disclosure of ICMWs (H2a, model 3) and information asymmetry. In model 4, I measure the effect of the severity of Internal Control Deficiencies as measured by the disclosure of Company Level (CL) IC weaknesses and information asymmetry $(H 2 b$, model 4$)$. I finally test the impact of IC remediation ${ }^{23}$, change in ICDs, on information asymmetry (H3, model 5). The mediating effect of the loan-specific characteristics on the association between ICDs and IA is presented in model 6 (H4, model 6).

\subsubsection{Control variables}

Recall that the disclosure of IC quality is a selective disclosure that is disseminated to market-wide participants. I then expect that a set of control variables might have significant positive or negative impact on information asymmetry. Therefore, I control for these potential explanatory variables in my model to avoid having omitted correlated variables in my model, to increase the validity of my results, and to be able to generalize my results. Additionally, I use a set of control variables from prior research that explain some of the variations in information asymmetry. For example, I control for firm-specific characteristics (e.g., ROA, loss, profitability, firm size, growth, industry), loan-specific characteristics (e.g., types of loans, maturity, loan credit rating, identity of lenders, loan size, debt covenants, purpose of loans), regulations (e.g.,

\footnotetext{
${ }^{23}$ Remediation can be captured by SOX section 404 unqualified opinion or (Goh, 2009; Ashbaugh-Skaife et al., 2008), the difference in the indicator variable in year $t+1$ or $\mathrm{t}-1$ and the indicator variable in year $t$ as suggested by (Feng, Li and McVay, 2009), or remediation actions by the management (Ashbaugh-Skaife, Collins, Kinney, and LaFond, 2008). I followed Feng et al. (2009) in identifying firms that took remediation actions to correct their internal control deficiencies. I only include firms that took serious steps to correct their internal control deficiencies. For example, in period t-1, a firm might disclose internal control deficiencies related to competency of their human resources, merger and acquisition and foreign-related issues. In period $t$, the same firm might disclose internal control deficiencies related to only merger and acquisition. In this latter case, the firm partially remediated their internal control deficiencies and I considered this case "remediation". Alternatively, in period t, the firm might disclose effective internal control system and in this case, the firm fully remediated their internal control deficiencies and I considered this case "remediation". Although there could be some firms in the process of remediating their internal control deficiencies and firms include such statements in their financial statements to outsiders, I considered this disclosure as if firms did not take any remediating actions yet to correct the internal control deficiencies.
} 
SOX 2002 - IC related provisions, regulated industries), financial reporting quality (e.g., accounting accruals, Big $6^{24}$ audit firms, auditor change "resignation and dismissal"), determinants of the bid-ask spread (e.g., liquidity as measured by amount or volume of stock traded, and volatility or market risk).

I use Big 6 audit firms instead of Big 4 because after the passage of SOX 2002, big audit firms are continuously calling for more protection to reduce their litigation risk. This call is not only restricted to Big 4 audit firms, namely, KPMG, Deloitte, Ernst \& Young, PricewaterhouseCoopers, but also extends to other non-Big 4 firms such as the second-tier audit firms such as: BDO Seidman and Grant Thornton (Blokdijk, Drieenhuizen, Simunic, and Stein, 2006). Additionally, It is argued that the second-tier audit firm have become more conservative and non-tolerant to earnings management post SOX 2002 (Krishnan, Park, and Vijayakumar, 2008). Big 4 audit firms rejected risky firms post SOX 2002 and these risky firms selected the next two largest audit firms (Turner, 2010). Overall, the second-tier audit firms are of increased value post SOX 2002 because they probably provide quality services and lower cost relative to Big 4 firms. Therefore, I use the Big 6 audit firms (Big 4 and second tier audit firms) instead of the Big 4 audit firms because of the systematic evidence in the literature that audit quality differs significantly between Big and non-Big audit firms (Blokdijk, Drieenhuizen, Simunic, and Stein, 2006) as well as the increased quality of second tier audit firms post SOX 2002.

\footnotetext{
${ }^{24}$ The Big-6 audit firms include: Deloitte, KPMG, Ernst \& Young, PricewaterhouseCoopers, BDO Seidman and Grant Thornton.
} 


\section{Firm-Specific Characteristics}

The pecking order theory of capital structure of Myers (1984) and Myers and Majluf (1984) predicts that information asymmetry associated with stock issuance is higher than that associated with bank or public debt. Firm specific characteristics include firm size, market-tobook 'growth ratio', debt covenants, and R\&D. Firms with debt are characterized by fewer growth opportunities (as measured by Tobin's Q), as implied by the pecking order theory (Bharath, Pasquariello, and Wu, 2008). Brown and Hillegiest (2007) find the effect of disclosure quality on information asymmetry varies across firms, industries and even within firms (quarterly versus annual reports). Among the factors that directly affect the quality of internal control is corporate governance (Haron, Ibrahim, Jeyaraman, and Chye, 2010) but I did not have access to related corporate governance data to my study sample period.

\section{Loan-Specific Characteristics}

Moerman (2008) and Sufi (2007) find that loans of profit, public firms, with available credit ratings, or syndicated by reputable arrangers are traded at low bid-ask spreads. Likewise, Moerman (2008) finds that distressed loans and revolvers loans and loans issued by institutional investors are traded at high bid-ask spread. While I do not have access to the reputation of the arranger, I include other available variables such as: credit rating, syndication, loan types and identity of lenders among others, as control variables in my regression model.

Among the set of control variables that might affect the information asymmetry in the secondary loan market are: private versus public traders (borrowers), loan-specific credit rating, loan size, revolving versus term loans, profitable versus loss firms, and the arrangers' reputation. Sufi (2007) finds that borrower and lead bank reputation mitigates, but does not eliminate, information asymmetry in the secondary loan market. 
Measures of the arranger's reputation include: 1) an estimation of the arranger's market share in the primary market, and 2) an estimation that accounts for the total market share of all the arrangers involved in the loan (in the case of multiple arrangers). I could not have access to the reputation of the arranger but I added a variable to represent the identity of the lender, whether it is a bank or financial institution. I also control for various types and purposes of loan.

\section{Financial Reporting Quality}

Moerman (2008) finds that timely loss recognition reduces information asymmetry in the secondary loan market. In other words, timely loss recognition increases debt contracting efficiency and reduces the agency cost through underestimating the net asset value and hence facilitating monitoring by debt holders. The market response to IC quality is also dependent on audit quality (Gupta and Nayar, 2006; Beneish et al., 2008). Therefore, a measure of financial reporting quality is added to the model. I use accounting accruals as a measure of financial reporting quality.

\section{Determinants of the bid-ask spread}

Determinants of the bid-ask spread are liquidity (amount or volume of stock traded), and volatility or market risk. Liquidity is argued to be negatively associated with information asymmetry and the cost of capital (Botosan, 1997; Diamond and Verrecchia, 1991; Healy, Hutton, and Palepu, 1999; Leuz and Verrecchia, 2000; Botosan and Plumlee, 2002). Therefore, I control for liquidity in my model.

\subsubsection{Empirical Models and Tests for Hypothesis}

In this section, I describe my research models, which are used to test my hypothesized relationships. My first hypothesis deals with the relationship between the disclosure of Internal Control Deficiencies (ICDs) and information asymmetry (IA) in the secondary loan market. I use 
two models (models 1 and 2) to test my first hypothesis. In model 1, I use ICDs (firms that disclosed significant deficiency, control deficiency, and/or MWs under section 302) and ICMWs (firms that disclosed MWs under section 404) as proxies for IC weaknesses as the independent variable, and information asymmetry as the dependent variable. In all models, I also use a set of control variables that explain information asymmetry as described in the previous section. Models 1 and 2 are described below:

$$
\text { Ln_IA }{ }_{\text {it }}=\beta_{0}+\beta_{1} \mathrm{ICDs}_{\mathrm{it}}+\sum_{i=1}^{j} \alpha_{\mathrm{j}} \delta_{\mathrm{it}}+\varepsilon_{\mathrm{t}}
$$

Where

Ln_IA ${ }_{\text {it }}=$ is natural logarithm of information asymmetry as measured by the bid-ask spread in the secondary loan market.

$\mathrm{ICDs}_{\mathrm{it}}=$ is an indicator variable equals 1 if the firm disclosed any types of Internal Control Deficiencies, zero otherwise.

$\delta_{\text {it }}=$ is a set of control variables that explain the variation in IA in prior research.

In model 2, I compare the effect of the disclosure of ICDs under section 302 versus section 404 on IA. Therefore, I use an indicator variable as my independent variable in model 2. This indicator variable $=1$ if the firm has ICDs reported under section 302 , zero for the presence of ICDs reported under section 404. I also add a set of control variables that explain information asymmetry. Model 2 is described below:

$$
\mathrm{Ln} \_\mathrm{IA}_{\mathrm{it}}=\beta_{0}+\beta_{1} \mathrm{ICDs} \_302_{\mathrm{it}}+\sum_{i=1}^{j} \alpha_{\mathrm{j}} \delta_{\mathrm{it}}+\varepsilon_{\mathrm{t}}
$$

Where

Ln_IA ${ }_{i t}=$ is natural logarithm of information asymmetry as measured by the bid-ask spread in the secondary loan market.

ICDs_302 $2_{\text {it }}=$ is an indicator variable equals 1 if the firm disclosed Internal Control Defectiveness (ICDs) under section 302, zero otherwise.

$\delta_{\text {it }}=$ is a set of control variables that explain the variation in IA in prior research. 
I use model 3, and 4 to test my second hypothesis. In these models, I classify IC weaknesses into its components in terms of severity. I use two classifications of IC weaknesses severity, AS 2 (material weaknesses versus other deficiency) and company-level versus accounting-specific. In an extended analysis, I test the effect of the interaction term of loanspecific characteristics (syndication, credit rating and covenants) and ICDs on the association between ICDs and IA. I use IA as my dependent variable in all models and I use the set of control variables, firm and loan specific characteristics, previously discussed as my independent variables.

I use the AS 2 classification of the severity of ICMWs; therefore, I use ICMWs reported under both section 302 and section 404 as my variable of interest. Model 3 is described below.

$$
\mathrm{Ln} \_\mathrm{IA}_{\mathrm{it}}=\beta_{0}+\beta_{1} \mathrm{ICMW}_{\mathrm{it}}+\sum_{i=1}^{j} \alpha_{\mathrm{j}} \delta_{\mathrm{it}}+\varepsilon_{\mathrm{t}} \quad \text { (Model 3) }
$$

Ln_IA ${ }_{\text {it }}=$ is natural logarithm of information asymmetry as measured by the bid-ask spread in the secondary loan market.

ICMWs $_{\text {it }}=$ is an indicator variable that equals 1 if the firm disclosed ICMWs under section 302 or section 404, zero otherwise.

$\delta_{\text {it }}=$ is a set of control variables that explain the variation in IA in prior research.

I hence use company-level versus account-specific classification of the severity of IC weakness. I, therefore, use an indicator variable that equals 1 if the IC weaknesses affect the company level and zero otherwise. My dependent variable is information asymmetry measured by the bid-ask spread. A set of control variables are also added to model 4.

$$
\mathrm{Ln} \_\mathrm{IA}_{\mathrm{it}}=\beta_{0}+\beta_{1} \mathrm{CL}_{\mathrm{it}}+\sum_{i=1}^{j} \alpha_{\mathrm{j}} \delta_{\mathrm{it}}+\varepsilon_{\mathrm{t}}
$$

To mitigate the problem of omitted correlated variables, I follow Feng et al. (2009) by doing both level and change analysis and further conducting a cross-section analysis based on the 
types of ineffective internal control quality. I then test for changes in the quality of internal control (Hypothesis 3) due to the management and/or auditors remediation actions.

I use model 5 to test my third hypothesis, which predicts a significant negative association between the disclosure of the remediation of Internal Control Deficiencies and the average bid-ask spread.

The change in IC weaknesses can be measured as the difference in the indicator variable in year $t+1$ or $\mathrm{t}-1$ and the indicator variable in year $t$ as suggested by (Feng, Li and McVay, 2009), or by auditor opinion, an adverse audit opinion is an indication of negative change in IC weaknesses and an unqualified opinion is an indication of positive change in IC weaknesses or remediation actions by the management (Ashbaugh-Skaife, Collins, Kinney, and LaFond, 2008). I use model 5 to test my third hypothesis. The dependent variable is IA and the independent variables are the change in material weaknesses or remediation (REM) as a proxy for remediation as well as the set of control variables. The change in material weaknesses is measured as an indicator variable $=1$ if the firm remediated part or all the disclosed IC weaknesses in the year t-1, zero otherwise. I also use the set of control variables I previously discussed. In model 5, I expect a negative significant association from the regression of changes in IC weakness (remediation) on information asymmetry. Model 5 is described below:

$$
\text { Ln_IA }{ }_{i t}=\beta_{0}+\beta_{1} \mathrm{REM}_{\mathrm{it}}+\sum_{i=1}^{j} \alpha_{\mathrm{j}} \delta_{\mathrm{it}}+\varepsilon_{\mathrm{t}}
$$

Where

Ln_IA it $=$ is natural logarithm of information asymmetry as measured by the bid-ask spread in the secondary loan market.

$\mathrm{REM}_{\mathrm{it}}=$ is an indicator variable equal 1 if the firm remediated part or all the disclosed IC weaknesses in the year $\mathrm{t}-1$, zero otherwise.

$\delta_{\text {it }}=$ is a set of control variables that explain the variation in IA in prior research.

In model 6 , I test the effect of the secondary loan market unique characteristics on mitigating the positive hypothesized relationship between the disclosure of ICDs and IA. I then 
test the interaction term between ICDs and syndication, credit rating, and covenants and IA. I will run three regression models to test $\mathrm{H} 4$ based on model 3 by using syndication, credit rating and covenants as interaction term with ICDs. I also add a set of control variables that explain information asymmetry. Model 3 is described below:

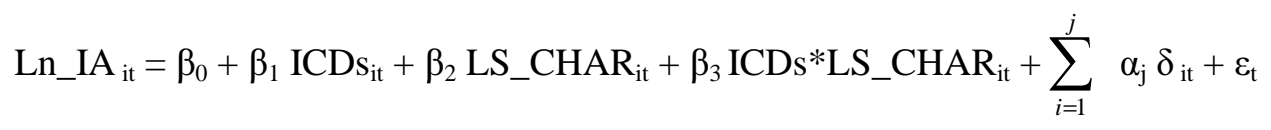

Where

Ln_IA ${ }_{i t}=$ is natural logarithm of information asymmetry as measured by the bid-ask spread in the secondary loan market.

$\mathrm{ICDs}_{\mathrm{it}}=$ is an indicator variable equals 1 if the firm disclosed any types of Internal Control Deficiencies, zero otherwise.

LS_CHAR ${ }_{i t}=$ syndication or number of lenders, the availability of credit rating and the existence of debt covenants. ${ }^{25}$

ICDs*LS_CHAR ${ }_{\mathrm{it}}=$ the interaction term between LS_CHAR ${ }_{\mathrm{it}}$ and ICDs*LS_CHAR it

$\delta_{i t}=$ is a set of control variables that explain the variation in IA in prior research.

\footnotetext{
${ }^{25}$ I use three separate regression model to test the interaction effect of the loan specific characteristics and ICDs on the association between the ICDs and information asymmetry
} 


\section{CHAPTER 6}

\section{EMPIRICAL RESULTS AND ANALYSIS}

\subsection{Sample Size and Selection}

I tested the sample period post SOX 2002 - IC provisions. I started with and used a sample of available secondary loan market data from 2002-2005. Secondary loan market data post 2005 is not accessible to me. While data after 2005 is not possible to obtain, future research might extend my study by extending my sample period. The sample is then restricted to only four years because of limited access to the secondary loan market data post 2005.

I obtained data for firms with effective versus deficient internal control and other proxies for the quality of internal control over financial statement (e.g., significant deficiency, and remediation of Internal Control Deficiencies) from AUDIT ANALYSTCIS (AA). I relied solely on AA to get internal control data due to the reliability of AA and its wide use by prominent researchers, relative to the limited use of the Compliance Week. Additionally, Irving (2006) points out to the potential selection bias and external validity issues associated with Compliance Week because it does not represent the population of firms with ICMWs. I used my proxies for information asymmetry (Bid-Ask Spread) and loan-specific characteristics from DealScan or Loanware database $^{26}$. I used COMPUSTAT to get my control variables that represent the firmspecific characteristics such as: ROA, Assets, and Liquidity, Discretionary Accruals, MTB, and Loss firms.

I started with 3971 firm-year facilities ${ }^{27}$ or observations of the secondary loan data that covered the period from 2004-2005. I removed 341 firm-year observations belonging to

\footnotetext{
${ }^{26}$ Professor Kenneth Daniels, a professor of finance at Virginia Commonwealth University has shared the DealScan or Loanware database with me.

${ }^{27}$ Facility is a loan granted to a firm. A firm might have a number of facilities during one accounting period.
} 
international firms. The remaining sample is 3630 firm-year observations for U.S. firms postSOX 2002 to 2005. I manually inserted the key identifiers such as: CUSIP and CIK to the secondary loan market data to merge it with other databases such as COMPUSTAT and AA. I obtained discretionary accrual data from COMPUSTAT and estimated the discretionary accrual according to Dechow, Sloan, and Sweeney (1995), I further winzorized my discretionary accrual data at $10 \%$. I then merged the discretionary accrual data with the secondary loan market data after replacing some missing firm-years observations for discretionary accrual data with the mean of the available accruals data (estimated to be 0.05 ) and I merged the two datasets based on the GVKEY and fiscal year (FYEAR). The sample after the merge is 3630 firm-years observations.

I obtained the internal control data such as material weaknesses, significant deficiencies, and effective internal control from the AA database for 2002-2005. I searched AA for disclosure control data for accelerated filers firms (firms with more than $\$ 75$ million market capitalization.) The internal control sample is 16383 firm-year observations. I obtained the audit characteristics information for the same sample period, such as auditor name, auditor resignation and/or dismissal from AA database. The audit characteristics sample is 13041 firm-year observations. I also obtained the control variables such as: ROA, MTB, ASSETS ${ }^{28}$, and LOSSES firms from COMPUSTAT database. The sample of the control variable is 5384 firm-year observations.

I merged the internal control data with the control variable data and audit characteristics data based on the CIK and fiscal year (FYEAR). I completed the merge using ACCESS. The merge of these three datasets resulted in 3467 firm-years observations. Finally, I merged the 3467 firm-years observations with the discretionary accruals and secondary loan market data

\footnotetext{
${ }^{28}$ I used the log transformation for key variables such as: Assets, CFO, and Loan size to correct for skewness.
} 
(3630 firm-years observations). I merged the two datasets based on the CIK and fiscal year (FYEAR). The final sample after the merge is 533 (1802) firms (firm-years observations.)

I then classified the material weaknesses into Company Level (CL), Account Specific (AS) and further coded firms that remediated part of or all Internal Control Deficiencies in the following accounting period. In categorizing the Internal Control Deficiencies as either CL or AS, I classified weaknesses in internal control related to any accounts such as: inventory, accounts receivables, loan receivables, gain or loss recognition issues, liabilities, reserves, tax expense, depreciation, depletion or amortization issues, and financial derivatives as AS weaknesses in internal control. Similarly, I classified weaknesses in internal control related to company level issues such as: acquisition, merger, disposal or reorganization issues deferred, stock-based or executive compensation issues, intercompany issues, foreign-related party, consolidation, affiliated and/or subsidies issues as CL weaknesses in internal control. I then manually coded firms with CL with 1 and firms with AS with zero.

I also manually coded firms that remediated part or all weaknesses in internal control from year $t-1$ to year $t$ with 1 and firms that did not remediate Internal Control Deficiencies with zero. The variables definitions and measurement used in the statistical analysis are listed in Appendix A. Table 6 summarizes the steps taken to reach the final sample after merging various databases. My final sample consists of 553 (1802) firms (facilities) from 2002-2005. This final sample includes firms with ICDs as well as firms with effective IC systems. Out of the 553 (1802) firms (facilities), 81(398) firms (facilities) are having ICDs and the rest of the sample 472 (1404) firms (facilities) are firms with effective IC. The effective IC sample is used as the control sample in my statistical analysis. 
My final sample represents a wide-variety of sectors in the economy. Table 7 lists sample firms by industry categories. Almost one third, 184 (or 33.27\%) of my sample firms are manufacturing firms. The second most represented category is Finance, Insurance, and Real Estate, where it represents 109 firms (or 19.71\%), almost one fifth of my sample. Transportation, Communication and utilities is represented by $79(14.29 \%)$ of my sample. Other included sectors are Service Industries 76 (13.74), Retail Trade 43 (7.78\%), Mineral Industries 38 (6.87\%), Wholesale Trade 13 (2.35\%) and Construction Industries 11 (1.99). 
TABLE 6

Final Sample

\begin{tabular}{|c|c|c|}
\hline Industry & \# Firms & \# Observations \\
\hline The secondary loan market Data & 1968 & 3971 \\
\hline (-) The secondary loan market for Non-U.S. Firms & $(196)$ & $(341)$ \\
\hline$=$ The secondary loan market Data for only U.S. Firms & 1772 & 3630 \\
\hline \multicolumn{3}{|c|}{ (-) Internal Control and Control data not available in either COMPUSTAT and/or } \\
\hline Audit Analytics & $(1219)$ & $(1828)$ \\
\hline = Final full sample (including control sample) & 553 & 1802 \\
\hline (-) Firms with no ICDs (control sample) & $(472)$ & $(1404)$ \\
\hline = Final sub-sample including only ICDs firms (treatment sample) & 81 & 398 \\
\hline
\end{tabular}


TABLE 7

Sample Distribution by Industry Type

\begin{tabular}{llllll}
\hline Industry & Codes & \# Firms & \% Firms & \# Obs. & \% Obs. \\
\hline Mineral Industries & 12,13 & 38 & $6.87 \%$ & 124 & $6.88 \%$ \\
Construction Industries & $15-17$ & 11 & $1.99 \%$ & 56 & $3.11 \%$ \\
Manufacturing & $20,22,24-30,32-39$ & 184 & $33.27 \%$ & 622 & $34.52 \%$ \\
Transportation, Communication, and Utilities & $40,42,45,47-49$ & 79 & $14.29 \%$ & 303 & $16.81 \%$ \\
Wholesale Trade & 50,51 & 13 & $2.35 \%$ & 32 & $1.78 \%$ \\
Retail Trade & $52-59$ & 43 & $7.78 \%$ & 128 & $7.10 \%$ \\
Finance, Insurance, and Real Estate & $60-65,67$ & 109 & $19.71 \%$ & 317 & $17.59 \%$ \\
Service Industries & $70,73,78,79,80,82,87$ & 76 & $13.74 \%$ & 220 & $12.21 \%$ \\
\cline { 2 - 6 } & & $\mathbf{5 5 3}$ & $100 \%$ & $\mathbf{1 8 0 2}$ & $100 \%$ \\
\hline \hline
\end{tabular}




\subsection{Descriptive Statistics}

The descriptive statistics of the final sample of 533 firms (1802 firm-years observations) are shown in table 8 . Table 8 consists of three panels with a decomposed full sample (1802 firmyear facilities) into ICDs (398 firms) and effective IC samples (1404 firms). Panel A summarizes the descriptive statistics for the variables of interests such as the bid-ask spread and Internal Control Deficiencies variables. Panel B demonstrates the descriptive statistics of the firmspecific characteristics. Panel C lists the summary statistics of the loan specific characteristics.

As shown in panel A, the bid-ask spread for the full sample ranges from 10 to 975 basis points with standard deviation of 124.3958. The average (median) bid-ask spread for firms with ICDs 198.7764 (175) is higher than that for firms with effective IC 160.0974 (137.5). ICDs (ICMWs) represent $22.09 \%(20.20 \%)$ of the total sample. Out of the $20.20 \%$ firms with ICMWs in the full sample, $1.44 \%(18.76 \%)$ is firms with ICMWs reported under section 302 (404). For the ICDs sample, $91.46 \%$ are firms with ICMWs. The majority of ICMWs (87\%) seems to be clustered post section 404 of the ICDs sample. $33.17 \%$ of the ICDs sample are firms with CL internal control and $20.60 \%$ are firms that took remediation actions from year $t-1$ to year $t$ to correct the documented deficiency in their internal control system.

Panel B of table 8 shows summary statistics of the firm-specific characteristics of the full sample and its decompositions of ICDs and effective ICs. As expected, the comparison of the firm-specific characteristics of the firms with ICDs versus firms with effective IC shows that firms with ICDs have lower ROA, Assets size, and liquidity. ICDs firms also experience, on average, high auditor resignation, less audit involvement from Big 6 firms, and more loss firms than firms with effective ICDs. On average, $20.31 \%$ of the full sample firms are post section 404. 
Overall, the descriptive statistics of firms with ICDs in panel B reveal that firms with reported ICDs are generally smaller, poorer performers, and financially weaker, with higher market risk. These results are consistent with and documented by numerous studies(Bryan and Lilien, 2005; Ge and McVay, 2005; Doyle, Ge and McVay 2007 a,b; Ashbaugh-Skaife, Collins, and Kinney, 2007, Ashbaugh-Skaife, Collins, Kinney, and LaFond, 2008).

Panel C lists the summary statistics of the loan-specific characteristics. It shows that firms with ICDs are composed of lower percentage (12.60\%) of short-term revolvers loan than firms with effective IC (29.13\%). 9\% of the ICDs firms are loans by institutional investors compared to $6.84 \%$ for effective ICDs firms. However, $3.5 \%$ of ICDs firms are loans by banks compared to $1.78 \%$ loans financed by banks for effective IC sample. $36.13 \%$ of the full sample is corporate purpose loans. On average, firms with ICDs sample are less $\operatorname{rated}^{29}(2.8)$ by credit agencies than effective IC sample firms (2.4). On average, $68.04 \%$ of the full sample has debt covenants but ICDs firms have higher debt covenants, $72 \%$, compared to $66.95 \%$, for firms with effective IC.

\footnotetext{
${ }^{29}$ The rating categories are three levels: 1,2 and 3. The level 1 category indicates a high credit rating and a level 3 category indicates a lower credit rating.
} 
TABLE 8

Descriptive Statistics

\begin{tabular}{|c|c|c|c|c|c|c|c|c|c|c|}
\hline & Mean & Med. & Std. & Min. & \multirow[t]{3}{*}{ Max. } & \multirow[t]{3}{*}{ Mean } & Med. & Std. & Min. & \multirow[t]{3}{*}{ Max. } \\
\hline & & \multicolumn{3}{|c|}{ Full sample $N=1802$} & & & \multicolumn{3}{|c|}{ ICDs sample $N=398$} & \\
\hline \multicolumn{8}{|c|}{ Panel A: Variables of Interest } & & & \\
\hline IA & 168.6403 & 150.0000 & 124.3958 & 10.0000 & 975.0000 & 198.7764 & 175.0000 & 119.7335 & 18.0000 & 650.0000 \\
\hline ICDs & 0.2209 & 0.0000 & 0.4149 & 0.0000 & 1.0000 & 1.0000 & 1.0000 & 0.0000 & 1.0000 & 1.0000 \\
\hline ICMWs & 0.2020 & 0.0000 & 0.4016 & 0.0000 & 1.0000 & 0.9146 & 1.0000 & 0.2799 & 0.0000 & 1.0000 \\
\hline ICMWs_302 & 0.0144 & 0.0000 & 0.1193 & 0.0000 & 1.0000 & 0.0402 & 0.0000 & 0.1967 & 0.0000 & 1.0000 \\
\hline ICMWs_404 & 0.1876 & 0.0000 & 0.3905 & 0.0000 & 1.0000 & 0.8744 & 1.0000 & 0.3318 & 0.0000 & 1.0000 \\
\hline $\mathrm{CL}$ & 0.0733 & 0.0000 & 0.2606 & 0.0000 & 1.0000 & 0.3317 & 0.0000 & 0.4714 & 0.0000 & 1.0000 \\
\hline REM & 0.0455 & 0.0000 & 0.2085 & 0.0000 & 1.0000 & 0.2060 & 0.0000 & 0.4050 & 0.0000 & 1.0000 \\
\hline \multicolumn{11}{|c|}{ Panel B: Firm -Specific Characteristics } \\
\hline ROA & 0.0126 & 0.0269 & 0.1472 & -1.0092 & 2.3157 & -0.0151 & 0.0033 & 0.1669 & -0.3232 & 1.4805 \\
\hline ASSETS & 21.2479 & 21.1311 & 1.6013 & 16.6603 & 26.8993 & 20.9555 & 20.7645 & 1.3289 & 18.7340 & 25.5792 \\
\hline MTB & 1.0937 & 0.8969 & 1.1339 & -3.6942 & 8.1910 & 1.2656 & 1.4080 & 1.0315 & -1.1568 & 3.6010 \\
\hline DA & 0.1026 & 0.0089 & 0.6625 & -2.7740 & 5.4347 & 0.0069 & 0.0082 & 0.5604 & -2.3169 & 2.3082 \\
\hline REG & 0.2647 & 0.0000 & 0.4413 & 0.0000 & 1.0000 & 0.1457 & 0.0000 & 0.3533 & 0.0000 & 1.0000 \\
\hline LQ & 4.1862 & 4.0527 & 1.2104 & 0.0000 & 7.9959 & 3.8847 & 3.8456 & 1.0864 & 0.0000 & 6.4264 \\
\hline LOSS & 0.5610 & 1.0000 & 0.4964 & 0.0000 & 1.0000 & 0.6935 & 1.0000 & 0.4616 & 0.0000 & 1.0000 \\
\hline AUD_D & 0.1138 & 0.0000 & 0.3176 & 0.0000 & 1.0000 & 0.0553 & 0.0000 & 0.2288 & 0.0000 & 1.0000 \\
\hline AUD_R & 0.0139 & 0.0000 & 0.1170 & 0.0000 & 1.0000 & 0.0503 & 0.0000 & 0.2187 & 0.0000 & 1.0000 \\
\hline BIG_6 & 0.9856 & 1.0000 & 0.1193 & 0.0000 & 1.0000 & 0.9648 & 1.0000 & 0.1845 & 0.0000 & 1.0000 \\
\hline SOX 404 & 0.2031 & 0.0000 & 0.4024 & 0.0000 & 1.0000 & 0.9196 & 1.0000 & 0.2723 & 0.0000 & 1.0000 \\
\hline
\end{tabular}


TABLE 8 (Concluded)

Descriptive Statistics

\begin{tabular}{|c|c|c|c|c|c|c|c|c|c|c|}
\hline & Mean & Med. & Std. & Min. & \multirow[t]{2}{*}{ Max. } & \multirow[t]{2}{*}{ Mean } & Med. & Std. & Min. & \multirow[t]{2}{*}{ Max. } \\
\hline & & \multicolumn{3}{|c|}{ ICDs sample $N=398$} & & & \multicolumn{3}{|c|}{ Effective IC sample $N=1404$} & \\
\hline IA & 198.7764 & 175.0000 & 119.7335 & 18.0000 & 650.0000 & 160.0974 & 137.5000 & 124.4056 & 10.0000 & 975.0000 \\
\hline ICDs & 1.0000 & 1.0000 & 0.0000 & 1.0000 & 1.0000 & 0.0000 & 0.0000 & 0.0000 & 0.0000 & 0.0000 \\
\hline ICMWs & 0.9146 & 1.0000 & 0.2799 & 0.0000 & 1.0000 & 0.0000 & 0.0000 & 0.0000 & 0.0000 & 0.0000 \\
\hline ICMWs_302 & 0.0402 & 0.0000 & 0.1967 & 0.0000 & 1.0000 & 0.0000 & 0.0000 & 0.0000 & 0.0000 & 0.0000 \\
\hline ICMWs_404 & 0.8744 & 1.0000 & 0.3318 & 0.0000 & 1.0000 & 0.0000 & 0.0000 & 0.0000 & 0.0000 & 0.0000 \\
\hline CL & 0.3317 & 0.0000 & 0.4714 & 0.0000 & 1.0000 & 0.0000 & 0.0000 & 0.0000 & 0.0000 & 0.0000 \\
\hline REM & 0.2060 & 0.0000 & 0.4050 & 0.0000 & 1.0000 & 0.0000 & 0.0000 & 0.0000 & 0.0000 & 0.0000 \\
\hline \multicolumn{11}{|c|}{ Panel B: Firm -Specific Characteristics } \\
\hline ROA & -0.0151 & 0.0033 & 0.1669 & -0.3232 & 1.4805 & 0.0204 & 0.0311 & 0.1402 & -1.0092 & 2.3157 \\
\hline ASSETS & 20.9555 & 20.7645 & 1.3289 & 18.7340 & 25.5792 & 21.3308 & 21.2352 & 1.6616 & 16.6603 & 26.8993 \\
\hline MTB & 1.2656 & 1.4080 & 1.0315 & -1.1568 & 3.6010 & 1.0450 & 0.7958 & 1.1569 & -3.6942 & 8.1910 \\
\hline DA & 0.0069 & 0.0082 & 0.5604 & -2.3169 & 2.3082 & 0.1297 & 0.0125 & 0.6865 & -2.7740 & 5.4347 \\
\hline REG & 0.1457 & 0.0000 & 0.3533 & 0.0000 & 1.0000 & 0.2984 & 0.0000 & 0.4577 & 0.0000 & 1.0000 \\
\hline LQ & 3.8847 & 3.8456 & 1.0864 & 0.0000 & 6.4264 & 4.2717 & 4.1606 & 1.2302 & 0.0000 & 7.9959 \\
\hline LOSS & 0.6935 & 1.0000 & 0.4616 & 0.0000 & 1.0000 & 0.5235 & 1.0000 & 0.4996 & 0.0000 & 1.0000 \\
\hline AUD_D & 0.0553 & 0.0000 & 0.2288 & 0.0000 & 1.0000 & 0.1303 & 0.0000 & 0.3368 & 0.0000 & 1.0000 \\
\hline AUD_R & 0.0503 & 0.0000 & 0.2187 & 0.0000 & 1.0000 & 0.0036 & 0.0000 & 0.0596 & 0.0000 & 1.0000 \\
\hline BIG_6 & 0.9648 & 1.0000 & 0.1845 & 0.0000 & 1.0000 & 0.9915 & 1.0000 & 0.0921 & 0.0000 & 1.0000 \\
\hline SOX 404 & 0.9196 & 1.0000 & 0.2723 & 0.0000 & 1.0000 & 0.0000 & 0.0000 & 0.0000 & 0.0000 & 0.0000 \\
\hline
\end{tabular}


TABLE 8 (Concluded)

Descriptive Statistics

\begin{tabular}{|c|c|c|c|c|c|c|c|c|c|c|}
\hline & \multirow[t]{2}{*}{ Mean } & Med. & Std. & Min. & \multirow[t]{2}{*}{ Max. } & \multirow[t]{2}{*}{ Mean } & Med. & Std. & Min. & \multirow[t]{2}{*}{ Max. } \\
\hline & & \multicolumn{3}{|c|}{ Full sample $N=1802$} & & & \multicolumn{3}{|c|}{ ICDs sample $N=398$} & \\
\hline S_REVOLVERS & 0.2547 & 0.0000 & 0.4358 & 0.0000 & 1.0000 & 0.1260 & 0.0000 & 0.3318 & 0.0000 & 1.0000 \\
\hline L_REVOLVERS & 0.5277 & 1.0000 & 0.4994 & 0.0000 & 1.0000 & 0.6130 & 1.0000 & 0.4877 & 0.0000 & 1.0000 \\
\hline BANK_LENDERS & 0.0216 & 0.0000 & 0.1456 & 0.0000 & 1.0000 & 0.0350 & 0.0000 & 0.1845 & 0.0000 & 1.0000 \\
\hline INSTIT_LENDERS & 0.0733 & 0.0000 & 0.2606 & 0.0000 & 1.0000 & 0.0900 & 0.0000 & 0.2872 & 0.0000 & 1.0000 \\
\hline CAP & 0.0117 & 0.0000 & 0.1074 & 0.0000 & 1.0000 & 0.0000 & 0.0000 & 0.0000 & 0.0000 & 0.0000 \\
\hline CORP & 0.3613 & 0.0000 & 0.4805 & 0.0000 & 1.0000 & 0.5100 & 1.0000 & 0.5010 & 0.0000 & 1.0000 \\
\hline CP_PACKUP & 0.1443 & 0.0000 & 0.3515 & 0.0000 & 1.0000 & 0.0600 & 0.0000 & 0.2380 & 0.0000 & 1.0000 \\
\hline DEBT & 0.0660 & 0.0000 & 0.2484 & 0.0000 & 1.0000 & 0.0600 & 0.0000 & 0.2380 & 0.0000 & 1.0000 \\
\hline TAKEOVER & 0.0427 & 0.0000 & 0.2023 & 0.0000 & 1.0000 & 0.0500 & 0.0000 & 0.2190 & 0.0000 & 1.0000 \\
\hline OTHER_LOANS & 0.0316 & 0.0000 & 0.1751 & 0.0000 & 1.0000 & 0.0200 & 0.0000 & 0.1220 & 0.0000 & 1.0000 \\
\hline SECURED & 0.4362 & 0.0000 & 0.4960 & 0.0000 & 1.0000 & 0.5900 & 1.0000 & 0.4920 & 0.0000 & 1.0000 \\
\hline SPONSORED & 0.0527 & 0.0000 & 0.2235 & 0.0000 & 1.0000 & 0.1000 & 0.0000 & 0.3010 & 0.0000 & 1.0000 \\
\hline RATING_CAT & 2.4850 & 3.0000 & 0.7384 & 1.0000 & 3.0000 & 2.8100 & 3.0000 & 0.4380 & 1.0000 & 3.0000 \\
\hline SYND & 8.5710 & 7.0000 & 7.4504 & 1.0000 & 76.0000 & 6.9200 & 5.0000 & 5.5200 & 1.0000 & $30.000 \mathrm{C}$ \\
\hline MATURITY & 33.0766 & 36.0000 & 20.4622 & 2.0000 & 95.0000 & 41.4000 & 43.0000 & 20.1090 & 6.0000 & $84.000 \mathrm{C}$ \\
\hline LOAN_SIZE & 19.0522 & 19.1138 & 1.2761 & 15.2018 & 22.4280 & 19.0913 & 18.9803 & 1.0640 & 16.5236 & 21.8219 \\
\hline COVEN & 0.6804 & 1.0000 & 0.4665 & 0.0000 & 1.0000 & 0.7200 & 1.0000 & 0.4500 & 0.0000 & 1.0000 \\
\hline
\end{tabular}


TABLE 8 (Concluded)

Descriptive Statistics

\begin{tabular}{|c|c|c|c|c|c|c|c|c|c|c|}
\hline & \multirow[t]{2}{*}{ Mean } & Med. & & Min. & \multirow[t]{3}{*}{ Max. } & \multirow[t]{3}{*}{ Mean } & Med. & Std. & Min. & \multirow[t]{3}{*}{ Max. } \\
\hline & & \multicolumn{3}{|c|}{ ICDs sample $N=398$} & & & \multicolumn{3}{|c|}{ Effective IC sample $=1404$} & \\
\hline \multicolumn{8}{|c|}{ Panel C: Loan-Specific Characteristics } & & & \\
\hline S_REVOLVERS & 0.1260 & 0.0000 & 0.3318 & 0.0000 & 1.0000 & 0.2913 & 0.0000 & 0.4545 & 0.0000 & 1.0000 \\
\hline L_REVOLVERS & 0.6130 & 1.0000 & 0.4877 & 0.0000 & 1.0000 & 0.5036 & 1.0000 & 0.5002 & 0.0000 & 1.0000 \\
\hline BANK_LENDERS & 0.0350 & 0.0000 & 0.1845 & 0.0000 & 1.0000 & 0.0178 & 0.0000 & 0.1323 & 0.0000 & 1.0000 \\
\hline INSTIT_LENDERS & 0.0900 & 0.0000 & 0.2872 & 0.0000 & 1.0000 & 0.0684 & 0.0000 & 0.2525 & 0.0000 & 1.0000 \\
\hline CAP & 0.0000 & 0.0000 & 0.0000 & 0.0000 & 0.0000 & 0.0150 & 0.0000 & 0.1214 & 0.0000 & 1.0000 \\
\hline CORP & 0.5100 & 1.0000 & 0.5010 & 0.0000 & 1.0000 & 0.3198 & 0.0000 & 0.4666 & 0.0000 & 1.0000 \\
\hline CP_PACKUP & 0.0600 & 0.0000 & 0.2380 & 0.0000 & 1.0000 & 0.1681 & 0.0000 & 0.3741 & 0.0000 & 1.0000 \\
\hline DEBT & 0.0600 & 0.0000 & 0.2380 & 0.0000 & 1.0000 & 0.0677 & 0.0000 & 0.2513 & 0.0000 & 1.0000 \\
\hline TAKEOVER & 0.0500 & 0.0000 & 0.2190 & 0.0000 & 1.0000 & 0.0406 & 0.0000 & 0.1974 & 0.0000 & 1.0000 \\
\hline OTHER_LOANS & 0.0200 & 0.0000 & 0.1220 & 0.0000 & 1.0000 & 0.0363 & 0.0000 & 0.1872 & 0.0000 & 1.0000 \\
\hline SECURED & 0.5900 & 1.0000 & 0.4920 & 0.0000 & 1.0000 & 0.3917 & 0.0000 & 0.4883 & 0.0000 & 1.0000 \\
\hline SPONSORED & 0.1000 & 0.0000 & 0.3010 & 0.0000 & 1.0000 & 0.0392 & 0.0000 & 0.1941 & 0.0000 & 1.0000 \\
\hline RATING_CAT & 2.8100 & 3.0000 & 0.4380 & 1.0000 & 3.0000 & 2.3917 & 3.0000 & 0.7786 & 1.0000 & 3.0000 \\
\hline SYND & 6.9200 & 5.0000 & 5.5200 & 1.0000 & 30.0000 & 9.0392 & 7.0000 & 7.8510 & 1.0000 & 76.0000 \\
\hline MATURITY & 41.4000 & 43.0000 & 20.1090 & 6.0000 & 84.0000 & 30.7179 & 30.0000 & 19.9462 & 2.0000 & 95.0000 \\
\hline LOAN_SIZE & 19.0913 & 18.9803 & 1.0640 & 16.5236 & 21.8219 & 19.0412 & 19.1138 & 1.3302 & 15.2018 & 22.4280 \\
\hline COVEN & 0.7200 & 1.0000 & 0.4500 & 0.0000 & 1.0000 & 0.6695 & 1.0000 & 0.4706 & 0.0000 & 1.0000 \\
\hline
\end{tabular}

IA= Natural log of the difference between the average annual bid and ask spread of the traded facility. ICDS= an indicator variable equals 1 if the firm disclosed Internal Control Deficiencies, zero otherwise. ICMWs= an indicator variable $=1$ if the firm disclosed ICMWs under section 302 or section 404, zero otherwise. ICMWs_302= an indicator variable $=1$ if the firm disclosed ICMWs under section 302, zero otherwise. ICMWs $4404=$ an indicator variable $=1$ if the firm disclosed ICMWs under section 404, zero otherwise. $\mathrm{CL}=$ an indicator variable equal 1 if the disclosed IC weaknesses is on the company level, zero otherwise. $\mathrm{REM}=$ an indicator variable $=1$ if the firm remediated part or all the disclosed IC weaknesses in the year t-1, zero otherwise. ROA= Return on Asset is Income before Extraordinary items / lagged total assets. ASSETS= Natural log of total assets [Compustat data item \# 6]. MTB= Natural $\log$ of the ratio of the firm's market value to book value of common equity, computed as [share price times the number of shares outstanding [Compustat data item \#25 * Compustat data item \#199] divided by [Compustat data item \# 60]. DA= I measure the discretionary accruals using the correct model of the Modified Jones Model as in Dechow, Sloan and Sweeney (2005). REG= an indicator variable $=1$ if the firm is in regulated industry such as financial or utility industry (SIC codes 6000-6999 and 4900-4999), zero otherwise. $\mathrm{LQ}=$ Natural log of the volume of stock traded. LOSS= an indicator variable $=1$ if the firm had losses over the last two years [Compustat data item \# 172]. AUD_D = an indicator variable $=1$ if the firm dismissed the auditor, zero otherwise. AUD_R $=$ an indicator variable $=1$ if the auditor resigned, zero otherwise. BIG_6= an indicator variable $=1$ if the financial statements are audited by one of the top 6 audit firms, zero otherwise. S_REVOLVERS= an indicator variable $=1$ if it is a short term revolver loan such as 364-Day Facility, and 0 otherwise. L_REVOLVERS= an indicator variable $=1$ if it is a long term revolver loan such as Revolver/Line $>=1 \mathrm{Yr}$., and 0 otherwise. BANK_LENDERS $=$ an indicator variable $=1$ if the identity of the lender is a bank (Term Loan A), and 0 otherwise. INSTIT_LENDERS $=$ An indicator variable $=1$ if the identity of the lender is an institutional lender (Term Loan B, C, and D), and 0 otherwise. CAP= an indicator variable $=1$ if the loan purpose is to cover capital expenditures, and 0 otherwise. $\mathrm{CORP}=$ an indicator variable $=1$ if the loan purpose is to cover corporate expenditures, and 0 otherwise. CP_BACKUP= an indicator variable $=1$ if the loan is a CP Back Up, and 0 otherwise. DEBT= an indicator variable $=1$ if the loan purpose is to repay debt, and 0 otherwise. TAKEOVER $=$ An indicator variable $=1$ if the loan purpose is takeover, and 0 otherwise. OTHER_LOANS= an indicator variable $=1$ if the loan purpose is any other reason than the ones listed above, and 0 otherwise. SECURED= An indicator variable $=1$ if it is a secured loan, and 0 otherwise. SPONSORED= an indicator variable $=1$ if it is a sponsored loan, and 0 otherwise. RATING_CAT= A continuous number indicating the rating categories. $\mathrm{SYND}=\mathrm{A}$ continuous number indicating number of lenders. MATURITY= A continuous number indicating the maturity of a loan or the length of time until the loan is due. LOAN_SIZE $=$ Natural $\log$ of the loan value in dollar amount. COVEN $=$ an indicator variable $=1$ if covenants exist, and 0 otherwise. SOX $404=$ an indicator variable $=1$ if the reporting period underlying SOX 404 period, zero otherwise. IND= Eight indicator variables to represent the different industries in my sample firms, SIC two digits code are used to categorize the industries. 
Table 9 summarizes the descriptive statistics by year for the variables of interest within only the ICDs sample of firms. Panels A, B, C and D of table 9 contains the four years of sample period from 2002-2005, respectively. Panel A shows that the average IA in 2001 are 147.5 and ranges from 50-300 with standard deviation of 93.6544. It also shows that $71.43 \%$ of ICDs sample in 2002 are firms with ICMWs, $28.57 \%$ (42.86\%) out of these firms are firms with ICMWs reported under section 302 (section 404). Within the same year, $85.71 \%$ of firms with reported weaknesses are having CL weaknesses and only $42.86 \%$ were able to remediate their Internal Control Deficiencies.

Panel B summarizes the descriptive statistics for the year 2003 and it indicates that IA goes up to reach 191.667 on average with standard deviation of 52.8594 and ranges from 100-250. $66.67 \%$ of the sample are firms with ICMWs of which $44.44 \%$ are firms with ICMWs reported under section 302, while $22.22 \%$ were reported under section $404.66 .67 \%$ are firms with CL and $55.56 \%$ of the reported weaknesses were remediated by the firm or auditor.

The average IA goes down in year 2004 relative to IA in year 2003 as shown in Panel C. Average IA in 2004 scored 176.0714 with standard deviation of 95.7838 and ranges from 19400. Panel C shows that ICMWs in 2004 are $93.65 \%$ of the ICDs sample, while $3.17 \%$ (90.48\%) are firms with ICMWs reported under section 302 (section 404). 26.98\% of firms in 2004 are with CL weaknesses and almost one third of the reported firms with ICMWs remediated their Internal Control Deficiencies. IA reported the highest average in 2005 (214.2208) as panel D suggests. The average IA in 2005 ranges from 18-650 with standard deviation 132.9292 and median of 187.5, the highest among all IA in all years. 
TABLE 9

Descriptive Statistics by Year

\begin{tabular}{|c|c|c|c|c|c|}
\hline & Mean & Median & Std. Deviation & Minimum & Maximum \\
\hline \multicolumn{6}{|c|}{ Panel A: For the year 2002} \\
\hline \multicolumn{6}{|l|}{$\mathrm{N}=14$} \\
\hline IA & 147.5000 & 150.0000 & 93.6544 & 50.0000 & 300.0000 \\
\hline ICMWs & 0.7143 & 1.0000 & 0.4688 & 0.0000 & 1.0000 \\
\hline ICMWs_302 & 0.2857 & 0.0000 & 0.4688 & 0.0000 & 1.0000 \\
\hline ICMWs_404 & 0.4286 & 0.0000 & 0.5136 & 0.0000 & 1.0000 \\
\hline CL & 0.8571 & 1.0000 & 0.3631 & 0.0000 & 1.0000 \\
\hline REM & 0.4286 & 0.0000 & 0.5136 & 0.0000 & 1.0000 \\
\hline \multicolumn{6}{|c|}{ Panel B: For the year 2003} \\
\hline \multicolumn{6}{|c|}{$\mathrm{N}=18$} \\
\hline IA & 191.6667 & 175.0000 & 52.8594 & 100.0000 & 250.0000 \\
\hline ICMWs & 0.6667 & 1.0000 & 0.4851 & 0.0000 & 1.0000 \\
\hline ICMWs_302 & 0.4444 & 0.0000 & 0.5113 & 0.0000 & 1.0000 \\
\hline ICMWs_404 & 0.2222 & 0.0000 & 0.4278 & 0.0000 & 1.0000 \\
\hline CL & 0.6667 & 1.0000 & 0.4851 & 0.0000 & 1.0000 \\
\hline REM & 0.5556 & 1.0000 & 0.5113 & 0.0000 & 1.0000 \\
\hline \multicolumn{6}{|c|}{ Panel C: For the year 2004} \\
\hline \multicolumn{6}{|l|}{$\mathrm{N}=126$} \\
\hline IA & 176.0714 & 180.0000 & 95.7838 & 19.0000 & 400.0000 \\
\hline ICMWs & 0.9365 & 1.0000 & 0.2448 & 0.0000 & 1.0000 \\
\hline ICMWs_302 & 0.0317 & 0.0000 & 0.1760 & 0.0000 & 1.0000 \\
\hline ICMWs_404 & 0.9048 & 1.0000 & 0.2947 & 0.0000 & 1.0000 \\
\hline CL & 0.2698 & 0.0000 & 0.4456 & 0.0000 & 1.0000 \\
\hline REM & 0.3333 & 0.0000 & 0.4733 & 0.0000 & 1.0000 \\
\hline \multicolumn{6}{|c|}{ Panel D: For the year 2005} \\
\hline \multicolumn{6}{|l|}{$\mathrm{N}=240$} \\
\hline IA & 214.2208 & 187.5000 & 132.9292 & 18.0000 & 650.0000 \\
\hline ICMWs & 0.9333 & 1.0000 & 0.2500 & 0.0000 & 1.0000 \\
\hline ICMWs_302 & 0.0000 & 0.0000 & 0.0000 & 0.0000 & 0.0000 \\
\hline ICMWs_404 & 0.9333 & 1.0000 & 0.2500 & 0.0000 & 1.0000 \\
\hline CL & 0.3083 & 0.0000 & 0.4628 & 0.0000 & 1.0000 \\
\hline REM & 0.1000 & 0.0000 & 0.3006 & 0.0000 & 1.0000 \\
\hline
\end{tabular}

$\mathrm{IA}=$ the difference between the average annual bid and ask spread of the traded facility. ICDS $=$ an indicator variable equals 1 if the firm disclosed Internal Control Deficiencies, zero otherwise. ICMWs $=$ an indicator variable $=1$ if the firm disclosed ICMWs under section 302 or section 404, zero otherwise. ICMWs $302=$ an indicator variable $=1$ if the firm disclosed ICMWs under section 302, zero otherwise.

ICMWs_404 $=$ an indicator variable $=1$ if the firm disclosed ICMWs under section 404, zero otherwise. $C L=$ an indicator variable equal 1 if the disclosed IC weaknesses on the company level, zero otherwise. REM $=$ an indicator variable $=1$ if the firm remediated part or all the disclosed IC weaknesses in the year $\mathrm{t}-1$, zero otherwise. 
The correlation matrix is in table 10. Table 10 consists of four panels. Panel A summarizes the correlations among IA and ICD variables. Panel B summarizes the correlations among IA, ICD variables, and firm-specific characteristics. Panel C summarizes the correlations among IA and ICD variables, firm and loan-specific characteristics. Panel D shows the correlations among loan-specific characteristics. As predicted, panel A shows a statistically significant positive correlation at $1 \%$ and p-value $<0.01$ between IA and ICD variables such as ICMWs, ICMW_404, ICD, and CL. It also shows a strong statistically-significant positive correlation at $1 \%$ and p-value $<0.01$ among ICD variables such as between ICMWs_404 and ICMWs and between ICD and ICMWs, suggesting a probable multicollinearity among the ICDs measures. This multicollinearity would be an obstacle to run a model with an interaction term between measures of ICDs.

Panel B shows a significant negative correlation between IA and ROA, Assets, MTB, Liquidity at $1 \%$ and p-value $<0.01$ and Big 6 audit firms at $5 \%$ and p-value $<0.05$. It also shows a significant positive correlation between IA and losses and audit resignation and dismissal (auditor changes). The previous correlations in panel B suggest that firms with good firm performance as measured by ROA, big firms as measured by total assets, firms with higher liquidity, and firms that involve Big 6 in the audit process are associated with lower IA. Similarly, firms with losses and that experience auditor changes are associated with higher IA. Panel B documents a significant positive correlation between Liquidity and assets, ICMW_404 and post-section 302 period, ICDs and post-section 302 period, indicating a possible multicollinearity among these variables.

Panel $\mathrm{C}$ indicates a positive significant correlation between IA and long-term revolvers, bank lenders, institutional lenders, capital-expenditure loans, corporate-purpose loans, debt 
loans, takeover loans, secured loans, sponsored loans, loans with a low credit rating, maturity and the existence of debt covenants. There is a negative significant correlation between IA and CP backup loans, the number of lenders (syndication), and loan size.

Panel $\mathrm{C}$ also shows high significant positive correlation between loan size and assets as well as loan size and liquidity. Panel D summarizes the correlation among the loan-specific characteristics and it shows a negative significant correlation between long and short revolvers. It also shows positive significant correlation between $\mathrm{CP}$ backup and short term revolvers. A significant negative correlation exists between short term revolvers and credit rating, maturity and covenants. A positive significant correlation exists between credit rating and secured loans as well as loan size and syndication or the number of lenders. Overall, other correlations are nonsignificant and modest $(<0.5)$, indicating the absence of the multicollienarity among most of the loan-specific characteristics. 
TABLE 10

Spearman Correlations Matrixes

Panel A: Correlations among IA and ICD Variables

\begin{tabular}{llllllll}
\hline & IA & ICMWs & ICMWs_302 & ICMWs_404 & ICD & CL & REM \\
\cline { 2 - 8 } IA & 1.0000 & $\mathbf{0 . 1 3 1 7} * * *$ & -0.0034 & $\mathbf{0 . 1 3 4 8} * * *$ & $\mathbf{0 . 1 5 5 8} * * *$ & $\mathbf{0 . 0 6 8 3} * * *$ & $\mathbf{0 . 0 6 6 9} * * *$ \\
ICMWs & & 1.0000 & $0.1881 * * *$ & $\mathbf{0 . 9 7 2 4} * * *$ & $\mathbf{0 . 9 4 5 0} * * *$ & $0.4845 * * *$ & $0.4075 * * *$ \\
ICMWs_302 & & 1.0000 & $-0.0463 * *$ & $0.1778 * * *$ & $0.2913 * * *$ & $0.2632 * * *$ \\
ICMWs_404 & & & 1.0000 & $\mathbf{0 . 9 1 8 9} * * *$ & $0.4236 * * *$ & $0.3519 * * *$ \\
ICD & & & 1.0000 & $\mathbf{0 . 5 2 8 0} * * *$ & $0.4101 * * *$ \\
CL & & & & & 1.0000 & $0.0613 * * *$ \\
REM & & & & & & 1.0000
\end{tabular}

***. Correlation is significant at the 0.01 level (2-tailed). **. Correlation is significant at the 0.05 level (2-tailed), *. Correlation is significant at the 0.10 level (2-tailed.) Using a cut-off of .5, all significant correlations equal to or greater than .5 are in bold. Also, correlation among variables of interest such as IA and IC measures is in bold. 
TABLE 10 (Concluded)

Panel B: Correlation among IA, ICD Variables, and Firm-Specific Characteristics

\begin{tabular}{|c|c|c|c|c|c|c|c|c|c|c|c|}
\hline & ROA & ASSETS & MTB & DA & REG & LQ & LOSS & AUD_D & AUD_R & BIG_6 & SOX 404 \\
\hline IA & $-0.3290 * * *$ & $-0.5396 * * *$ & $-0.1355 * * *$ & 0.0248 & $-0.1711 * * *$ & $-0.4730 * * *$ & $0.2889 * * *$ & $0.0490 * *$ & $0.0744 * * *$ & $-0.0553 * *$ & $0.1527 * * *$ \\
\hline ICMWs & $-0.2547 * * *$ & $-0.0897 * * *$ & $0.1237 * * *$ & $-0.0599 * *$ & $-0.1327 * * *$ & $-0.1030 * * *$ & $0.1386^{* * *}$ & $-0.0932 * * *$ & $0.1767 * * *$ & $-0.1014 * * *$ & $0.9210 * * *$ \\
\hline ICMWs_302 & -0.0363 & $0.0565 * *$ & 0.0292 & $0.0645 * * *$ & -0.0032 & $0.0396 *$ & $0.0837 * * *$ & -0.0339 & -0.0112 & 0.0115 & 0.0110 \\
\hline ICMWs_404 & $-0.2504 * * *$ & $-0.1047 * * *$ & $0.1188 * * *$ & $-0.0762 * * *$ & $-0.1342 * * *$ & $-0.1141 * * *$ & $0.1211 * * *$ & $-0.0867 * * *$ & $0.1824 * * *$ & $-0.1059 * * *$ & $0.9341 * * *$ \\
\hline ICD & $-0.2490 * * *$ & $-0.1099 * * *$ & $0.1296 * * *$ & $-0.0436^{*}$ & $-0.1436 * * *$ & $-0.1294 * * *$ & $0.1421 * * *$ & $-0.0981 * * *$ & $0.1656^{* * *}$ & $-0.0926 * * *$ & $0.9482 * * *$ \\
\hline CL & $-0.1591 * * *$ & 0.0216 & $0.0831 * * *$ & -0.0268 & -0.0239 & 0.0192 & $0.1285^{* * *}$ & $-0.0739 * * *$ & 0.0031 & -0.0017 & $0.4298 * * *$ \\
\hline REM & $-0.1447 * * *$ & $-0.0835 * * *$ & $0.0886^{* * *}$ & -0.0086 & $-0.0707 * * *$ & $-0.0438^{*}$ & $0.1073^{* * * *}$ & -0.0279 & $0.2018 * * *$ & $-0.1076 * * *$ & $0.3266^{* * * *}$ \\
\hline ROA & 1.0000 & 0.0001 & $0.3062 * * *$ & $0.0550 * *$ & -0.0145 & $0.0435^{*}$ & $-0.4993 * * *$ & $-0.0392 *$ & -0.0267 & -0.0060 & $-0.2479 * * *$ \\
\hline ASSETS & & 1.0000 & $-0.0916^{* * *}$ & -0.0209 & $0.2914 * * *$ & $0.7515 * * *$ & $-0.0624 * * *$ & $-0.0718 * * *$ & $-0.0498 * *$ & $0.1320 * * *$ & $-0.1174 * * *$ \\
\hline МТВ & & & 1.0000 & $-0.0442 *$ & $-0.2751 * * *$ & $0.1512 * * *$ & $-0.1256 * * *$ & -0.0187 & $0.0830 * * *$ & 0.0201 & $0.1252 * * *$ \\
\hline DA & & & & 1.0000 & -0.0176 & $-0.0620 * * *$ & -0.0108 & -0.0234 & $0.0396^{*}$ & -0.0013 & $-0.0484^{* *}$ \\
\hline REG & & & & & 1.0000 & 0.0210 & -0.0244 & 0.0069 & $-0.0389 *$ & $0.0726 * * *$ & $-0.1403 * * *$ \\
\hline LQ & & & & & & 1.0000 & -0.0240 & $-0.0526^{* *}$ & -0.0347 & $0.1347 * * *$ & $-0.1275^{* * *}$ \\
\hline LOSS & & & & & & & 1.0000 & 0.0281 & -0.0002 & $0.0618 * * *$ & $0.1186^{* * *}$ \\
\hline AUD_R & & & & & & & & 1.0000 & $-0.0425^{*}$ & $0.0434 *$ & $-0.1027 * * *$ \\
\hline AUD_D & & & & & & & & & 1.0000 & $-0.0652 * * *$ & $0.1760 * * *$ \\
\hline BIG_6 & & & & & & & & & & 1.0000 & $-0.1009^{* * *}$ \\
\hline SOX 404 & & & & & & & & & & & 1.0000 \\
\hline
\end{tabular}

***. Correlation is significant at the 0.01 level (2-tailed). **. Correlation is significant at the 0.05 level (2-tailed), *. Correlation is significant at the 0.10 level (2-tailed.) Using a cut-off of .5, all significant correlations equal to or greater than .5 are in bold. 


\section{TABLE 10 (Concluded)}

Panel C: Correlation among IA, ICD Variables, Firm and Loan-Specific Characteristics

\begin{tabular}{|c|c|c|c|c|c|c|c|c|}
\hline & S_REVOLVERS & L_REVOLVERS & BANK_LENDERS & INSTIT_LENDERS & CAP & CORP & CP_PACKUP & DEBT \\
\hline IA & $-0.5278 * * *$ & $0.1672 * * *$ & $0.1444 * * *$ & $0.2848 * * *$ & $0.0650 * * *$ & $0.0608 * * *$ & $-0.4910 * * *$ & $0.1548 * * *$ \\
\hline ICMWs & $-0.1419 * * *$ & $0.0717 * * *$ & $0.0582 * *$ & 0.0283 & $-0.0546 * *$ & $0.1511 * * *$ & $-0.1122 * * *$ & -0.0113 \\
\hline ICMWs_302 & $0.0804 * * *$ & $-0.0764 * * *$ & -0.0141 & 0.0188 & -0.0103 & -0.0219 & $0.0621 * * *$ & -0.0252 \\
\hline ICMWs_404 & $-0.1634 * * *$ & $0.0911 * * *$ & $0.0625 * * *$ & 0.0243 & $-0.0531 * *$ & $0.1589 * * *$ & $-0.1289 * * *$ & -0.0056 \\
\hline ICD & $-0.1577 * * *$ & $0.0910 * * *$ & $0.0495 * *$ & 0.0351 & $-0.0578 * *$ & $0.1621 * * *$ & $-0.1273 * * *$ & -0.0123 \\
\hline CL & $-0.0470 * *$ & -0.0156 & -0.0125 & 0.0354 & -0.0305 & $0.0546^{* *}$ & $-0.0427 *$ & 0.0110 \\
\hline REM & -0.0299 & $0.0572 * *$ & -0.0325 & $-0.0409 *$ & -0.0237 & $0.0575^{* *}$ & 0.0013 & $-0.0581 * *$ \\
\hline ROA & $0.1008 * * *$ & -0.0245 & $0.0448 *$ & $-0.0725 * * *$ & $-0.0883 * * *$ & $-0.1310 * * *$ & $0.1444 * * *$ & -0.0091 \\
\hline ASSETS & $0.4449 * * *$ & $-0.3347 * * *$ & -0.0210 & -0.0361 & $-0.1078 * * *$ & -0.0255 & $0.4491 * * *$ & $-0.0952 * * *$ \\
\hline MTB & $0.1169 * * *$ & $-0.1158 * * *$ & $0.0418 *$ & $-0.0538 * *$ & 0.0113 & $-0.0548 * *$ & $0.1501 * * *$ & $-0.0579 * *$ \\
\hline DA & $-0.0448 *$ & 0.0087 & $-0.0719 * * *$ & -0.0018 & $-0.0400 *$ & 0.0189 & $-0.0836 * * *$ & -0.0089 \\
\hline REG & $0.1025 * * *$ & $-0.0724 * * *$ & $-0.0547 * *$ & $-0.0625 * * *$ & 0.0286 & -0.0113 & $0.0651 * * *$ & $-0.0886 * * *$ \\
\hline LQ & $0.4067 * * *$ & $-0.3010 * * *$ & -0.0270 & $-0.0557 * *$ & $-0.0794 * * *$ & -0.0057 & $0.4054 * * *$ & $-0.0903 * * *$ \\
\hline LOSS & $-0.2067 * * *$ & $0.0861 * * *$ & $-0.0452 *$ & $0.1414 * * *$ & $0.0752 * * *$ & $0.0390 *$ & $-0.1364 * * *$ & $0.0506 * *$ \\
\hline AUD_D & 0.0352 & -0.0042 & $-0.0413 *$ & $0.0468 * *$ & -0.0226 & -0.0111 & -0.0228 & 0.0384 \\
\hline AUD_R & $-0.0585 * *$ & 0.0077 & -0.0176 & -0.0333 & -0.0129 & $0.0491 * *$ & -0.0352 & 0.0067 \\
\hline BIG_6 & 0.0280 & $0.0720 * * *$ & 0.0180 & -0.0017 & 0.0131 & -0.0253 & $0.0497 * *$ & 0.0322 \\
\hline SOX 404 & $-0.1812 * * *$ & $0.1073 * * *$ & $0.0576^{* *}$ & 0.0381 & $-0.0548 * *$ & $0.1831 * * *$ & $-0.1445 * * *$ & -0.0121 \\
\hline
\end{tabular}

***. Correlation is significant at the 0.01 level (2-tailed). **. Correlation is significant at the 0.05 level (2-tailed), $*$. Correlation is significant at the 0.10 level (2-tailed.) Using a cut-off of .5, all significant correlations equal to or greater than .5 are in bold. Also, correlation among the variables of interest is also in bold. 


\section{TABLE 10 (Concluded)}

Panel C (concluded): Correlation among IA, ICD Variables, Firm and Loan-Specific Characteristics

\begin{tabular}{|c|c|c|c|c|c|c|c|c|c|}
\hline & TAKEOVER & $\begin{array}{c}\text { OTHER_ } \\
\text { LOANS }\end{array}$ & SECURED & SPONSORED & $\begin{array}{c}\text { RATING_ } \\
\text { CAT }\end{array}$ & SYND & MATURITY & $\begin{array}{c}\text { LOAN_ }_{-} \\
\text {SIZE }\end{array}$ & COVEN \\
\hline IA & $0.0774 * * *$ & 0.0180 & $0.5975 * * *$ & $0.2122 * * *$ & $0.6667 * * *$ & $-0.4064 * * *$ & $0.4287 * * *$ & $-0.3320 * * *$ & $0.2487 * * *$ \\
\hline ICMWs & 0.0304 & $-0.0435^{*}$ & $0.1539 * * *$ & $0.1163 * * *$ & $0.2227 * * *$ & $-0.0930 * * *$ & $0.2005 * * *$ & 0.0194 & $0.0425^{*}$ \\
\hline ICMWs_302 & 0.0385 & $0.0505^{* *}$ & 0.0122 & -0.0223 & -0.0113 & 0.0203 & -0.0373 & $0.0520 * *$ & $0.0649 * * *$ \\
\hline ICMWs_404 & 0.0218 & $-0.0563 * *$ & $0.1537 * * *$ & $0.1236 * * *$ & $0.2292 * * *$ & $-0.0994 * * *$ & $0.2128 * * *$ & 0.0074 & 0.0278 \\
\hline ICD & 0.0198 & $-0.0504 * *$ & $0.1683 * * *$ & $0.1138 * * *$ & $0.2355 * * *$ & $-0.1067 * * *$ & $0.2300 * * *$ & 0.0045 & $0.0437 *$ \\
\hline $\mathbf{C L}$ & $0.0880 * * *$ & -0.0265 & 0.0362 & $0.0480^{* *}$ & $0.0924 * * *$ & -0.0190 & $0.1156^{* * *}$ & $0.0575^{* *}$ & $0.0557 * *$ \\
\hline REM & -0.0198 & -0.0090 & $0.0979 * * *$ & $-0.0515 * *$ & $0.0665 * * *$ & $-0.0608 * * *$ & $-0.0401 *$ & -0.0384 & $0.0811 * * *$ \\
\hline ROA & $-0.0705 * * *$ & $0.0661 * * *$ & $-0.2457 * * *$ & $-0.0504 * *$ & $-0.1733 * * *$ & $0.1625^{* * *}$ & $-0.0463^{* *}$ & $0.0504 * *$ & 0.0003 \\
\hline ASSETS & 0.0082 & $0.0394 *$ & $-0.4086 * * *$ & -0.0165 & $-0.6789 * * *$ & $0.5723 * * *$ & $-0.2366 * * *$ & $0.6830 * * *$ & $-0.2867 * * *$ \\
\hline MTB & $0.0635 * * *$ & 0.0324 & $-0.0604 * *$ & -0.0018 & $-0.0519 * *$ & $0.0713 * * *$ & $-0.0434 *$ & $0.0398 *$ & -0.0154 \\
\hline DA & $-0.1117 * * *$ & $0.0976 * * *$ & 0.0382 & $-0.0506^{* *}$ & $0.0682 * * *$ & $-0.0467 * *$ & 0.0060 & $-0.0648 * * *$ & $0.0538 * *$ \\
\hline REG & $-0.0521 * *$ & $0.0425^{*}$ & $-0.2563 * * *$ & $-0.1078 * * *$ & $-0.3052 * * *$ & $0.0551 * *$ & $-0.1759 * * *$ & $0.0430 *$ & $-0.1012 * * *$ \\
\hline LQ & 0.0239 & 0.0252 & $-0.3143 * * *$ & -0.0114 & $-0.5276 * * *$ & $0.4540 * * *$ & $-0.2569 * * *$ & $0.5398 * * *$ & $-0.2421 * * *$ \\
\hline LOSS & 0.0044 & -0.0126 & $0.2052 * * *$ & $0.0586^{* *}$ & $0.2053 * * *$ & $-0.1348 * * *$ & $0.1265 * * *$ & $-0.0444^{*}$ & $0.0771 * * *$ \\
\hline AUD_D & 0.0366 & -0.0248 & $0.0514 * *$ & -0.0063 & 0.0349 & -0.0178 & $-0.0547 * *$ & -0.0383 & $0.0507 * *$ \\
\hline AUD_R & -0.0251 & -0.0214 & 0.0105 & $0.0569 * *$ & $0.0800 * * *$ & $-0.0565 * *$ & 0.0262 & $-0.0549 * *$ & 0.0101 \\
\hline BIG_6 & -0.0205 & 0.0219 & $-0.0437 *$ & 0.0285 & $-0.0899 * * *$ & $0.1076 * * *$ & -0.0150 & $0.0730 * * *$ & $-0.0430 *$ \\
\hline SOX 404 & 0.0025 & $-0.0440^{*}$ & $0.1623 * * *$ & $0.1278 * * *$ & $0.2338 * * *$ & $-0.1067 * * *$ & $0.2445 * * *$ & -0.0003 & 0.0207 \\
\hline
\end{tabular}

significant correlations equal to or greater than .5 are in bold. Also, correlation among the variables of interest is also in bold. 
TABLE 10 (Concluded)

Panel D: Correlation among Loan-Specific Characteristics

\begin{tabular}{|c|c|c|c|c|c|c|c|c|}
\hline & S_REVOLVERS & L_REVOLVERS & BANK_LENDERS & INSTIT_LENDERS & CAP & CORP & CP_PACKUP & DEBT \\
\hline S_REVOLVERS & 1.0000 & $-0.6180^{* * * *}$ & $-0.0870^{* * * *}$ & $-0.1644 * * *$ & $-0.0397 *$ & $-0.0552 * *$ & $0.5465 * * *$ & $-0.1042 * * *$ \\
\hline L_REVOLVERS & & & $-0.1572 * * *$ & $-0.2972 * * *$ & -0.0319 & $0.0889 * * *$ & $-0.3044 * * *$ & 0.0233 \\
\hline BANK_LENDERS & & & & $-0.0418^{*}$ & -0.0162 & $-0.0483^{* * *}$ & $-0.0611^{* * *}$ & 0.0219 \\
\hline INSTIT_LENDERS & & & & & 0.0092 & $-0.0696 * * *$ & $-0.1154 * * *$ & $0.1568 * * *$ \\
\hline CAP & & & & & & $-0.0817 * * *$ & $-0.0446 *$ & -0.0289 \\
\hline CORP & & & & & & & $-0.3088^{* * *}$ & $-0.2000 * * *$ \\
\hline CP_PACKUP & & & & & & & & $-0.1092 * * *$ \\
\hline
\end{tabular}

***. Correlation is significant at the 0.01 level (2-tailed). **. Correlation is significant at the 0.05 level (2-tailed), *. Correlation is significant at the 0.10 level (2-tailed.) Using a cut-off of .5, all significant correlations equal to or greater than .5 are in bold. Also, correlation among the variables of interest is also in bold. 


\section{TABLE 10 (Concluded)}

Panel D (concluded): Correlation among Loan-Specific Characteristics

\begin{tabular}{|c|c|c|c|c|c|c|c|c|c|}
\hline & TAKEOVER & OTHER_LOANS & SECURED & SPONSORED & RATING_CAT & SYND & MATURITY & LOAN_SIZE & COVEN \\
\hline S_REVOLVERS & $-0.0731 * * *$ & $-0.0474 * *$ & $-0.3884 * * *$ & $-0.1379 * * *$ & $-0.5559 * * *$ & $0.3140 * * *$ & $-0.6176 * * *$ & $0.2865 * * *$ & $-0.1892 * * *$ \\
\hline L_REVOLVERS & $-0.0585^{* *}$ & $-0.1085 * * *$ & $0.2066^{* * *}$ & -0.0156 & $0.3164 * * *$ & $-0.1635 * * *$ & $0.2802 * * *$ & $-0.2364 * * *$ & $0.1859 * * *$ \\
\hline BANK_LENDERS & $0.1383 * * *$ & $0.0603 * *$ & $0.1537 * * *$ & $0.1014 * * *$ & $0.0842 * * *$ & 0.0283 & $0.1307 * * *$ & $0.1064 * * *$ & $0.0529 * *$ \\
\hline INSTIT_LENDERS & 0.0038 & $0.0465 * *$ & $0.1951 * * *$ & $0.2673 * * *$ & $0.1691 * * *$ & -0.0255 & $0.2990 * * *$ & $0.0889 * * *$ & $0.0603 * *$ \\
\hline CAP & -0.0229 & -0.0196 & $0.0400 *$ & -0.0256 & $0.0629 * * *$ & $-0.1014 * * *$ & -0.0279 & $-0.1180 * * *$ & 0.0301 \\
\hline CORP & $-0.1589 * * *$ & $-0.1359 * * *$ & -0.0139 & $0.0449^{*}$ & $0.0936 * * *$ & $-0.1377 * * *$ & 0.0122 & $-0.1062 * * *$ & $-0.1311 * * *$ \\
\hline CP_PACKUP & $-0.0868 * * *$ & $-0.0742 * * *$ & $-0.3357 * * *$ & $-0.0969 * * *$ & $-0.5771 * * *$ & $0.3983 * * *$ & $-0.3988 * * *$ & $0.3722 * * *$ & $-0.2130 * * *$ \\
\hline DEBT & $-0.0562 * *$ & $-0.0481 * *$ & $0.1266^{* * *}$ & $0.0773 * * *$ & $0.1172 * * *$ & -0.0125 & $0.1847 * * *$ & $0.0485^{* *}$ & 0.0385 \\
\hline TAKEOVER & & -0.0382 & $0.0521 * *$ & $0.0852 * * *$ & $0.1192 * * *$ & 0.0296 & $0.0886^{* * *}$ & $0.1338 * * *$ & $0.0566 * *$ \\
\hline OTHER_LOANS & & & -0.0311 & $-0.0426^{*}$ & $0.0796 * * *$ & $-0.0465 * *$ & $0.0493 * *$ & $-0.0755 * * *$ & $-0.1413 * * *$ \\
\hline SECURED & & & & $0.1280 * * *$ & $0.5004 * * *$ & $-0.2390 * * *$ & $0.3581 * * *$ & $-0.1840 * * *$ & $0.3965 * * *$ \\
\hline SPONSORED & & & & & $0.1496 * * *$ & 0.0044 & $0.2453 * * *$ & $0.1667 * * *$ & 0.0126 \\
\hline RATING_CAT & & & & & & $-0.4777 * * *$ & $0.4174 * * *$ & $-0.4443 * * *$ & $0.2608 * * *$ \\
\hline SYND & & & & & & & $-0.0573 * *$ & $0.7589 * * *$ & -0.0045 \\
\hline MATURITY & & & & & & & & 0.0040 & $0.1527 * * *$ \\
\hline LOAN_SIZE & & & & & & & & & $-0.0892 * * *$ \\
\hline COVEN & & & & & & & & & 1.0000 \\
\hline
\end{tabular}

***. Correlation is significant at the 0.01 level (2-tailed). **. Correlation is significant at the 0.05 level (2-tailed), *. Correlation is significant at the 0.10 level (2-tailed.) Using a cut-off of .5, all significant correlations equal to or greater than .5 are in bold. Also, correlation among the variables of interest is also in bold. 


\subsection{Univariate Analysis}

Table 11 summarizes the results of the univariate analysis. I used the full sample to test the statistical differences in the means and medians of the IA between the treatment and control samples. Table 11 is composed of five panels. Panel A summarizes the results of the differences in means and medians of IA across firms with effective versus ICD firms. Results of panel A support the first hypothesis $(\mathrm{Hla})$ that firms with ICDs are having significantly higher IA than firms with effective IC; and the p-value is $<0.01$ (significant at $1 \%$ ). Wilcoxon-test shows also a statistical significant difference between the distribution of IA for ICDs firms and IA of effective IC sample, with the ICDs having a higher median.

Panel B summarizes the differences of IA across two samples of firms, firms with ICMWs reported under section 302 versus ICMWs reported under section 404. Panel C indicates that there are significant differences between IA for firms with ICDs and ICMWs and firms without ICDs. Firms with ICDs and ICMWs are having significantly higher mean IA than firms without ICDs. Firms with more severe types of ICDs such as CL-ICDs have non-significant differences in the mean and median IA. There is no evidence that firms that took actions to correct their ICDs experience lower information asymmetry as panel E summarizes nonsignificant $\mathrm{t}$ and $\mathrm{z}$ values. 
TABLE 11

Univariate Analysis

Panel A: Effective IC versus ICD samples:

Difference Tests

\begin{tabular}{|c|c|c|c|c|c|c|}
\hline & Effe & ve IC & & & t-test & Wilcoxon-test \\
\hline & Mean & Median & Mean & Median & (p-value) & (z-value) \\
\hline IA & 153.419 & 154 & 175.907 & 154 & $-5.489 * * *$ & $5.532 * * *$ \\
\hline & 140 & & 3 & & & \\
\hline
\end{tabular}

Panel B: ICMW 302 versus ICMW 404 samples:

\begin{tabular}{|c|c|c|c|c|c|c|}
\hline & & & & & \multicolumn{2}{|c|}{ Difference Tests } \\
\hline & \multicolumn{2}{|c|}{ ICMWs_302 } & \multicolumn{2}{|c|}{ ICMWs_404 } & \multirow{2}{*}{$\begin{array}{l}\text { t-test } \\
\text { (p-value) }\end{array}$} & \multirow{2}{*}{$\begin{array}{c}\text { Wilcoxon-tes } \\
\text { (z-value) }\end{array}$} \\
\hline & Mean & Median & Mean & Median & & \\
\hline IA & 148.438 & 150 & 196.647 & 154 & 1.606 & 1.520 \\
\hline $\mathrm{N}$ & \multicolumn{2}{|c|}{16} & 348 & & & \\
\hline
\end{tabular}

Panel C: ICD*ICMW versus No ICD*ICMW

Difference Tests

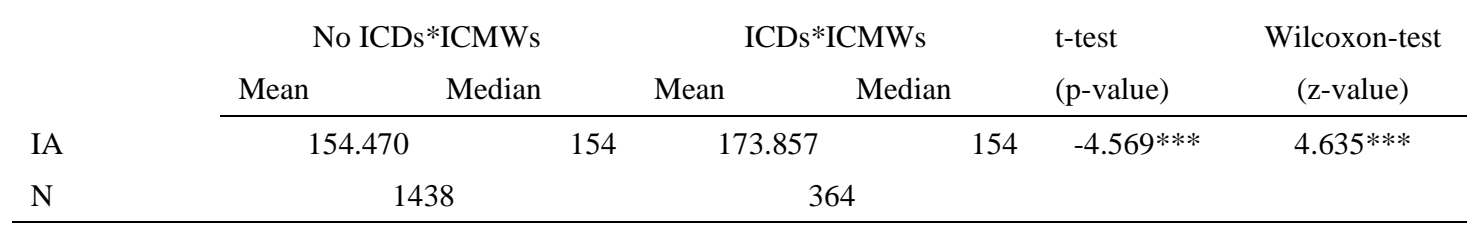

Panel D: ICD*CL versus No ICD*CL

Difference Tests

\begin{tabular}{|c|c|c|c|c|c|c|}
\hline & \multicolumn{2}{|c|}{ No ICDs*CL } & \multicolumn{2}{|c|}{$\mathrm{ICDs} * \mathrm{CL}$} & \multirow{2}{*}{$\begin{array}{l}\text { t-test } \\
\text { (p-value) }\end{array}$} & \multirow{2}{*}{$\begin{array}{c}\text { Wilcoxon-test } \\
\text { (z-value) }\end{array}$} \\
\hline & Mean & Median & Mean & Median & & \\
\hline IA & 158.191 & 150 & 160.856 & 175 & -.405 & .491 \\
\hline $\mathrm{N}$ & \multicolumn{2}{|c|}{1670} & \multicolumn{2}{|c|}{132} & & \\
\hline
\end{tabular}

Panel E: No REM versus REM

Difference Tests

\begin{tabular}{|c|c|c|c|c|c|c|}
\hline & \multicolumn{2}{|c|}{ No REM } & \multicolumn{2}{|c|}{ REM } & \multirow{2}{*}{$\begin{array}{l}\text { t-test } \\
\text { (p-value) }\end{array}$} & \multirow{2}{*}{$\begin{array}{l}\text { Wilcoxon-test } \\
\text { (z-value) }\end{array}$} \\
\hline & Mean & Median & Mean & Median & & \\
\hline IA & 202.408 & 154 & 184.78 & 154 & 1.189 & $2.577 * *$ \\
\hline $\mathrm{N}$ & \multicolumn{2}{|c|}{316} & \multicolumn{2}{|c|}{82} & & \\
\hline
\end{tabular}

\footnotetext{
The bid-ask spread is winzorized at $10 \%$ and $90 \%$

***. The difference is significant at the 0.01 level (2-tailed). **. The difference is significant at the 0.05 level (2-tailed). *. The difference is significant at the 0.10 level (2-tailed). ICDs*ICMWs $=$ the interaction term between the quality of internal control and the Internal Control Material Weaknesses (ICMW). ICDs*CL= the interaction term between Internal Control Deficiencies (ICDs) and Company Level (CL) internal control. In categorizing the Internal Control Deficiencies as either Company Level (CL) or Account-Specific (AS), I classified weaknesses in internal control related to any accounts such as: inventory, accounts receivables, loan receivables, gain or loss recognition issues, liabilities, reserves, Tax expense, Depreciation, depletion or amortization issues, and financial derivatives as Account- Specific (AS) weaknesses in internal control. With the same token, I classified weaknesses in internal control related to company level issues such as: Acquisition, merger, disposal or reorganization issues Deferred, stock-based or executive compensation issues, Intercompany issues, Foreign, related party, Consolidation, affiliated and/or subsidies issues as Company-Level (CL) weaknesses in internal control. I then manually coded firms with CL with 1 and firms with AS with zero. REM $=$ An indicator variable $=1$ if the firm remediated part or all the disclosed IC weaknesses in the year t1, zero otherwise. I manually coded firms that remediated part or all weaknesses in internal control with 1 and firms that did not remediate Internal Control Deficiencies with zero. For purposes of coding, I discarded the year 2002 from my manual coding since there is no need to measure the change from year 2001 to 2002. The remediation coding is done for only three paired years: 2002 versus 2003,2003 versus 2004 and 2004 versus 2005 .
} 


\subsection{Results of Hypotheses}

Tables 12-19 summarize the results of the multivariate analysis regression models that test the association between the disclosure of ICDs and its decomposition, types, and remediation and IA in the secondary loan market.

\subsubsection{H1a: The Effect of ICDs Disclosure on Information Asymmetry}

Table 12 summarizes the results on the regression of IA on the disclosure of ICDs in the secondary loan market for 533 (1802) firms (facilitates) from 2002-2005. It shows a strong statistically significant positive association between the disclosure of ICDs and IA with a positive slope of .194 . The model is statistically significant at $1 \%$ with p-vale $<0.01$. The model explains $65.3 \%$ of the variations in the IA as measured by Adjusted $\mathrm{R}^{2}$. I used the full sample (1802) to test model 1 and included in the regression a large pool of control variables to control for firm and loan-specific characteristics.

The results show also that IA has a negative significant association with ROA, Assets, MTB, Liquidity, and loan size. This latter result supports the notion that big firms, high performers of firms, well established, large loans and profitable firms are experiencing lower IA than other small firms, low performers of firms. These results make sense, especially in the secondary loan market where big firms are able to reduce their overall information asymmetry, and it also implies that IA are not uniform across different firm sizes.

These latter results may be explained by the argument that big firms are more likely to have larger resources and be able to invest in their internal control systems, disclose interim reports and hence enhance transparency and disclosure of information. They also have top tier audit firms endorse their financial reporting. IA are having a statistically positive association 
with loss firms, revolvers loan, CP pack-up loans, credit rating category and loan maturity. These latter positive associations imply an increase in the magnitude of IA in the presence of loss firms, long time to maturity and lower credit rating as well as certain types of loans such as revolvers and CP pack-up loans. Overall, the results of table 12 supports H1a that in the secondary loan market, the disclosure of Internal Control Deficiencies is positively associated with information asymmetry post SOX 2002. This result might be explained by the fact that disclosure of Internal Control Deficiencies increases the level of risk traders are willing to assume and hence increases the information asymmetry in the market.

Results on table 12 can also be explained by Beneish, Billings and Hodder (2008) who claim that when a weakness in the internal control system is disclosed to the public, it increases the uncertainty about the firm's internal operations and activities since the disclosure of ICDs is symptomatic of increased business risk (Ogneva, Subramanyam, and Raghunandan, 2007.) Additionally, uncertainty increases the demand for risk-taking actions by investors and traders. Hence, informed traders in the secondary loan market will demand more private information about unsecured collateral and increase the cost of borrowing to the firm relative to that cost demanded by informed traders. Disclosure of ineffective ICs affects past, present and future financial reporting (Irving, 2006) providing information to internal managers and market-wide participants for decision-making purposes such as buying and selling decisions, ratings by credit agencies, loan decisions, and rating firm creditworthiness.

Additionally, the results in this section suggest that the quality of accounting information matters in the secondary loan market. In other words, an effective IC system might play the same role that other proxies of the quality of accounting information do, such as the role of timely loss recognition in the secondary loan market (Moerman, 2008.) Moerman (2008) also finds that 
timely loss recognition reduces information asymmetry in the secondary loan market. In other words, Moerman (2008) suggests that timely loss recognition increases debt contracting efficiency and reduces the agency cost through underestimating the net asset value and hence facilitates the monitoring by debt holders. 
TABLE 12

Regression of Information Asymmetry on Internal Control Deficiencies post SOX 2002

\begin{tabular}{|c|c|c|c|}
\hline \multirow{2}{*}{$\begin{array}{l}\text { Model } 1 \\
\text { Variable }\end{array}$} & \multicolumn{3}{|c|}{$\mathrm{Ln} \_\mathrm{IA}_{\mathrm{it}}=\beta_{0}+\beta_{1} \mathrm{ICDs}_{\mathrm{it}}+\sum_{i=1}^{j} \alpha_{\mathrm{j}} \delta_{\mathrm{it}}+\varepsilon_{\mathrm{t}}$} \\
\hline & Expected Sign & Estimated Coefficient & t Value \\
\hline \multicolumn{3}{|l|}{ Variable of Interest } & $18.50 * * *$ \\
\hline ICDs & + & .1941 & $2.03 * *$ \\
\hline \multicolumn{4}{|c|}{ Firm-Specific Characteristics } \\
\hline ROA & - & -.1757 & $-1.89 *$ \\
\hline ASSETS & - & -.0922 & $-5.14 * * *$ \\
\hline MTB & - & -.0750 & $-5.83 * * *$ \\
\hline DA & + & .0025 & .13 \\
\hline REG & + & .1508 & $2.33 * *$ \\
\hline LQ & - & -.0417 & $-2.37 * *$ \\
\hline LOSS & + & .1622 & $5.90 * * *$ \\
\hline AUD_D & + & .0131 & .34 \\
\hline AUD_R & + & .1861 & $1.70 *$ \\
\hline BIG_6 & - & .1163 & 1.07 \\
\hline \multicolumn{4}{|c|}{ Loan-Specific Characteristics } \\
\hline S_REVOLVERS & - & -.4546 & $-8.35 * * *$ \\
\hline L_REVOLVERS & + & -.3072 & $-7.32 * * *$ \\
\hline BANK_LENDERS & + & .1851 & $1.95 *$ \\
\hline INSTIT_LENDERS & - & .0263 & .41 \\
\hline CAP & ? & -.0357 & -.30 \\
\hline CORP & ? & .0441 & 1.42 \\
\hline CP_PACKUP & ? & -.2506 & $-4.82 * * *$ \\
\hline DEBT & + & .0911 & $1.69 *$ \\
\hline TAKEOVER & + & .0730 & 1.10 \\
\hline OTHER_LOANS & $?$ & .0015 & .02 \\
\hline SECURED & - & .3919 & $12.26^{* * *}$ \\
\hline SPONSORED & - & .2906 & $4.80^{* * *}$ \\
\hline RATING_CAT & + & .2372 & $8.51 * * *$ \\
\hline SYND & - & -.0014 & -.60 \\
\hline MATURITY & - & .0019 & $2.16^{* * *}$ \\
\hline LOAN_SIZE & - & -.0356 & $-2.08 * *$ \\
\hline COVEN & $?$ & .0255 & .82 \\
\hline SOX 404 & - & -.2450 & $-2.46^{* *}$ \\
\hline IND & Included & & \\
\hline F Value & 95.3516 & & \\
\hline P Value & 0.0000 & & \\
\hline Adjusted $\mathrm{R}^{2}$ & $65.35 \%$ & & \\
\hline $\mathrm{N}$ & 1802 & & \\
\hline
\end{tabular}




\subsubsection{H1b: The effect of ICDs disclosure under Section 302 and Section 404 on Information Asymmetry}

Prior research concludes that ICDs reported under section 302 are associated with negative stock returns (Gupta and Nayar 2006; Beneish, Billings and Hodder 2008) and higher cost of capital (Ashbaugh-Skaife, Collins, Kinney, and LaFond, 2009.) My results in Table 13 are consistent with prior research and show a strong statistically significant positive association with a positive slope of .399 and significant at $1 \%$ with p-value $<0.01$ between the disclosure of ICDs under section 302 and IA. The model is statistically significant at $1 \%$ with p-vale $<0.01$. The model explains $69.07 \%$ of the variations in the IA as measured by Adjusted $\mathrm{R}^{2}$. I used a subset of samples of 398 firm-year observation with only ICDs reported under both sections 302 and 404 to test model 2. I included in the regression the same large pool of control variables to control for firm and loan-specific characteristics. The results show also that IA has a negative significant association with ROA, Assets, regulated industries (REG), MTB, syndication, and loan size.

This latter result supports the notion that big firms, high performing of firms, well established, more syndicated to multiple lenders and large loans and profitable firms are experiencing lower IA than other small firms, low performing of firms. According to model 2, there is a statistical positive significant association between IA has and loss firms, Big 6, identity of lenders, maturity, secured, sponsored and rated loans. These positive associations imply an increase in the magnitude of IA as an increasing function of these control variables. Overall, the results of table 13 support $\mathrm{H} 2$ a that in the secondary loan market, firms with Internal Control Deficiencies reported under section 302 have significantly higher information asymmetry than firms with Internal Control Deficiencies reported under section 404. 
The results in this section are consistent with the findings of Ashbaugh-Skaife, Collins, Kinney, and LaFond (2009) who find a positive association between the cost of capital and disclosure of material weaknesses under sections 302. However, it is not contrary to the findings of Ogneva, Subramanyam, and Raghunandan (2007) who find no association between the disclosure of ICMW under section 404 and cost of capital, nor is it consistent with Botosan (1997) who also finds no relation between disclosure and the cost of capital in the pre-SOX 2002 period. Overall, results suggest that the market response to IC quality is dependent on audit quality as argued by Gupta and Nayar (2006) and Beneish et al. (2008) because section 302 (unaudited ICDs) showed a positive association with IA, while section 404 (audited ICDs) showed a negative association with IA. Moreover, Kim and Park (2009) find that for a sample of firms that disclose internal control deficiencies under section 302, the abnormal stock returns are negatively associated with changes in market uncertainty. My results also support the notion of the study made by Kim and Park (2009), which suggest negative consequences of the disclosure of ICD to the market. 
TABLE 13

Regression of Information Asymmetry on Internal Control Deficiencies under Section 302

\begin{tabular}{|c|c|c|c|c|}
\hline \multirow[b]{2}{*}{ Variable } & \multirow[t]{2}{*}{ Model 2} & \multicolumn{3}{|c|}{$\mathrm{Ln} \_\mathrm{IA}_{\mathrm{it}}=\beta_{0}+\beta_{1} \mathrm{ICDs} \_302_{\mathrm{it}}+\sum_{i=1}^{j} \alpha_{\mathrm{j}} \delta_{\mathrm{it}}+\varepsilon_{\mathrm{t}}$} \\
\hline & & Expected Sign & Estimated Coefficient & t Value \\
\hline Intercept & & $?$ & 7.8272 & $8.44 * * *$ \\
\hline \multicolumn{5}{|l|}{ Variable of Interest } \\
\hline ICDs_302 & & + & .3986 & $4.18 * * *$ \\
\hline \multicolumn{5}{|c|}{ Firm-Specific Characteristics } \\
\hline ROA & & - & -.4719 & $-2.87 * * *$ \\
\hline ASSETS & & - & -.1157 & $-2.99 * * *$ \\
\hline MTB & & - & -.0353 & -1.12 \\
\hline DA & & + & -.0669 & -1.36 \\
\hline REG & & + & -.2326 & $-1.67 *$ \\
\hline LQ & & - & -.0246 & -.69 \\
\hline LOSS & & + & .1476 & $2.30 * *$ \\
\hline AUD D & & + & -.1038 & -1.06 \\
\hline AUD_R & & + & .0804 & .71 \\
\hline BIG_6 & & - & .3822 & $1.83 *$ \\
\hline \multicolumn{5}{|c|}{ Loan-Specific Characteristics } \\
\hline S_REVOLVERS & & - & .0925 & .64 \\
\hline L_REVOLVERS & & + & -.0260 & -.30 \\
\hline BANK_LENDERS & & + & .7442 & $4.50 * * *$ \\
\hline INSTIT_LENDERS & & - & .3245 & $2.79 * * *$ \\
\hline $\mathrm{CORP}$ & & ? & .1200 & $1.92 *$ \\
\hline CP_PACKUP & & ? & .1097 & .62 \\
\hline DEBT & & + & .1098 & .93 \\
\hline TAKEOVER & & + & -.4590 & $-3.75 * * *$ \\
\hline OTHER LOANS & & ? & .1330 & .64 \\
\hline SECURED & & - & .3358 & $4.94 * * *$ \\
\hline SPONSORED & & - & .3168 & $3.43 * * *$ \\
\hline RATING_CAT & & + & .3142 & $3.34 * * *$ \\
\hline SYND & & - & -.0193 & $-2.32 * *$ \\
\hline MATURITY & & - & .0059 & $3.74 * * *$ \\
\hline LOAN_SIZE & & - & -.1027 & $-2.40 * *$ \\
\hline COVEN & & $?$ & -.0090 & -.13 \\
\hline IND & & Included & & \\
\hline F Value & & 27.0780 & & \\
\hline P Value & & 0.0000 & & \\
\hline Adjusted $\mathrm{R}^{2}$ & & $69.07 \%$ & & \\
\hline $\mathrm{N}$ & & 398 & & \\
\hline
\end{tabular}




\subsubsection{H2a: The Effect of ICMWs Disclosure on Information Asymmetry}

Table 14 documents a negative, but non-statistically significant, association between the disclosure of ICMWs and IA. Overall, the model is statistically significant at $1 \%$ with p-vale < 0.01 . The model explains $69.07 \%$ of the variations in the IA as measured by Adjusted $\mathrm{R}^{2}$. I used a subset of samples of 398 firm-year observation with only ICMWs reported under both sections 302 and 404 to test model 4. I included in the regression the same large pool of control variables to control for firm and loan-specific characteristics. Results on the association between the control variables and IA are quite similar to that in models 1 and 2. Overall, the results in model 3 do not support, nor refute, my $(H 2 a)$, which states that, in the secondary loan market, firms with Internal Control Material Weaknesses have significantly higher information asymmetry than those with Significant and/or Control Deficiencies post SOX 2002. This hypothesis is supposed to measure the association between the rank of severity of ICDs as measured by the presence of ICMWs and IA. Although the hypothesized relationship in H2a is not supported by the results of the statistical analysis in Table 14, Table 15 tests the level of severity of ICDs as measured by the Company Level (CL) versus Account-Specific (AS) Internal Control Deficiencies. Nevertheless, Table 15 supports my prediction that the disclosure of severe types of ICDs as measured by CL is positively associated with IA. 
TABLE 14

Regression of Information Asymmetry on Internal Control Material Weaknesses

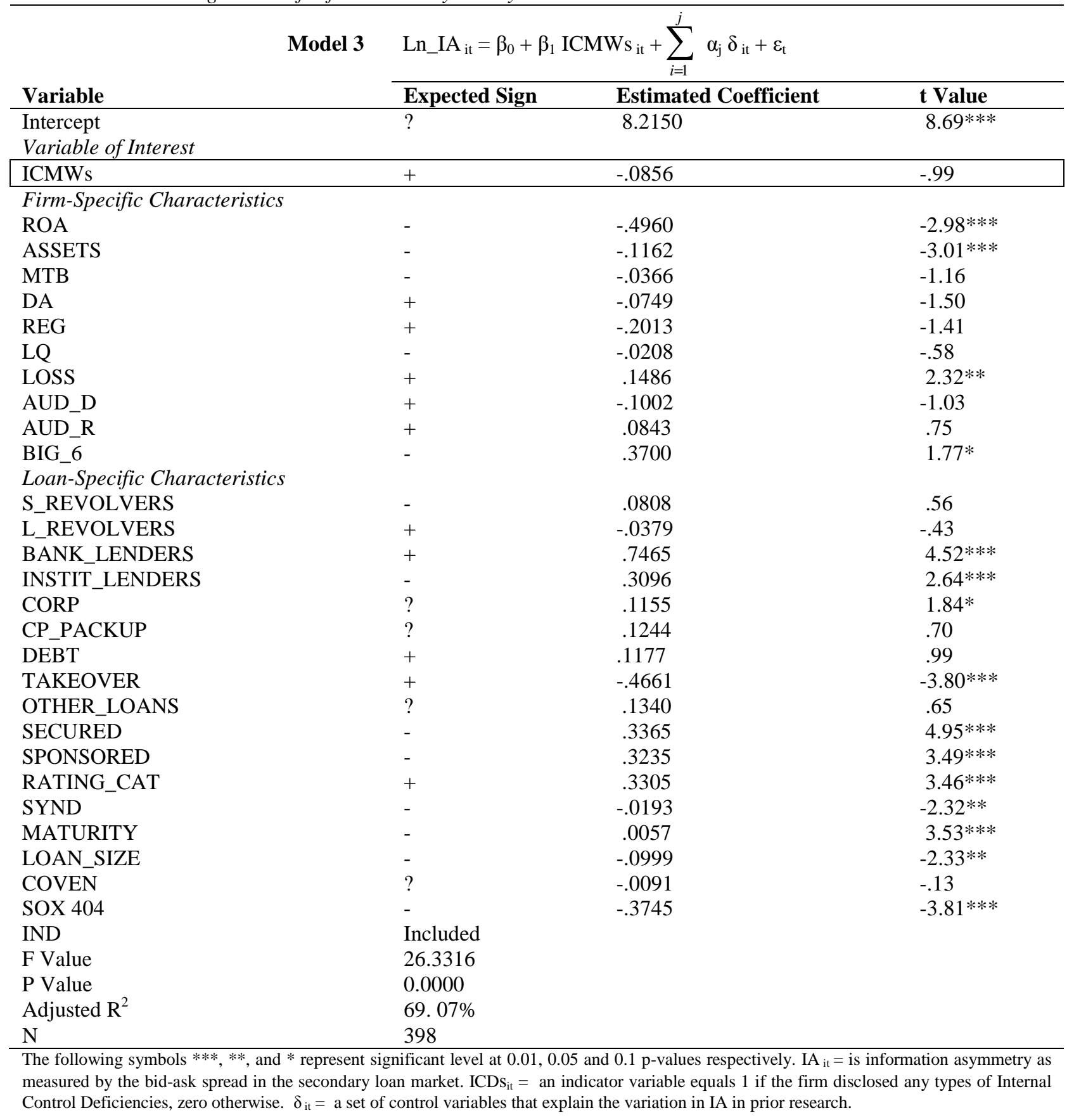




\subsubsection{H2b: The Effect of Company Level ICDs Disclosure on Information}

\section{Asymmetry}

Table 15 summarizes the results of the association between the disclosure of more severe types of ICDs such as the Company Level versus Account Specific and IA. I used a subset of samples of 398 firm-year observation with only ICDs reported under both sections 302 and 404 to test model 4. I then manually coded firms with ICDs into either CL weaknesses or AS weaknesses ${ }^{30}$. It is hypothesized that disclosure of severe types of IC weaknesses may lead banks and short-term lenders to discount the collateral potential of the borrowing firms' financial assets (Gupta and Nayar, 2006) and trigger a lower debt rating thus increasing the probability of default and/or higher borrowing costs (Moody's Investor Service, 2004; Fitch Rating, 2005), thus increasing market uncertainty (Beneish, Billings and Hodder 2008; Kim and park 2009.) In summary, prior research suggests that different types of IC weaknesses result in varying degrees of uncertainty. Overall, the more severe the IC weakness, the more likely investors will perceive higher information asymmetry. In this case, the disclosure of these IC weaknesses will be perceived by uninformed traders as requiring them to seek private information to reduce the information asymmetry. Conversely, this will induce informed traders to lessen their trading activities. The overall effect will be a subsequent increase in IA.

I expect various types of IC weaknesses to have varying impacts on information asymmetry in the secondary loan market. I will stratify IC weaknesses by type and investigate

\footnotetext{
${ }^{30}$ In categorizing the Internal Control Deficiencies as either Company Level (CL) or Account-Specific (AS), I classified weaknesses in internal control related to any accounts such as: inventory, accounts receivables, loan receivables, gain or loss recognition issues, liabilities, reserves, Tax expense, Depreciation, depletion or amortization issues, and financial derivatives as Account- Specific (AS) weaknesses in internal control. With the same token, I classified weaknesses in internal control related to company level issues such as: Acquisition, merger, disposal or reorganization issues Deferred, stock-based or executive compensation issues, Intercompany issues, Foreign, related party, Consolidation, affiliated and/or subsidies issues as Company-Level (CL) weaknesses in internal control. I then manually coded firms with CL with 1 and firms with AS with zero.
} 
their relationship to information asymmetry in the secondary loan market. Doyle, Ge and McVay (2007a) suggest that the determinants of material Internal Control Deficiencies vary according to the reasons for those weaknesses.

The results in table 15 show a strong statistically positive significant association at $1 \%$ between the disclosure of Company Level (CL) weaknesses and IA with a positive slope of .212. The model is statistically significant with p-vale $<0.01$ and the model explains $70.34 \%$ of the variations in the IA as measured by Adjusted $\mathrm{R}^{2}$. I included in the regression the same large pool of control variables to control for firm and loan-specific characteristics. Results on the association between control variables and IA are quite similar to what is documented in previously used regression models in this study. Overall, the results of Table 18 support the H2b hypothesis that in the secondary loan market, firms with company-level weaknesses have significantly higher information asymmetry than those with account-specific weaknesses post SOX 2002. 
TABLE 15

Regression of Information Asymmetry on Company-level Internal Control Deficiencies

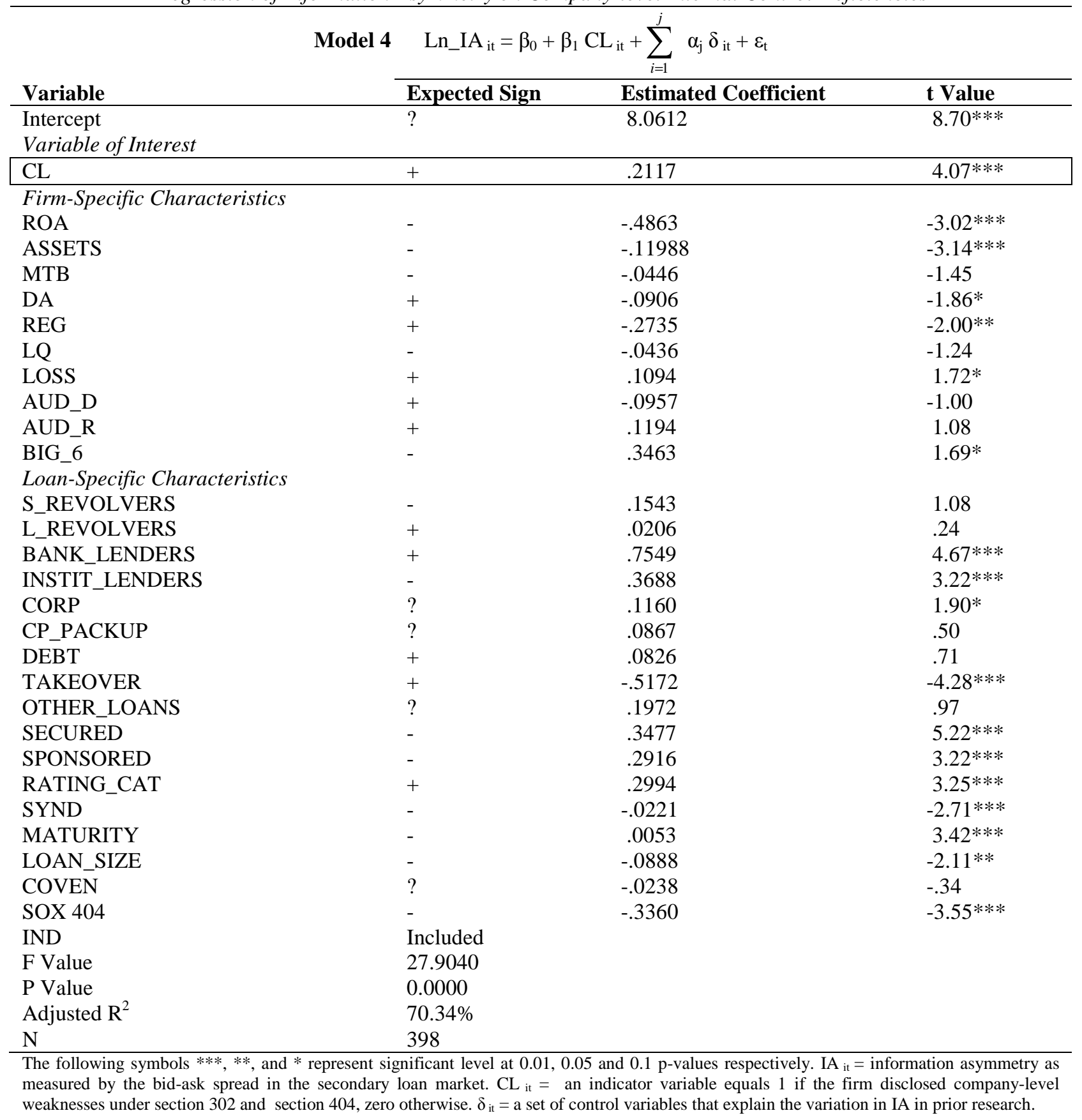




\subsubsection{H3: The Effect of IC Remediation on Information Asymmetry}

Table 16 summarizes the results of the association between the remediation of Internal Control Deficiencies and IA. I used a subset of samples of 398 firm-year observations with only ICDs reported under both sections 302 and 404 with their subsequent remediation to test model 5. I then manually coded firms that remediated part or all of their weaknesses in internal control with 1 and firms that did not remediate Internal Control Deficiencies with zero.

The results in Table 16 show a strong statistically significant negative association, at $1 \%$, between the disclosure of remediation of ICDs and IA. The slope of the association is .193. The model is statistically significant at $1 \%$ with p-vale $<0.01$. The model explains $74 \%$ of the variations in IA as measured by Adjusted $\mathrm{R}^{2}$. I included in the regression the same large pool of control variable to control for firm and loan specific characteristics. However, I added an additional control variable, which is Cash Flow from Operation (CFO) as a measure of investment in internal control because remediation requires more investment in internal control systems (Gupta and Nayar, 2006; Ashbaugh-Skaife, Collins, Kinney, and LaFond , 2008; Feng et al., 2009.) The results of the regression analysis shows a negative significant association between $\mathrm{CFO}$ and IA, implying that firms with a higher magnitude of CFO are experiencing lower IA, as measured by the average bid-ask spread. Results on the association between control variables and IA are quite similar to what is documented in previous regression models used in this study. Overall, the results of table 16 support my hypothesis $(H 3)$ that in the secondary loan market, firms that remediate their ICDs have significantly lower information asymmetry than firms that did not remediate their ICDs SOX 2002. 
TABLE 16

Regression of Information Asymmetry on Remediation of Internal Control Deficiencies

\begin{tabular}{|c|c|c|c|c|}
\hline \multirow[b]{2}{*}{ Variable } & \multirow[t]{2}{*}{ Model 5} & \multicolumn{3}{|c|}{$\mathrm{Ln}_{-} \mathrm{IA}_{\mathrm{it}}=\beta_{0}+\beta_{1} \mathrm{REM}_{\mathrm{it}}+\sum_{i=1}^{j} \alpha_{\mathrm{j}} \delta_{\mathrm{it}}+\varepsilon_{\mathrm{t}}$} \\
\hline & & Expected Sign & Estimated Coefficient & t Value \\
\hline $\begin{array}{l}\text { Intercept } \\
\text { variable of interest }\end{array}$ & & $?$ & 7.7125 & $8.71 * * *$ \\
\hline REM & & - & -.1927 & $-3.01 * * *$ \\
\hline \multicolumn{5}{|c|}{ Firm-Specific Characteristics } \\
\hline ROA & & - & -.4574 & $-3.03 * * *$ \\
\hline ASSETS & & - & .0046 & .12 \\
\hline МТВ & & - & .0321 & 1.07 \\
\hline DA & & + & -.0990 & $-2.18 * *$ \\
\hline REG & & + & -.1443 & -1.13 \\
\hline LQ & & - & .0938 & $2.63^{* * *}$ \\
\hline LOSS & & + & .1134 & $1.90 *$ \\
\hline AUD_D & & + & -.1373 & -1.53 \\
\hline AUD_R & & + & .1610 & 1.55 \\
\hline Ln_CFO & & - & -.2226 & $-8.23 * * *$ \\
\hline BIG_6 & & - & .0792 & .40 \\
\hline \multicolumn{5}{|c|}{ Loan-Specific Characteristics } \\
\hline S_REVOLVERS & & - & .0960 & .72 \\
\hline L_REVOLVERS & & + & -.0687 & -.85 \\
\hline BANK_LENDERS & & + & .6212 & $4.06 * * *$ \\
\hline INSTIT_LENDERS & & - & .2148 & $2.00 * *$ \\
\hline CORP & & $?$ & .0309 & .53 \\
\hline CP_PACKUP & & $?$ & -.0648 & -.40 \\
\hline DEBT & & + & .1295 & 1.18 \\
\hline TAKEOVER & & + & -.5113 & $-4.55 * * *$ \\
\hline OTHER_LOANS & & $?$ & .2419 & 1.26 \\
\hline SECURĒD & & - & .3716 & $5.95^{* * *}$ \\
\hline SPONSORED & & - & .2898 & $3.37 * * *$ \\
\hline RATING_CAT & & + & .2140 & $2.42 * *$ \\
\hline SYND & & - & -.0077 & -.98 \\
\hline MATURITY & & - & .0053 & $3.51 * * *$ \\
\hline LOAN_SIZE & & - & -.1415 & $-3.56^{* * *}$ \\
\hline COVEN & & ? & -.1367 & $-2.03 * *$ \\
\hline SOX 404 & & - & -.4282 & $-4.82 * * *$ \\
\hline IND & & Included & & \\
\hline F Value & & 32.3817 & & \\
\hline P Value & & 0.0000 & & \\
\hline Adjusted $\mathrm{R}^{2}$ & & $74.00 \%$ & & \\
\hline $\mathrm{N}$ & & 398 & & \\
\hline
\end{tabular}




\subsubsection{H4: The Moderating Effect of the Secondary Loan Market Characteristics on the Association between Information Asymmetry and ICDs}

The previous statistical analysis shows that the disclosure of ICDs exacerbates conditions of information asymmetry in the secondary loan market. One might pose an intriguing question in response to such results. Why such association exists in the secondary loan market and what would make such association unique in these market settings relative to other market settings found in the primary loan market or equity market?

Possible explanations for the documented positive significant association between Internal Control Deficiencies and information asymmetry in the secondary loan market are the unique characteristics of the secondary loan market. The secondary loan market is characterized by the existence of multiple lenders, various types of loans, debt covenants, credit rating, and different loan purposes. For example, the existence of credit rating of the firm and/or the loan in

the secondary loan market is expected to reflect the loan's creditworthiness and indicative of a higher firm value and performance. Therefore, I would expect a significant negative association between the interaction term of ICDs and the existence of credit rating and IA in the secondary loan market.

Ogneva, Subramanyam, and Raghunandan (2007) suggest that firms with internal control weakness post-SOX 404 and prior to AS5 have higher costs of equity capital. Nevertheless, the positive effect between the reporting of material weakness and cost of equity capital dissipates after controlling for firm-specific characteristics and analysts' forecasts bias, implying an indirect association between the disclosure of material weaknesses and the cost of equity capital. Additionally, in the secondary loan market research area, Sufi (2007) and Moerman (2008) find that participant-lender reputation mitigates, but does not eliminate, information asymmetry. 
The debt covenant plays a crucial role in the determination of the loan prices and hence the average bid-ask spread. The interaction term between ICDs and the debt covenant should presumably show a significant negative/positive association with IA in the secondary loan market. The same analogy can be applied to multiple lenders/arranges. IA for loans that are syndicated to a large number of lenders should be lower than that IA for loans that are syndicated to less number of lenders. Therefore, the interaction term of the ICDs and the number of lenders should show a significant negative association with IA in the secondary loan market.

In this section, I will try to explain the documented positive relationship between the disclosure of Internal Control Deficiencies and information asymmetry in the secondary loan market by focusing on three unique characteristics of the secondary loan market, namely, syndication, credit rating and debt covenants. My prediction is that the unique characteristics of the secondary loan market mitigate or moderate the association between ICDs and IA. In proving my conjectures, I then rerun the previous statistical analysis of the regression of IA on ICDs by focusing on the interaction term between the $\mathrm{ICD}_{\mathrm{s}}$ and three previously discussed loan-specific characteristics as my variables of interest. My expectation is that the source of the increasing magnitude of IA in the presence of the ICD variable is primarily due to the existence of smaller number of syndicated lenders, the absence of debt covenants and the absence of credit rating.

Tables 17-19 summarize the results of the additional regression models. Results of all three models seem to be fairly consistent with my prediction that the unique characteristics of the secondary loan market mitigate the positive significant association between ICDs and IA. All models are significant at $1 \%$ and their p-values are $<0.01$. While the disclosure of ICDs has a significant positive association with IA, the interaction term between ICDs and the number of lenders, the existence of credit rating, and the existence of debt covenants have statistically 
significant negatives associated with IA, suggesting a mediating effect of such unique characteristics on the association between the disclosure of ICDs and IA in the secondary loan market. 
TABLE 17

Regression of Information Asymmetry on the interaction term between ICDs and Number of Lenders (Syndication)

\begin{tabular}{|c|c|c|c|}
\hline \multirow[b]{2}{*}{ Variable } & \multicolumn{3}{|c|}{$\mathrm{Ln}_{-} \mathrm{IA}_{\mathrm{it}}=\beta_{0}+\beta_{1} \mathrm{ICDs}_{\mathrm{it}}+\beta_{2} \mathrm{SYND}_{\mathrm{it}}+\beta_{3} \mathrm{ICDs} * \mathrm{SYND}_{\mathrm{it}}+\sum_{i=1}^{j} \alpha_{\mathrm{j}} \delta_{\mathrm{it}}+\varepsilon_{\mathrm{t}}$} \\
\hline & Expected Sign & Estimated Coefficient & t Value \\
\hline \multicolumn{4}{|l|}{ variable of interest } \\
\hline ICDs & + & 0.3347 & $3.24 * * *$ \\
\hline SYND & $?$ & 0.0003 & 0.11 \\
\hline ICDs*SYND & - & -0.0184 & $-3.54 * * *$ \\
\hline \multicolumn{4}{|c|}{ Firm-Specific Characteristics } \\
\hline ROA & - & -0.1971 & $-2.13 * *$ \\
\hline ASSETS & - & -0.0898 & $-5.02 * * *$ \\
\hline MTB & - & -0.0743 & $-5.79 * * *$ \\
\hline DA & + & 0.0015 & 0.08 \\
\hline REG & + & 0.1447 & $2.25^{* *}$ \\
\hline LQ & - & -0.0431 & $-2.45^{* *}$ \\
\hline LOSS & + & 0.1592 & $5.81 * * *$ \\
\hline AUD_D & + & 0.0142 & 0.36 \\
\hline AUD_R & + & 0.1627 & 1.49 \\
\hline BIG_6 & - & 0.1597 & 1.47 \\
\hline \multicolumn{4}{|c|}{ Loan-Specific Characteristics } \\
\hline S_REVOLVERS & - & -0.4579 & $-8.45^{* * *}$ \\
\hline L_REVOLVERS & + & -0.3140 & $-7.53 * * *$ \\
\hline BANK_LENDERS & + & 0.1652 & $1.74 *$ \\
\hline INSTIT_LENDERS & - & -0.0011 & -0.02 \\
\hline CORP & ? & 0.0403 & 1.31 \\
\hline CP_PACKUP & $?$ & -0.2520 & $-4.87 * * *$ \\
\hline DEBT & + & 0.0962 & $1.79 *$ \\
\hline TAKEOVER & + & 0.0602 & 0.91 \\
\hline OTHER_LOANS & $?$ & 0.0105 & 0.14 \\
\hline SECUREDD & - & 0.3827 & $11.97 * * *$ \\
\hline SPONSORED & - & 0.2873 & $4.77 * * *$ \\
\hline RATING_CAT & + & 0.2391 & $8.61 * * *$ \\
\hline MATURITY & - & 0.0018 & $2.13 * *$ \\
\hline LOAN_SIZE & - & -0.0315 & $-1.85^{*}$ \\
\hline COVEN & $?$ & 0.0441 & 1.41 \\
\hline SOX 404 & - & -0.2498 & $-2.52 * *$ \\
\hline IND & Included & & \\
\hline F Value & 96.3665 & & \\
\hline P Value & 0.0000 & & \\
\hline Adjusted $\mathrm{R}^{2}$ & $65.59 \%$ & & \\
\hline $\mathrm{N}$ & 1802 & & \\
\hline
\end{tabular}


TABLE 18

Regression of Information Asymmetry on the interaction term between ICDs and Credit Rating

\begin{tabular}{|c|c|c|c|}
\hline \multirow[t]{2}{*}{ Model 6b } & \multicolumn{3}{|c|}{$\mathrm{Ln}_{-} \mathrm{IA}_{\mathrm{it}}=\beta_{0}+\beta_{1} \mathrm{ICDs}_{\mathrm{it}}+\beta_{2} \mathrm{RATING}_{\mathrm{it}}+\beta_{3} \mathrm{ICDs} * \mathrm{RATING}_{\mathrm{it}}+\sum_{i=1}^{j} \alpha_{\mathrm{j}} \delta_{\mathrm{it}}+\varepsilon_{\mathrm{t}}$} \\
\hline & Expected Sign & Estimated Coefficient & t Value \\
\hline \multicolumn{4}{|l|}{ variable of interest } \\
\hline ICDs & + & 0.2845 & $2.70 * * *$ \\
\hline RATING $^{(\mathrm{A})}$ & - & 0.2230 & $5.33 * * *$ \\
\hline ICDs*RATING & - & -0.1440 & $-2.28 * *$ \\
\hline \multicolumn{4}{|c|}{ Firm-Specific Characteristics } \\
\hline ROA & - & -0.2033 & $-2.21 * *$ \\
\hline ASSETS & - & -0.1139 & $-6.24 * * *$ \\
\hline MTB & - & -0.0727 & $-5.69 * * *$ \\
\hline DA & + & -0.0009 & -0.05 \\
\hline REG & + & 0.1328 & $2.07 * *$ \\
\hline LQ & - & -0.0358 & $-2.04 * *$ \\
\hline LOSS & + & 0.1552 & $5.68 * * *$ \\
\hline AUD_D & + & 0.0088 & 0.23 \\
\hline AUD_R & + & 0.1474 & 1.35 \\
\hline BIG_6 & - & 0.0741 & 0.68 \\
\hline \multicolumn{4}{|c|}{ Loan-Specific Characteristics } \\
\hline S_REVOLVERS & - & -0.4575 & $-8.48 * * *$ \\
\hline L_REVOLVERS & + & -0.3178 & $-7.64 * * *$ \\
\hline BANK_LENDERS & + & 0.1732 & $1.84 *$ \\
\hline INSTIT_LENDERS & - & -0.0154 & -0.24 \\
\hline CORP & ? & 0.0390 & 1.28 \\
\hline CP_PACKUP & $?$ & -0.2446 & $-4.75 * * *$ \\
\hline DEBT & + & 0.0839 & 1.56 \\
\hline TAKEOVER & + & 0.0545 & 0.83 \\
\hline OTHER_LOANS & ? & 0.0046 & 0.06 \\
\hline SECURED & - & 0.3607 & $11.18 * * *$ \\
\hline SPONSORED & - & 0.2625 & $4.34 * * *$ \\
\hline RATING_CAT & + & 0.2885 & $9.85 * * *$ \\
\hline SYND & - & -0.0005 & -0.20 \\
\hline MATURITY & - & 0.0015 & $1.76^{*}$ \\
\hline LOAN_SIZE & - & -0.0522 & $-3.01 * * *$ \\
\hline COVEN & $?$ & 0.0254 & 0.83 \\
\hline SOX 404 & - & -0.2315 & $-2.33 * *$ \\
\hline IND & Included & & \\
\hline F Value & 94.9811 & & \\
\hline P Value & 0.0000 & & \\
\hline Adjusted $\mathrm{R}^{2}$ & $65.59 \%$ & & \\
\hline $\mathrm{N}$ & 1802 & & \\
\hline
\end{tabular}

(A) The documented positive significant association between the existence of RATING and IA can be explained by the possible existence of multicollinearity between RATING and RATING_CAT. I rerun the model after excluding RATING_CAT and again got a positive significant association between the existence of credit rating and IA. I checked the multicollinearity statistics for the model after excluding RATING_CAT and I found a high collienarity between the interaction term of ICDs and the existence of credit rating and the existence of credit rating as. I then impute the positive sign of the RATING slope to the presence of multicollinearity.

The following symbols $* * *, * *$, and $*$ represent significant level at $0.01,0.05$ and $0.1 \mathrm{p}$-values respectively. IA $\mathrm{t}=$ the bid-ask spread in the secondary loan market. $\mathrm{ICD}_{\text {it }}=$ an indicator variable equals 1 if the firm disclosed any types of Internal Control Deficiencies, zero otherwise. RATING $_{\text {it }}=$ an indicator variable $=1$ for the presence of credit rating and 0 otherwise. ICDs*RATING it $^{*}=$ the interaction term between the existence of the credit rating and ICDs. $\delta_{i t}=$ a set of control variables that explain the variation in IA in prior research. 
TABLE 19

Regression of Information Asymmetry on the interaction term between ICDs and Debt Covenants

\begin{tabular}{|c|c|c|c|}
\hline \multirow[t]{2}{*}{ Model 6c } & \multicolumn{3}{|c|}{$\mathrm{Ln}_{-} \mathrm{IA}_{\mathrm{it}}=\beta_{0}+\beta_{1} \mathrm{ICDs}_{\mathrm{it}}+\beta_{2} \mathrm{COVEN}_{\mathrm{it}}+\beta_{3} \mathrm{ICDs}^{*} \mathrm{COVEN}_{\mathrm{it}}+\sum_{i=1}^{j} \alpha_{\mathrm{j}} \delta_{\mathrm{it}}+\varepsilon_{\mathrm{t}}$} \\
\hline & Expected Sign & Estimated Coefficient & t Value \\
\hline \multicolumn{4}{|l|}{ variable of interest } \\
\hline ICDs & + & 0.4116 & $3.68 * * *$ \\
\hline COVEN & $?$ & 0.0832 & $2.41 * *$ \\
\hline ICDs*COVEN & - & -0.2552 & $-3.70 * * *$ \\
\hline \multicolumn{4}{|c|}{ Firm-Specific Characteristics } \\
\hline ROA & - & -0.1694 & $-1.84 *$ \\
\hline ASSETS & - & -0.0827 & $-4.58 * * *$ \\
\hline MTB & - & -0.0722 & $-5.62 * * *$ \\
\hline DA & + & 0.0053 & 0.28 \\
\hline REG & + & 0.1706 & $2.64 * * *$ \\
\hline LQ & - & -0.0453 & $-2.58 * *$ \\
\hline LOSS & + & 0.1723 & $6.26 * * *$ \\
\hline AUD_D & + & 0.0078 & 0.20 \\
\hline AUD_R & + & 0.1709 & 1.57 \\
\hline BIG_6 & - & 0.0796 & 0.73 \\
\hline \multicolumn{4}{|c|}{ Loan-Specific Characteristics } \\
\hline S_REVOLVERS & - & -0.4665 & $-8.60 * * *$ \\
\hline L_REVOLVERS & + & -0.3204 & $-7.66 * * *$ \\
\hline BANK_LENDERS & + & 0.1709 & $1.81^{*}$ \\
\hline INSTIT_LENDERS & - & 0.0013 & 0.02 \\
\hline CORP & $?$ & 0.0456 & 1.48 \\
\hline CP_PACKUP & ? & -0.2534 & $-4.90 * * *$ \\
\hline DEBT & + & 0.0847 & 1.58 \\
\hline TAKEOVER & + & 0.0678 & 1.02 \\
\hline OTHER_LOANS & $?$ & 0.0185 & 0.24 \\
\hline SECURĒD & - & 0.4000 & $12.53 * * *$ \\
\hline SPONSORED & - & 0.2856 & $4.74 * * *$ \\
\hline RATING_CAT & + & 0.2351 & $8.47 * * *$ \\
\hline SYND & - & -0.0010 & -0.43 \\
\hline MATURITY & - & 0.0017 & $1.94 *$ \\
\hline LOAN_SIZE & - & -0.0391 & $-2.29 * *$ \\
\hline SOX 404 & - & -0.2837 & $-2.84 * * *$ \\
\hline IND & Included & & \\
\hline F Value & 96.4664 & & \\
\hline P Value & 0.0000 & & \\
\hline Adjusted $\mathrm{R}^{2}$ & $65.62 \%$ & & \\
\hline $\mathrm{N}$ & 1802 & 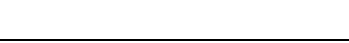 & 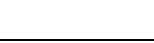 \\
\hline
\end{tabular}




\subsection{Additional Analyses:}

The Moderating Effect of the Secondary Loan Market Characteristics on the Association between Information Asymmetry and Severity of Internal Control Deficiencies

Based on prior research (Sufi, 2007; Moerman, 2008; Ball, Bushman, and Vasvari, 2008; Lee and Mullineaux, 2004), which documents that loan specific characteristics are having a significant association with information asymmetry, I would expect that the interaction effect between severity of internal control weaknesses as measured by CL and loan-specific characteristics, namely, syndication, credit rating and debt covenants, to have a significant association with IA in the secondary loan market. However, I am not expecting a specific direction between IA and the interaction term because the asymmetric information emitting from the problem severity of internal control is not easy to predict. My opinion is based on prior research (e.g., Beneish, Billings and Hodder 2008; Kim and Park 2009), which suggests that different types of IC weaknesses result in varying degrees of uncertainty. In this section, I test whether in the secondary loan market, loan-specific characteristics, namely, credit rating, debt covenants, and syndication mitigate the association between the severity of internal weaknesses and information asymmetry. I use the below model to test these relationships:

$$
\mathrm{IA}_{\mathrm{it}}=\beta_{0}+\beta_{1} \mathrm{CL}_{\mathrm{it}}+\beta_{2} \mathrm{LS} \_\mathrm{CHAR} \text { it }+\beta_{3} \mathrm{CL} * \mathrm{LS} \_C H A R_{\mathrm{it}}+\sum_{i=1}^{j} \alpha_{\mathrm{j}} \delta_{\mathrm{it}}+\varepsilon_{\mathrm{t}}
$$

Where

$\mathrm{IA}_{\mathrm{it}}=$ is information asymmetry as measured by the bid-ask spread in the secondary loan market.

$\mathrm{CL}_{\mathrm{it}}=$ is an indicator variable equals 1 if the firm disclosed company-level weaknesses under section 302 or section 404, zero otherwise.

LS_CHAR $\mathrm{it}_{\mathrm{it}}=$ syndication or number of lenders, the availability of credit rating and the existence of debt covenants. $^{31}$

CL*LS_CHAR $\mathrm{it}_{\mathrm{t}}=$ the interaction term between ICDs and LS_CHAR $\mathrm{it}_{\text {. }}$

$\delta_{i t}=$ is a set of control variables that explain the variation in IA in prior research.

\footnotetext{
${ }^{31}$ Same footnote as above.
} 
Tables 20-22 summarize the moderating effect of the secondary loan market characteristics on the association between information asymmetry and severity of internal control deficiencies. All models are statistically significant at $1 \%$ and have p-values $<0.01$. They explain the, on average, $70 \%$ of the variations in the IA in the secondary loan market. Overall, the interaction term between loan-specific characteristics does not show a consistent direction on whether it mitigates the IA. In Table 20, the results of model $7 \mathrm{a}$, which use the interaction between CL and loan syndication as an independent variable of interest, show no statistical association between the interaction term and IA, suggesting no impact of loan syndication on IA in the present of CL as a severe type of ICDs. Model $7 \mathrm{~b}$ in Table 21, however, shows a statistically positive significant association between the interaction term between CL and debt rating and IA, suggesting that the existence of debt rating does not lessen the IA in the presence of CL internal control deficiencies. Surprisingly, model 6c in Table 22 shows a statistically negative association between the interaction term between CL and debt covenants and IA, suggesting that the existence of debt covenants mitigates, but does not eliminate, the IA in the presence of CL internal control deficiencies. These latter results are consistent with findings by Bradley and Robert (2004) who suggest a positive impact of the existence of debt covenants in the loan arrangements. Theoretically, the existence of debt covenants mitigates the asymmetric information between lead arranger and participant lenders because it restricts the earnings manipulation and provides reliable and quality financial reporting, which decreases the asymmetric information. 
TABLE 20

Regression of Information Asymmetry on the interaction term between ICDs and Number of Lenders (Syndication)

\begin{tabular}{|c|c|c|c|}
\hline \multirow[t]{2}{*}{ Model 7a } & \multicolumn{3}{|c|}{$\mathrm{Ln}_{-} \mathrm{IA}_{\mathrm{it}}=\beta_{0}+\beta_{1} \mathrm{CL}_{\mathrm{it}}+\beta_{2} \mathrm{SYND}_{\mathrm{it}}+\beta_{3} \mathrm{CL} * \mathrm{SYND}_{\mathrm{it}}+\sum_{i=1}^{j} \alpha_{\mathrm{j}} \delta_{\mathrm{it}}+\varepsilon_{\mathrm{t}}$} \\
\hline & Expected Sign & Estimated Coefficient & t Value \\
\hline \multicolumn{4}{|l|}{$\begin{array}{l}\text { Intercept } \\
\text { variable of interest }\end{array}$} \\
\hline $\mathrm{CL}$ & + & 0.1619 & $1.98^{* *}$ \\
\hline SYND & - & -0.0252 & $-2.78 * * *$ \\
\hline CL*SYND & $?$ & 0.0064 & 0.79 \\
\hline \multicolumn{4}{|l|}{ Firm-Specific Characteristics } \\
\hline ROA & - & -0.4650 & $-2.84 * * *$ \\
\hline ASSETS & - & -0.1148 & $-3.00 * * *$ \\
\hline MTB & - & -0.0440 & -1.42 \\
\hline DA & + & -0.0901 & $-1.85^{*}$ \\
\hline REG & + & -0.2667 & $-1.95 *$ \\
\hline LQ & - & -0.0421 & -1.19 \\
\hline LOSS & + & 0.1108 & $1.74 *$ \\
\hline AUD_D & + & -0.0894 & -0.93 \\
\hline AUD_R & + & 0.1176 & 1.06 \\
\hline BIG_6 & - & 0.3436 & $1.68 *$ \\
\hline \multicolumn{4}{|l|}{ Loan-Specific Characteristics } \\
\hline S_REVOLVERS & - & 0.1598 & 1.12 \\
\hline L_REVOLVERS & + & 0.0249 & 0.29 \\
\hline BANK_LENDERS & + & 0.7624 & $4.70^{* * *}$ \\
\hline INSTIT_LENDERS & - & 0.3700 & $3.23 * * *$ \\
\hline $\mathrm{CORP}^{-}$ & $?$ & 0.1174 & $1.92 *$ \\
\hline CP_PACKUP & $?$ & 0.0859 & 0.50 \\
\hline DEBT & + & 0.0805 & 0.69 \\
\hline TAKEOVER & + & -0.5136 & $-4.25 * * *$ \\
\hline OTHER_LOANS & $?$ & 0.1867 & 0.91 \\
\hline SECURED & - & 0.3424 & $5.11 * * *$ \\
\hline SPONSORED & - & 0.2972 & $3.27 * * *$ \\
\hline RATING_CAT & + & 0.3114 & $3.33 * * *$ \\
\hline MATURITY & - & 0.0053 & $3.40 * * *$ \\
\hline LOAN_SIZE & - & -0.0890 & $-2.12 * *$ \\
\hline COVEN & $?$ & -0.0248 & -0.35 \\
\hline SOX 404 & - & -0.3360 & $-3.55 * * *$ \\
\hline IND & Included & & \\
\hline F Value & 27.1172 & & \\
\hline P Value & 0.0000 & & \\
\hline Adjusted $\mathrm{R}^{2}$ & $70.31 \%$ & & \\
\hline $\mathrm{N}$ & 398 & 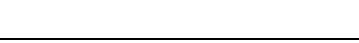 & \\
\hline
\end{tabular}


TABLE 21

Regression of Information Asymmetry on the interaction term between ICDs and Credit Rating

\begin{tabular}{|c|c|c|c|}
\hline \multirow[t]{2}{*}{ Model 7b } & \multicolumn{3}{|c|}{$\mathrm{Ln} \_I A_{\text {it }}=\beta_{0}+\beta_{1} \mathrm{CL}_{\mathrm{it}}+\beta_{2} \mathrm{RATING}_{\mathrm{it}}+\beta_{3} \mathrm{CL}^{*} \mathrm{RATING}_{\mathrm{it}}+\sum_{i=1}^{J} \alpha_{\mathrm{j}} \delta_{\mathrm{it}}+\varepsilon_{\mathrm{t}}$} \\
\hline & Expected Sign & Estimated Coefficient & t Value \\
\hline Intercept & $?$ & 8.7445 & $9.45 * * *$ \\
\hline \multicolumn{4}{|l|}{ variable of interest } \\
\hline $\mathrm{CL}$ & + & -0.1465 & $-1.65^{*}$ \\
\hline RATING & - & 0.0864 & 1.20 \\
\hline CL *RATING & $?$ & 0.4729 & $4.50 * * *$ \\
\hline \multicolumn{4}{|c|}{ Firm-Specific Characteristics } \\
\hline $\mathrm{ROA}$ & - & -0.5175 & $-3.75 * * *$ \\
\hline ASSETS & - & -0.1235 & $-3.57 * * *$ \\
\hline MTB & - & -0.0157 & -0.80 \\
\hline DA & + & -0.1203 & $-2.15 * *$ \\
\hline REG & + & -0.2733 & $-1.78 *$ \\
\hline LQ & - & -0.0582 & -1.38 \\
\hline LOSS & + & 0.1268 & $2.35 * *$ \\
\hline AUD_D & + & -0.0861 & -0.92 \\
\hline AUD_R & + & 0.0945 & 0.68 \\
\hline BIG_6 & - & 0.3245 & 0.73 \\
\hline \multicolumn{4}{|c|}{ Loan-Specific Characteristics } \\
\hline S_REVOLVERS & - & 0.1245 & 0.90 \\
\hline L_REVOLVERS & + & -0.0495 & -0.58 \\
\hline BANK_LENDERS & + & 0.5954 & $3.73 * * *$ \\
\hline INSTIT_LENDERS & - & 0.2035 & $1.79 *$ \\
\hline CORP & $?$ & 0.1278 & $2.16 * *$ \\
\hline CP_PACKUP & $?$ & 0.1750 & 1.05 \\
\hline DEBT & + & 0.0564 & 0.50 \\
\hline TAKEOVER & + & -0.3816 & $-3.21 * * *$ \\
\hline OTHER_LOANS & $?$ & 0.1175 & 0.59 \\
\hline SECURED & - & 0.3471 & $5.31 * * *$ \\
\hline SPONSORED & - & 0.2279 & $2.57 * *$ \\
\hline RATING_CAT & + & 0.3535 & $3.91 * * *$ \\
\hline SYND & - & -0.0238 & $-3.02 * * *$ \\
\hline MATURITY & & 0.0056 & $3.75 * * *$ \\
\hline LOAN_SIZE & - & -0.1323 & $-3.18 * * *$ \\
\hline COVEN & $?$ & 0.0344 & 0.50 \\
\hline SOX 404 & - & -0.2531 & $-2.75 * * *$ \\
\hline IND & Included & & \\
\hline F Value & 29.3961 & & \\
\hline P Value & 0.0000 & & \\
\hline Adjusted $\mathrm{R}^{2}$ & $72.58 \%$ & & \\
\hline $\mathrm{N}$ & 398 & & \\
\hline
\end{tabular}


TABLE 22

Regression of Information Asymmetry on the interaction term between ICDs and Debt Covenants

\begin{tabular}{|c|c|c|c|}
\hline \multirow[t]{2}{*}{ Model 7c } & \multicolumn{3}{|c|}{$\mathrm{Ln}_{-} \mathrm{IA}_{\mathrm{it}}=\beta_{0}+\beta_{1} \mathrm{CL}_{\mathrm{it}}+\beta_{2} \mathrm{COVEN}_{\mathrm{it}}+\beta_{3} \mathrm{CL} * \mathrm{COVEN}_{\mathrm{it}}+\sum_{i=1}^{j} \alpha_{\mathrm{j}} \delta_{\mathrm{it}}+\varepsilon_{\mathrm{t}}$} \\
\hline & Expected Sign & Estimated Coefficient & t Value \\
\hline $\begin{array}{l}\text { Intercept } \\
\text { variable of interest }\end{array}$ & $?$ & 8.1431 & $8.85^{* * *}$ \\
\hline CL & + & 0.4247 & $4.43 * * *$ \\
\hline COVEN & ? & 0.0421 & 0.57 \\
\hline CL $*$ COVEN & $?$ & -0.3079 & $-2.64 * * *$ \\
\hline \multicolumn{4}{|c|}{ Firm-Specific Characteristics } \\
\hline ROA & - & -0.4643 & $-2.90^{* * * *}$ \\
\hline ASSETS & - & -0.1211 & $-3.23 * * *$ \\
\hline MTB & - & -0.0329 & -1.06 \\
\hline $\mathrm{DA}$ & + & -0.0939 & $-1.95^{*}$ \\
\hline REG & + & -0.2283 & $-1.67 *$ \\
\hline LQ & - & -0.0422 & -1.21 \\
\hline LOSS & + & 0.1272 & $2.01 * *$ \\
\hline AUD_D & + & -0.0821 & -0.86 \\
\hline AUD_R & + & 0.1226 & 1.12 \\
\hline BIG_6 & - & 0.3750 & $1.85^{*}$ \\
\hline \multicolumn{4}{|c|}{ Loan-Specific Characteristics } \\
\hline S_REVOLVERS & - & 0.1120 & 0.79 \\
\hline L_REVOLVERS & + & 0.0060 & 0.07 \\
\hline BANK_LENDERS & + & 0.6765 & $4.15^{* * *}$ \\
\hline INSTIT_LENDERS & - & 0.3111 & $2.70 * * *$ \\
\hline $\mathrm{CORP}^{-}$ & $?$ & 0.1157 & $1.91^{*}$ \\
\hline CP_PACKUP & $?$ & 0.1175 & 0.68 \\
\hline DEBT & + & 0.1270 & 1.09 \\
\hline TAKEOVER & + & -0.4985 & $-4.15^{* * * *}$ \\
\hline OTHER_LOANS & ? & 0.2136 & 1.06 \\
\hline SECURED & - & 0.3862 & $5.71 * * *$ \\
\hline SPONSORED & - & 0.2530 & $2.78 * * *$ \\
\hline RATING_CAT & + & 0.2689 & $2.92 * * *$ \\
\hline SYND & - & -0.0203 & $-2.49^{* *}$ \\
\hline MATURITY & - & 0.0054 & $3.48 * * *$ \\
\hline LOAN_SIZE & - & -0.0902 & $-2.16^{* * *}$ \\
\hline SOX 404 & - & -0.3363 & $-3.58 * * *$ \\
\hline IND & Included & & \\
\hline F Value & 27.7695 & & \\
\hline P Value & 0.0000 & & \\
\hline Adjusted $\mathrm{R}^{2}$ & $70.82 \%$ & & \\
\hline $\mathrm{N}$ & 398 & & \\
\hline
\end{tabular}




\section{CHAPTER 7}

\section{SUMMARY AND CONCLUSION}

Limited research examines the impact of the quality of financial reporting on the secondary loan market (Ball, Bushman, and Vasvari 2008; Yu 2007; Gaul and Uysal, 2009; Moerman, 2008). To the best of my knowledge, examining the association between the disclosures of Internal Control quality on information asymmetry in the secondary loan market has been missing from this line of research. The main purpose of my study is to void the missing link in prior literature by testing the association between the disclosure of IC effectiveness and information asymmetry in the secondary loan market. An effective internal control system is an indication on the creditworthiness of the business environment and quality of financial reporting. Likewise, the presence of Internal Control Deficiencies is a sign that information provided to management for the decision-making process contains errors and that assets are not protected. Considering that assets are the collateral in any loan agreement, if these assets are not protected, then collateral will be viewed by creditors as overvalued assets. Therefore, to the extent that assets are not protected in a firm, creditors must account for the high risk associated with their investment in such firms by increasing the cost of borrowing. Likewise, credit rating agencies might lower the credit rating of such risky firms.

The primary objective of this study is tri-fold. First, it examines the association between the disclosure of the IC quality as a proxy for the firm's informational environment, and information asymmetry in the secondary loan market. Second, it identifies which types of IC weaknesses exacerbate conditions of information asymmetry in the secondary loan market. Third, it investigates whether firms that remediate or take corrective actions to address IC weaknesses lead to a reduction in information asymmetry in the market. Moreover, this study 
examines the effect of the loan specific characteristics in the secondary loan market on the association between internal control deficiencies and information asymmetry.

To the best of my knowledge, my study is the first to integrate the quality of IC and information asymmetry in the secondary loan market into one paradigm. My study extends numerous research on the association between the quality of accounting information and information asymmetry or cost of capital. For example, my study differs from and extends the study by Beneish, Billings and Hodder (2008). It also extends research on audit quality (DeAngelo, 1981, Teoh and Wong, 1993, Krishnan, 2005) because I compare two SOX 2002 provisions, section 302 is unaudited disclosure of ICDs and section 404 is audited disclosure of ICMWs. My work extends the study made by Moerman (2008), which finds that timely loss recognition, as a measure of financial reporting quality, decreases information asymmetry in the secondary loan market. Furthermore, my study extends research by Ashbaugh-Skaife, Collins, Kinney, and Lafond (2009), which argues that firms that failed to remediate their Internal Control Deficiencies (ICDs) receive an adverse SOX 404 opinion for the period after the ICDs disclosure, and consequently, experienced a higher cost of equity capital. Moreover, my study contributes to resolving the mixed evidence on the association between disclosure of material weaknesses and cost of capital.

To test my hypothesized relationships, I focus on four main predictions: the association between IC disclosure and information asymmetry, types of ICDs and information asymmetry, IC remediation and information asymmetry, and the effect of the loan-specific characteristics on the association between ICDs and information asymmetry. I based my prediction on the premise that the disclosure of ineffective ICs affects past, present and future financial reporting (Irving, 2006) because the internal control system is providing information to internal managers and 
market-wide participants for decision making for purposes such as buying and selling decisions, ratings by credit agencies, loan decisions, and rating firm creditworthiness.

The descriptive statistics of firms with ICDs reveal that firms with reported ICDs are generally small, poorer performers, financially weaker, and with higher market risk. These results are documented by multiple studies (Bryan and Lilien, 2005; Ge and McVay, 2005; Doyle, Ge and McVay 2007 a,b; Ashbaugh-Skaife, Collins, and Kinney, 2007, Ashbaugh-Skaife, Collins, Kinney, and LaFond, 2008). I also found strong evidence to support the claim that firms that disclose ICDs have significant positive association with IAs. The positive significant association between information asymmetry and ICDs suggests that the quality of accounting information matters in the secondary loan market. Additionally, on average, firms with ICDs are experiencing higher means and medians of IAs than firms with effective IC systems. In other words, effective IC systems serve the same function that other proxies of the quality of accounting information do, such as fill the role of timely loss recognition the secondary loan market (Moerman, 2008.)

Theoretically, proponents of section 302 might argue that it results in incremental value because it discloses Internal Control Deficiencies (ICD) which includes both material weaknesses and significant deficiencies. Nevertheless, I argue in my hypothesis development section and suggest, based on the results of my statistical analyses, that disclosing significant deficiencies causes variability in stakeholders' beliefs in two ways. First, stakeholders might perceive a reported significant deficiency as bad news as it might become a material weakness in the future. Second, stakeholders might also perceive a significant deficiency as good news as it bears low risk and they expect the firm to take remedial actions to mitigate the deficiency in the near future. Therefore, in this latter case, ICD signals to the market a lower prospective risk 
associated with investment with ICD firms. I base my prediction on prior research reporting that IC disclosure under section 302 increases market uncertainty (Kim and Park 2009; Beneish et al. 2008). ${ }^{32}$ I predict that disclosure of internal control quality under SOX 302 is incomplete due to the nature of voluntary disclosures associated with it. Incomplete disclosure hence stimulates investors and creditors to search for private information in an effort to reduce perceived information asymmetry. Moreover, voluntary disclosure is often perceived as less credible than mandatory, well-regulated disclosure. I found strong support for my prediction that in the secondary loan market, firms with Internal Control Deficiencies reported under section 302 are having more significant positive association with information asymmetry than firms with Internal Control Deficiencies reported under section 404.

This latter result is partially consistent with the findings of Ashbaugh-Skaife, Collins, Kinney, and LaFond (2009) who find a positive association between the cost of capital and disclosure of material weaknesses under sections 302 and 404 . However, it is contrary to the findings of Ogneva, Subramanyam, and Raghunandan (2007) who find no association under section 404 and Botosan (1997) who also finds no relation between disclosure and the cost of capital in the pre-SOX 2002 period. My results are also in line with those of Beneish, Billings and Hodder (2008) who find that the unaudited disclosure of material weakness causes an abnormal increase in the equity cost of capital and negative abnormal returns. However, I also found that audited disclosure of material weakness has an impact information asymmetry; unlike the documented results of Beneish et al. (2008), which suggest that SOX 404 audited disclosure does not affect the equity market. Overall, I found a negative significant association between the disclosure of ICDs under section 404 and information asymmetry.

\footnotetext{
${ }^{32}$ Kim and Park (2009), however, predict that some types of ICDs help reduce market uncertainty.
} 
Results on the association between the severity rank of ICDs and information asymmetry using the presence of ICMWs as a proxy for severity of Internal Control Deficiencies fail to provide support to my prediction, which states that firms with ICMWs will have a statistically positive significant association with IAs. However, the use of Company Level internal control as a measure of the severity of Internal Control Deficiencies provides strong support that firms with Company Level (CL) Internal Control Deficiencies are experiencing on average higher statistically significant means and medians IAs than firms with Accounting Specific (AS) Internal Control Deficiencies. Additionally, firms with CL have a positive significant association with IAs, suggesting that the disclosure of the severity of Internal Control Deficiencies exacerbates conditions of information asymmetry in the secondary loan market. Finally, using a sub-sample of firms with only ICDs and identifying firms that took remediation actions to correct the Internal Control Deficiencies reveals that there is a significant negative association between the remediation and IAs. Furthermore, I use the unique characteristics of the secondary loan market such as debt covenants, credit rating and number of lenders to explain the hypothesized relationship between the information asymmetry and the disclosure of Internal Control Deficiencies.

Possible explanations to the documented positive significant association between the existence of ICDs and IAs in the secondary loan market are the unique characteristics of the secondary loan market. To test this conjecture, I used the interaction term between three unique characteristics of the secondary loan market, namely, number of lenders or syndication, debt covenants and credit rating and ICDs as my variable of interest in a regression model that uses IA as the dependent variable and the interaction terms as well as other previously discussed control variables are independent variables. My prediction is that the existence of these unique 
characteristics mitigates the negative impact of the disclosure of ICDs on IA. Overall, I found statistical negative association between the interaction term of ICDs and the number of lenders and IA. Same negative association is documented for the interaction term of ICDs and credit rating, and IA and the interaction term of ICDs and debt covenants and IA. The latter result proves that the secondary loan market's unique characteristics improve the disclosure environment of ICDs and reduce the information asymmetry between lender and multiple arrangers.

I finally examine the moderating effect of the secondary loan market's characteristics on the association between information asymmetry and severity of internal control deficiencies. Overall, the results did not display consistent evidence on the mediating effect of loan-specific characteristics on IA. While syndication and CL interaction term did not show significant influence on IA, debt rating and CL interaction term showed positive significant association with IA, and debt covenants and CL interaction term documents a significant negative association with IA. Overall, I would conclude that loan-specific characteristics do not lessen the positive association between CL internal control deficiencies, as a severe type of ICD, and IA. My latter results are consistent with prior research (e.g., Beneish, Billings and Hodder 2008; Kim and Park 2009), which suggests that different types of IC weaknesses result in varying degrees of uncertainty. 


\section{REFERENCES}

Aboody, D. and Lev, B. 2000. Information asymmetry, R\&D, and insider gains. The Journal of Finance LV (6): 2747-2766.

Allen, L. and Gottesman, A. 2006. The informational efficiency of the equity market as compared to the syndicated bank loan market. Journal of Financial Services Research 30:5-42.

Angbazo, L., Mei, J. and Saunders, A. 1998. Credit spreads in the market for highly leveraged transaction loans. Journal of Banking \& Finance 22: 1249-1282.

Ashbaugh-Skaife, H., Collins, D, Kinney, W. 2007. The discovery and reporting of internal control deficiencies prior to SOX-mandated audits. Journal of Accounting and Economics 44, (1-2): 166-192.

Ashbaugh-Skaife, H., Collins, D., Kinney, W., and LaFond, R. 2008. The effect of SOX internal control deficiencies and their remediation on accrual quality. The Accounting Review 83 (1): 217-250.

Ashbaugh-Skaife, H., Collins, D., Kinney, W., and LaFond, R. 2009. The effect of internal control deficiencies on firm risk and cost of equity. Journal of Accounting Research 47 (1): 1-43.

Ball, R., Bushman, R. and Vasvari, F. 2008. The debt-contracting value of accounting information and loan syndication structure. Journal of Accounting Research 46: 247-287.

Bedard, J. 2006. Sarbanes-Oxley internal control requirements and earnings quality. Working paper, http://ssrn.com/abstract=926271.

Beneish, M., Billings, M., and Hodder, L. 2008. Internal Control Deficiencies and information uncertainty. The Accounting Review. forthcoming.

Bharath, S., Pasquariello, P. and Wu, G. 2008. Does asymmetric information drive capital structure decisions? The Review of Financial Studies 22 (8): 3211-3243.

Blokdijk, H., Drieenhuizen, F., Simunic, D., and Stein, M. 2006. An analysis of cross-sectional differences in Big and non-Big public accounting firms' audit programs. Auditing: A Journal of Practice and Theory 25 (1): 27-48.

Botosan, C. 1997. Disclosure level and the cost of equity capital. The Accounting Review 72: 323-349.

Botosan, C. and Plumlee, M. 2002. A re-examination of disclosure level and the expected cost of equity capital. Journal of Accounting Research 40 (1): 21-40. 
Bradley, M. and Roberts, M. 2004. The Structure and Pricing of Corporate Debt Covenants. 6th Annual Texas Finance Festival. Available at SSRN: http://ssrn.com/abstract=585882

Brown, S. and Hillegeist, S. 2007. How disclosure quality affects the level of information asymmetry. Review of Accounting Studies 12: 443-477.

Bryan, S. and Lilien, S. 2005. Characteristics of firms with material weaknesses in internal control: an assessment of section 404 of Sarbanes-Oxley. Available at SSRN: http://ssrn.com/abstract=682363.

Bushee, B., J. Core, W. Guay, and S. Hamm. 2010. The role of the business press as an information intermediary. Journal of Accounting Research 48 (1): 1-20.

Butler, K., and Lang, L. 1991. The forecast accuracy of individual analysts: Evidence of forecast optimism. The Accounting Review, 81 (2): 377-397.

Byington, J. and Christensen, J. 2005. Sox 404: How do you control your internal control? Journal of Corporate Accounting and Finance. May/June: 35-40.

Committee of Sponsoring Organizations of the Treadway Commission (COSO), 1992. Internal control . Integrated framework.

Corless, J. 1972. Assessing prior distributions for applying Bayesian statistics in auditing. The Accounting Review: 556-66

De Franco, G., Guan, Y. and Lu, H. 2005. The wealth change and redistribution effects of Sarbanes-Oxley internal control disclosures. Working paper, http://ssrn.com/abstract=706701.

DeAngelo, L. 1981. Auditor size and audit quality. Journal of Accounting and Economics 3 (3): 183-200.

Dechow, P., Sloan, R. and Sweeney, A. 1996. Causes and consequences of earnings manipulations: An analysis of firms subject to enforcement actions by the SEC. Contemporary Accounting Research 13 (1): 1-36

Desai, H., Hogan, C., and Wilkins, M. 2006. The reputational penalty for aggressive accounting: earnings restatements and management turnover. The Accounting Review 81 (1): 83-112.

Diamond, D. and Verrecchia, R. 1991. Disclosure, liquidity, and the cost of capital. Journal of Finance 46 (4): 1325-1359.

Dichev, I. and Skinner, D. 2002. Large-sample evidence on the debt covenant hypothesis. Journal of Accounting Research 40 (4): 1091-1124. 
Doyle, J., Ge, W., and McVay, S. 2007a. Determinants of weaknesses in internal control over financial reporting. Journal of Accounting and Economics 44: 193-223.

Doyle, J., W. Ge and S. McVay. 2007b. Accruals quality and internal control over financial reporting. The Accounting Review 82: 1141-1170.

Easley, D. and M. O'Hara. 2004. Information and the cost of capital. The Journal of Finance 59 (4): 1553-1583.

Easterwood, J. and Nutt, S. 1999. Inefficiency in Analysts' Earnings Forecasts: Systematic Misreaction or Systematic Optimism? The Journal of Finance 54(5):1777-1797.

Eilifsen, A., and Messier, W. 2000. The incidence and detection of misstatements: A review and integration of archival research. Journal of Accounting Literature 19: 1.43.

Engel, E., Hayes, R. and Wang, X. 2007. The Sarbanes-Oxley Act and firms' going-private decisions. Journal of Accounting and Economics 44: 116-145.

Ettredge, M. , Li, C., and Sun, L. 2006. The impact of SOX 2002 Section 404 internal control quality assessment on audit delay in the SOX 2002 era. Auditing: A Journal of Practice \& Theory 25 (2): 1-23.

Feng, M., C. Li, and S. McVay. 2009. Internal control and management guidance. Journal of Accounting and Economics 48: 190-209.

Fitch Ratings. 2005. Fitch's Approach to Evaluating Management and Auditor Assessments of Internal Control. New York, NY: Fitch.

Francis, J., LaFond, R., Olsson, P., and Schipper, K. 2004. Costs of equity and earnings attributes. The Accounting Review 79: 967-1010.

Francis, J., LaFond, R., Olsson, P., and Schipper, K. 2005. The market pricing of accruals quality. Journal of Accounting and Economics 39: 295-327.

Frankel, R. and Li., X. 2004. Characteristics of a firm's information environment and the information asymmetry between insiders and outsiders. Journal of Accounting and Economics 37: 229-259

Gadanecz, B. 2004. The syndicated loan market: structure, development and implications. BOS Quarterly Review: 75-89.

Gao, P. 2010. Disclosure quality, cost of capital, and investor welfare. The Accounting Review 85 (1): 1-29.

Gaul, L. and Uysal, P. 2009. Do audit fees influence credit risk and asymmetric information problems? Evidence from the syndicated loan market. Working paper available at SSRN. 
Ge, W., and McVay, S. 2005. The disclosure of material weaknesses in internal control after the Sarbanes-Oxley Act. Accounting Horizon 19 (3): 137-158.

Gleason, C., Jenkins, N., and Johnson, W. 2008.The Contagion effects of accounting restatements. The Accounting Review 83 (1): 83-110.

Goh, B. 2009. Audit Committees, Boards of Directors, and Remediation of Material Weaknesses in Internal Control. Contemporary Accounting Research 26 (2): 549-579.

Gupta, P. and Nayar, N. 2006. Information content of control deficiency disclosures under the Sarbanes - Oxley Act: An empirical investigation. International Journal of Disclosure and Governance 4 (1): 3-23.

Hammersley, J., Myers, L. and Shakespeare, C. 2008. Market reactions to the disclosure of Internal Control Deficiencies and to the characteristics of those weaknesses under section 302 of the Sarbanes Oxley Act of 2002. Review of Accounting Studies 13: 141-166.

Haron, H., Ibrahim, D., Jeyaraman, K. and Chye, O. 2010. Determinants of internal control characteristics influencing voluntary and mandatory disclosures: A Malaysian Perspective. Managerial Auditing Journal 25 (2): 140-159.

Harris, M., and Raviv, A. 1991. The Theory of Capital Structure. Journal of Finance 46:297355.

Healy, P., Hutton, A. , and Palepu, K. 1999. Stock performance and intermediation changes surrounding sustained increases in disclosure. Contemporary Accounting Research, 16(3), 485-520.

Hoitash, R., Hoitash, U., and Bédard, J. 2009. Corporate Governance and Internal Control over Financial Reporting: A Comparison of Regulatory Regimes. The Accounting Review 8 (3): 839-867.

Irving, J. II. 2006. The information content of internal controls legislation: Evidence from material weakness disclosures. Unpublished Dissertation, University of North Carolina at Chapel Hill.

Kim, Y. and Park, M. 2009. Market uncertainty and disclosure of internal control deficiencies under the Sarbanes-Oxley Act. Journal of Accounting and Public Policy 28: 419-445.

Kinney, W. 2000. Research opportunities in internal control quality and quality assurance. Auditing: A Journal of Practice and Theory 19: 83-91.

Krishnan, G., Park, M., and Vijayakumar, J. 2008. Does the flight of clients from the Big 4 to second tier auditors indicate lower audit quality? Available at SSRN: http://ssrn.com/abstract=1201782 
Krishnan, J. 2005. Audit committee quality and internal control: an empirical analysis. The Accounting Review 80 (2): 649-675.

Lam, S. and J. Du. 2004. Information asymmetry and estimation risk: Preliminary evidence from Chinese equity markets. Pacific-Basin Finance Journal 12: 311-331.

Lambert, R., C. Leuz, and R. E. Verrecchia. 2007. Accounting information, disclosure, and the cost of capital. Journal of Accounting Research 45 (2): 385-420.

Lang, M., and Lundholm, R. 1996. Corporate disclosure policy and analyst behavior. The Accounting Review, 71(4), 467-492.

Lee, S., and Mullineaux, D. 2004. Monitoring, financial distress, and the structure of commercial lending syndicates, Financial Management 33: 107-130.

Leone, A. 2007. Factors related to internal control disclosure: a discussion of Ashbaugh, Collins, and Kinney (2007) and Doyle, Ge, and McVay (2007). Journal of Accounting and Economics 44: 224-237.

Leuz, C. and Verrecchia, R. 2000. The economic consequences of increased disclosure. Journal of Accounting Research, supplemental (38): 91-124.

Lev, B. 1988. Toward a Theory of Equitable and Efficient Accounting Policy. The Accounting Review 63 (1): 1-22.

LPC web page: http://www.loanpricing.com/analytics/pricing_service_volume1.htm

Mazumdar, S. and P. Sengupta. 2005. Disclosure and the loan spread on private debt. Financial Journal, 61(3), 83-95.

McLaughlin, R., Safieddine, A. and Vasudevan, G. 1998. The information content of corporate offerings of seasoned securities: An empirical analysis. Financial Management 27 (2): $31-45$

Moerman, R. 2008. The role of information asymmetry and financial reporting quality in debt trading: Evidence from the secondary loan market. Journal of Accounting and Economics 46: 240-260.

Moody's Investors Service (Moody’s). 2004. Special Comment: Section 404 Reports on Internal Control. New York, NY: Moody's Investors Service.

Myers, S. 1984. The Capital Structure Puzzle. Journal of Finance 39:575-92.

Myers, S., and N. Majluf. 1984. Corporate Financing and Investment Decisions When Firms Have Information That Investors Do Not Have. Journal of Financial Economics 13:187221. 
Ogneva, M., Subramanyam, K., and Raghunandan, K. 2007. Internal Control Deficiencies and cost of equity: Evidence from SOX Section 404 disclosures. The Accounting Review 82 (5): 1255-1297.

Pae, S. and Yoo, S. 2001. Strategic interaction in auditing: An analysis of auditors' legal liability, internal control system quality, and audit effort. The Accounting Review 76 (3): 333-356.

Press release. 2004. Publication: Business Wire, November 4, 2004.

Public Company Accounting Oversight Board, 2004. Auditing Standard No. 2, An Audit of Internal Control Over Financial Reporting Performed in Conjunction with An Audit of Financial Statements, PCAOB, March 9.

Public Company Accounting Oversight Board, 2007. Auditing Standard No. 5, An Audit of Internal Control Over Financial Reporting That Is Integrated With An audit Of Financial Statements And Related Independence Rule And Conforming Amendments, PCAOB, June 12.

Raghunandan, K. and Rama, D. 2006. SOX Section 404 material weakness disclosures and audit fees. Auditing: A Journal of Practice \& Theory 25: 99:114.

Richardson, S. Teoh, S. and Wysocki, P. 2004. The walk-down to Beatable Analyst Forecasts: The Role of Equity Issuance and Insider Trading Incentives. Contemporary Accounting Research 21(4): 885-924.

Richardson, V. 2000. Information asymmetry and earnings management: Some evidence. Review of Quantitative Finance and Accounting 15: 325-347.

Schrand, C., and Verrecchia, R. 2005. Information Disclosure and Adverse Selection Explanations for IPO Underpricing. Working Paper, University of Pennsylvania.

Sengupta, P. 1998. Corporate disclosure quality and the cost of debt. The Accounting Review 73 (4): 459-474.

Simons, K. 1993. Why do banks syndicate loans? New England Economic Review of the Federal Reserve Bank of Boston, 45-52.

Sufi, A. 2007. Information asymmetry and financing arrangements: Evidence from syndicated loans. The Journal of Finance LXII (2): 629-668.

Teoh, S. and Wong, T. 1993. Perceived auditor quality and the earnings response coefficient. The Accounting Review 68: 346-66.

Turner, J. 2010. Changes in Litigation Risk: An Analysis of Post-Sarbanes Oxley Audit Portfolios. Journal of Forensic and Investigative Accounting 2 (2): 159-228. 
Verrecchia, R. 2001. Essays on disclosure. Journal of Accounting and Economics 32: 97-180.

Welker, M. 1995. Disclosure policy, information asymmetry and liquidity in equity markets. Contemporary Accounting Research, 11(2), 801-827.

Yu, J. 2007. Loan spreads and unexpected earnings. Unpublished Ph.D. Dissertation. The Ohio State University.

$\mathrm{Yu}$, S. and Neter, J. A stochastic model of the internal control system. Journal of Accounting Research 11 (2): 273-295. 


\section{APPENDIX A}

Variables Definition and Measurement

\begin{tabular}{|c|c|c|}
\hline \multirow{2}{*}{$\begin{array}{l}\text { Variable } \\
\text { Information Asymmetry }\end{array}$} & Symbol & Definition \& measurement \\
\hline & IA & $\begin{array}{l}\text { Natural log of the difference between the average annual } \\
\text { bid and ask spread of the traded facility. }\end{array}$ \\
\hline Internal Control Deficiencies & ICDs & $\begin{array}{l}\text { An indicator variable equals } 1 \text { if the firm disclosed } \\
\text { Internal Control Deficiencies, zero otherwise. }\end{array}$ \\
\hline $\begin{array}{l}\text { Internal Control } \\
\text { Weaknesses }\end{array}$ & ICMWs & $\begin{array}{l}\text { An indicator variable }=1 \text { if the firm disclosed ICMWs } \\
\text { under section } 302 \text { or section } 404 \text {, zero otherwise. }\end{array}$ \\
\hline $\begin{array}{l}\text { Internal Control } \\
\text { Weaknesses }\end{array}$ & ICMWs_302 & $\begin{array}{l}\text { An indicator variable }=1 \text { if the firm disclosed ICMWs } \\
\text { under section } 302 \text {, zero otherwise. }\end{array}$ \\
\hline $\begin{array}{l}\text { Internal Control Material } \\
\text { Weaknesses }\end{array}$ & ICMWs_404 & $\begin{array}{l}\text { An indicator variable }=1 \text { if the firm disclosed ICMWs } \\
\text { under section } 404 \text {, zero otherwise. }\end{array}$ \\
\hline Company Level Disclosure & CL & $\begin{array}{l}\text { An indicator variable equal } 1 \text { if the disclosed IC } \\
\text { weaknesses on the company level, zero otherwise. }\end{array}$ \\
\hline Remediation & REM & $\begin{array}{l}\text { An indicator variable }=1 \text { if the firm remediated part or all } \\
\text { the disclosed IC weaknesses in the year } t-1 \text {, zero } \\
\text { otherwise. }\end{array}$ \\
\hline Return on Asset & ROA & $\begin{array}{l}\text { Return on Asset is Income before Extraordinary items / } \\
\text { lagged total assets. }\end{array}$ \\
\hline Total Assets & ASSETS & Natural log of total assets [Compustat data item \# 6]. \\
\hline Market-to-Book ratio & MTB & $\begin{array}{l}\text { Natural log of the ratio of the firm's market value to book } \\
\text { value of common equity, computed as [share price times } \\
\text { the number of shares outstanding [Compustat data item } \\
\# 25 * \text { Compustat data item \#199] divided by [Compustat } \\
\text { data item \# 60]. }\end{array}$ \\
\hline Discretionary Accruals & DA & $\begin{array}{l}\text { We measure the discretionary accruals using the correct } \\
\text { model of the Modified Jones Model as in Dechow, Sloan } \\
\text { and Sweeney (2005). }\end{array}$ \\
\hline Regulated Industry & REG & $\begin{array}{l}\text { An indicator variable }=1 \text { if the firm is in regulated } \\
\text { industry such as financial or utility industry (SIC codes } \\
6000-6999 \text { and } 4900-4999 \text { ), zero otherwise. }\end{array}$ \\
\hline Liquidity & LQ & $\begin{array}{l}\text { Natural } \log \text { of the volume of stock traded to proxy for } \\
\text { liquidity. }\end{array}$ \\
\hline Losses firms & LOSS & $\begin{array}{l}\text { An indicator variable }=1 \text { if the firm had losses over the } \\
\text { last two years [Compustat data item \# 172]. }\end{array}$ \\
\hline Auditor Dismissal & AUD_D & $\begin{array}{l}\text { An indicator variable }=1 \text { if the firm dismissed the auditor, } \\
\text { zero otherwise. }\end{array}$ \\
\hline Auditor Resignation & AUD_R & $\begin{array}{l}\text { An indicator variable }=1 \text { if the auditor resigned, zero } \\
\text { otherwise. }\end{array}$ \\
\hline Big-6 Audit Firms & BIG_6 & $\begin{array}{l}\text { An indicator variable }=1 \text { if the financial statements are } \\
\text { audited by one of the top } 6 \text { audit firms, zero otherwise. }\end{array}$ \\
\hline Short_Revolvers & S_REVOLVERS & $\begin{array}{l}\text { An indicator variable }=1 \text { if it is a short term revolver loan } \\
\text { such as 364-Day Facility, and } 0 \text { otherwise. }\end{array}$ \\
\hline Long_Revolvers & L_REVOLVERS & $\begin{array}{l}\text { An indicator variable }=1 \text { if it is a long term revolver loan } \\
\text { such as Revolver/Line }>=1 \mathrm{Yr} \text {., and } 0 \text { otherwise. }\end{array}$ \\
\hline Bank Lenders & BANK_LENDERS & $\begin{array}{l}\text { An indicator variable }=1 \text { if the identity of the lender is a } \\
\text { bank (Term Loan A "TLA"), and } 0 \text { otherwise. }\end{array}$ \\
\hline Institutional Lenders & INSTIT_LENDERS & $\begin{array}{l}\text { An indicator variable }=1 \text { if the identity of the lender is an } \\
\text { institutional lender (Term Loan B, C, and D), and } 0 \\
\text { otherwise. }\end{array}$ \\
\hline
\end{tabular}




\section{APPENDIX A Concluded}

Variables Definition and Measurement

\begin{tabular}{|c|c|c|}
\hline Variable & Symbol & Definition \& measurement \\
\hline Capital Expenditure Loans & CAP & $\begin{array}{l}\text { An indicator variable }=1 \text { if the loan purpose is to } \\
\text { cover capital expenditures, and } 0 \text { otherwise. }\end{array}$ \\
\hline Corporate-Purpose Loans & CORP & $\begin{array}{l}\text { An indicator variable }=1 \text { if the loan purpose is to } \\
\text { cover corporate expenditures, and } 0 \text { otherwise. }\end{array}$ \\
\hline Commercial Paper Back Up Loans & CP_BACKUP & $\begin{array}{l}\text { An indicator variable }=1 \text { if it is a loan commitment } \\
\text { with a bank "the bank will provide liquidity if the } \\
\text { loan failed", and } 0 \text { otherwise. }\end{array}$ \\
\hline Debt Repay Loans & DEBT & $\begin{array}{l}\text { An indicator variable }=1 \text { if the loan purpose is to } \\
\text { repay debt, and } 0 \text { otherwise. }\end{array}$ \\
\hline Takeover Loans & TAKEOVER & $\begin{array}{l}\text { An indicator variable }=1 \text { if the loan purpose is } \\
\text { takeover, and } 0 \text { otherwise. }\end{array}$ \\
\hline Other Loans & OTHER_LOANS & $\begin{array}{l}\text { An indicator variable }=1 \text { if the loan purpose is any } \\
\text { other reason than the ones listed above, and } 0 \\
\text { otherwise. }\end{array}$ \\
\hline Secured & SECURED & $\begin{array}{l}\text { An indicator variable }=1 \text { if the loan is secured with } \\
\text { collateral, and } 0 \text { otherwise. }\end{array}$ \\
\hline Sponsored & SPONSORED & $\begin{array}{l}\text { An indicator variable }=1 \text { if the loan is for private } \\
\text { equity related-transactions, and } 0 \text { otherwise. }\end{array}$ \\
\hline Credit Rating Categories & RATING_CAT & $\begin{array}{l}\text { A continuous number indicating the rating } \\
\text { categories. }\end{array}$ \\
\hline Syndication & SYND & A continuous number indicating number of lenders. \\
\hline Maturity & MATURITY & $\begin{array}{l}\text { A continuous number indicating the maturity of a } \\
\text { loan or the length of time until the loan is due. }\end{array}$ \\
\hline Loan Size & LOAN_SIZE & Natural log of the loan value in dollar amount. \\
\hline Debt Covenants & COVEN & $\begin{array}{l}\text { An indicator variable }=1 \text { if covenants exist, and } 0 \\
\text { otherwise. }\end{array}$ \\
\hline Sox 404 & SOX 404 & $\begin{array}{l}\text { An indicator variable }=1 \text { if the reporting period } \\
\text { underlying SOX } 404 \text { period, zero otherwise. }\end{array}$ \\
\hline Standard Industry Classification & IND & $\begin{array}{l}\text { Eight indicator variables to represent the different } \\
\text { industries in the sample firms. The SIC two digits } \\
\text { codes are used to categorize the industries. }\end{array}$ \\
\hline
\end{tabular}




\section{Vita}

Ms. Dina F. El-Mahdy was born in Dakahlia Governorate, Egypt on March $1^{\text {st }}$, 1976. She graduated with a B.Com. degree in Accounting with an Honor distinction in 1997 from Cairo University as well as a Master degree in Accounting and Finance in 2004 from the same institution. Ms. El-Mahdy moved to the USA in 2005 and then pursued her Ph.D. degree in August 2007, with a major in Accounting and a minor in Finance, from Virginia Commonwealth University. Ms. El-Mahdy has more than 14 years of teaching and research experience in accounting and scholarly research. She has published a book chapter in an edited book titled: Focus on Finance and Accounting Research in 2006 as well as co-authored a book on corporate Governance in 2010 with Prof. Carolyn Strand Norman, the book title is: Corporate Governance and the U.S. Firm: A Review and Directions for Future Research. Ms. El-Mahdy has an active research agenda and was awarded the 2010 Best PhD Candidate Paper Award from the American Accounting Association Southeast Regional Meeting for her paper titled: Earnings Management and Information Asymmetry in the Secondary Loan Market. Ms. El-Mahdy is the Units and Coordinator Officer in the Egyptian Student Association in North America, a not-for-profit registered organization in the U.S.A., and the Treasurer of the Graduate Student Association at Virginia Commonwealth University. Ms. El-Mahdy was awarded 2009 and 2011 Who's Who Among Students in American Universities and Colleges, one of the most prestigious awards the academic community can bestow, in recognition of her academic excellence and outstanding service to community. Ms. El-Mahdy has accepted a full time position as an Assistant Professor of Accounting at Morgan State University to begin in August, 2011. 